\title{
THE URBAN TRANSPORTATION PROBLEM
}

\author{
Gilbert Paul Verbit $\dagger$
}

TABLE OF CONTENTS

I. INTRODUCTION ................................................. 369

II. Three Views of the Problem ............................. 372

A. The Transportation Disadvantaged ....................... 372

1. The Young ............................................... 373

2. The Elderly .............................................. 373

3. The Handicapped ................................... 377

4. The Poor ...................................................... 378

5. Summary .............................................. 388

B. Congestion .................................................... 388

C. The Automobile Commuter ................................ 390

III. System Costs of Automobile Commuting ........... 392

A. The Automobile as an Energy Water ................... 392

B. The Automobile as a Polluter .............................. 394

C. The Automobile as a Tortfeasor ........................... 397

D. The Automobile as a Space Waster ...................... 398

IV. The Urban Mass Transportation Act of 1964 .. 401

A. The Act's Preference for Rail Rapid Transit ......... 401

B. The Basis for the Act's Preference for Rail Rapid

Transit ............................................................. 412

1. Potential Benefits Examined ...................... 413

a. Cost ...................................................... 413

b. Speed ........................................................ 414

c. Labor Savings ........................................... 416

d. Diversion of Automobile Traffic .................. 417

2. The Argument for Rail Rapid Transit Rebutted

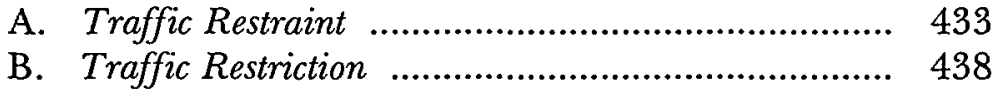

† Professor of Law, Boston University. B.S. 1957, University of Pennsylvania; LL.B. 1960, Yale University. Member, District of Columbia and Massachusetts Bars. 
VII. Street Use Planning ........................................... 445

A. The Power to Restructure Street Use ..................... 446

1. Delegation of Authority from State to $\mathrm{Mu}$ nicipality

2. The Validity of Restructuring Street Use ... 449

B. The Abutter's Rights .......................................... 454

1. The Right of Access and Compensation ..... 456

2. Abutters' Rights and Street Use PlanningSpecial Problems

a. The "Piazza" Principle .............................. 468

b. "Squeezing" ........................................... 470

c. Leveling ............................................... 470

C. Vacation ........................................................... 472

1. Vacation Defined ...................................... 473

2. Procedural Problems ................................. 475

3. Problems of Reversion and Compensation . 479

D. Special Benefits ................................................. 482

VIII. ConCLUSION ............................................................. 487

\section{INTRODUCTION}

The Urban Mass Transportation Act of $1964^{1}$ is the framework of the legislatively determined solution to the urban transportation problem. In accordance with that solution, billions of dollars of public money have been expended and billions more will be. ${ }^{2}$ The purpose of this Article is to examine the Act and the solution embodied therein critically.

The analysis will begin with an attempt to identify the problem, which is by no means self-evident. In particular, discussion will focus on the three aspects of the problem embodied in the Act. The first of these is the plight of the "transportation disadvantaged"- those who lack access to an automobile in an age when such access is a prerequisite to minimum mobility. The second facet of the urban transportation problem to be discussed is "congestion." Astronomic sums have been expended to relieve traffic congestion in urban areas but the solution continues to elude us. Champions of the Act believe strongly that it will at long last lead to elimination of the congestion problem. Finally,

149 U.S.C. $\S \S 1601-12$ (1970).

${ }^{2}$ See text accompanying notes $158-180$ infra. 
we shall examine the automobile "journey to work" as an urban transportation problem. The analysis will lead to the conclusion that the journey to work is the urban transportation problem. Upon examination, the issue of the "transportation disadvantaged" shrinks to a size that is virtually de minimus and even this residuum appears to present an issue of public transportation though not of mass transportation. And "congestion" will be seen to be more a solution than a problem.

The automobile journey to work is the urban mass transportation problem because it is the only category of transportation for which mass transportation is a viable alternative. Before discussing how drivers and passengers might be shifted from automobiles to mass transportation vehicles, however, it is necessary to examine why this need be done. Thus the Article will analyze the social costs of automobile commuting and, in particular, the social evils of pollution, energy waste, accidents, and misallocation of urban land. Although the verdict here will be "not proven," the Article will proceed on the generally accepted assumption that society will benefit from the diversion of traffic from automobiles to mass transportation. The issue, then, is how to achieve this end.

The heart of the Urban Mass Transportation Act and the channel into which most of its vast resources have been poured is the idea that a sufficient number of commuters will be lured from their automobiles by the improvement of existing mass transportation systems and the construction of new systems. It will be argued that this thesis is at best wishful thinking and that it is destined to fail in terms of its stated goal.

The Act will be examined a priori in the light of studies indicating why commuters prefer automobiles to mass transit vehicles. The negative conclusions about the Act that flow from this analysis will be bolstered by data indicating exceedingly low diversion figures, and even lower figures for the decline in automobile trips to work, when commuters are offered modern mass transportation. It will be concluded that the Act fundamentally misconceives the urban transportation problem as a technological one when in fact the problem is behavioral.

Assuming that the urban transportation problem is one of commuter behavior, various systems that purport to affect commuter behavior will be explored. Systems that attempt to induce commuters to use mass transportation will be disposed of quickly and discussion will focus on barriers to automobile commuting, 
which are grouped into traffic restraint and traffic restriction systems. While some of these systems are effective in discouraging automobile commuting, they share with the Act a common defect: Like the Act they treat transportation as an end in itself instead of as a means of moving between two fixed points. In particular, neither the solutions encompassed by the Act nor systems that discourage automobile commuting improve the attractiveness of the urban area as a workplace. In fact, the mass transportation "improvements" envisaged by the Act may affect the urban environment as negatively as the now-rejected urban highways. The auto commuter may love his car more than his job; if so, the trend toward living and working in the suburbs will accelerate.

The optimal solution to the urban transportation problem, therefore, would discourage automobile commuting and would act to improve the attractiveness of the urban area. Such a solution can be found if one reconceives the urban transportation problem as a land planning problem. Present planning has allocated up to twenty-five percent of all urban land for use as a "street,"3 without making any more sophisticated judgments about a street's use. Streets are subject to the demands of a variety of competing uses just as is the land abutting those streets. While use categorization for the latter areas began with the classic triumvirate-industrial, commercial, and residential -and has since been refined ad infinitum, streets have, with rare exceptions, remained streets. The failure to recognize the possibility of competing street uses has permitted the bad mode of transportation (private automobiles) to drive the good mode (mass transportation) from the streets.

The present task, then, is to right the balance by adopting a system of zoning streets for particular categories of use with a view toward discouraging automobile commuting and improving the attractiveness of the urban area. Implementing this solution will require mastery of a complex body of real property law. The legal principles involved will be examined in Part VII of this Article. This Article thus represents an attempt to accept the invitations extended by planners such as Jane Jacobs, Victor

${ }^{3}$ See J. Meyer, J. Kain \& M. Wohl, The Urban Transportation Problem 311 (1965) [hereinafter cited as Meyer]. See also W. Owen, The Accessible City 95 (1972): "The space devoted to streets usually represents the largest portion of publicly owned urban land." 
Gruen, and John Meyer, all of whom have indicated that the ultimate solution to the urban transportation problem lies at least partially within the expertise of lawyers. ${ }^{4}$

\section{Three Views of the Problem}

\section{A. The Transportation Disadvantaged}

In arguing for passage of the Act, then Secretary of Housing and Urban Development Weaver noted that

there is a tremendous number of our population that cannot avail themselves of automobiles. I speak of the aged; I speak of those who are incapacitated, either permanently or temporarily; I speak of the young people who are too young to drive; and I speak of those who cannot afford and do not afford an automobile . . . .5

Although not identified in the legislation, this constituency has been labeled by administrative practice as the "transportation disadvantaged." Persons who "cannot avail themselves of automobiles" are estimated to be $15 \%$ of the residents of each Standard Metropolitan Statistical Area (SMSA). ${ }^{7}$ In absolute

"It has been suggested, e.g., MEYER, supra note 3, at 331-32, that "adaptation" of "cities and CBD's [central business districts] to transportation technology . . . may be the only satisfactory solution" and that "the challenges of reorganizing CBD's in this way (to achieve 'appropriate' urban land use) may be as much legal and institutional as technological." See also Meyer, Urban Transportation, in THE Metropolitan ENIGMa 57 (J. Wilson ed. 1970). "A better longer-term solution may be, however, in adjusting the physical layouts of those older business areas to modern technological circumstances ... [via] urban renewal." Id. 66. The connection between land use, transportation controls, and environmental quality has been identified in $\$ 110(a)(2)(B)$ of the Clean Air Act, 42 U.S.C. § $1857 \mathrm{c}-5(\mathrm{a})(2)(\mathrm{B})(1970)$.

${ }^{5}$ Hearings on Urban Mass Transportation Act Before the Senate Comm. on Banking and Currency, 88th Cong., Ist Sess. 71 (1963).

' Urban Mass Transportation Administration, U.S. Dep't of Transportation, External Operating Manual IIA-2 (1972) [hereinafter cited as Manual]. See also Villarreal, Meeting the Needs of the Transit Dependent, Highway \& Urban Mass Transp. 32 (1972); C. Villarreal, Opportunities for the Transit Dependent, Conference on Transportation and Human Needs in the '70's (Am. U.), June 19, 1972, at 50, 54-55. More recently, the Department of Transportation extended the definition of the "transportation poor" to include "in some circumstances even the one-car family." U.S. DEP'T OF Transportation, State-of-the-Art Overview, Demand-Response Transportation 1 (1974). See also Editorial, Metropolitan, Jan.-Feb., 1975, at 14.

For another definition, see Kinley, Resource Paper on the Transportation Disadvantaged, in Urban Travel Demand Forecasting 121, 123 (Highway Research Bd. Special Rep. No. 143, 1973): "An individual (or group) is transportation disadvantaged . . if he takes significantly fewer trips, for any purpose, or has significantly longer travel times than would be expected for his income."

${ }^{7}$ See Kinley, supra note 6, at 124. 
numbers, estimates range from 50 million to 103.9 million. $^{8}$ While the definition of "availability" inevitably leaves some uncertainty in determining the size of the relevant population, a somewhat more accurate figure hinting at similar dimensions of the problem is the percentage of households not owning an automobile. For the major SMSA's, the 1970 census figure was $20.4 \%$. For Los Angeles the figure was $17.2 \%$; Philadelphia, $27 \%$; and Chicago, $28.3 \% .^{9}$

\section{The Young}

The largest group of the transportation disadvantaged is the young-the $38 \%$ of the population under twenty years old. Since only $4 \%$ of this group are licensed drivers, the young are identified as transportation disadvantaged. Yet persons under twenty account for only $7 \%$ of all transit passengers. This would seem to indicate that (a) the young make fewer trips than the population in general, (b) more of their trips are made by walking or cycling, and/or (c) considering that $20 \%$ of American families own two cars, most of the transportation needs of the young are satisfied by parents' chauffeuring. ${ }^{10}$ All three conclusions are probably valid. In addition, estimates indicate that more than half the trips made by persons under sixteen are to and from school, and these trips are generally satisfied by school bus service. ${ }^{11}$

\section{The Elderly}

The next largest group included in the transportation disadvantaged category is the elderly, those over sixty-five years of

${ }^{8}$ Compare Villarreal, supra note 6 , at 32 , with J. Crain, Transportation Problems of Transit Dependent Persons-A Status Report, Conference on Transportation and Human Needs in the '70's (Am. U.), June 19, 1972, at 3-4.

If one includes persons in households with one car, which is used for journey to work, the total number of persons who "have no immediate access to a car" is $132,800,000$, or $65 \%$ of the American population. Paaswell \& Recker, Location of the Carless, in Transportation for the Poor, the Eiderly, and the Disadvantaged 11,13 (Transp. Research Record No. 516, 1974) [hereinafter cited as TRANSPORTATION FOR THE POoR].

9 See Office of Systems Analysis \& Information, U.S. Dep't of Transportation, Economic Characteristics of the Urban Public Transportation Industry 1-5 (1972) [hereinafter cited as Economic Characteristics].

${ }_{10} \mathrm{M}$. Wohl, Users of Urban Transportation Services and Their Income Circumstances, Conference on Poverty and Transportation (Am. Academy of Arts \& Sciences), June 7,1968 , at 7 .

${ }^{11}$ See Curry, Providing Transportation for Persons with Limited Mobility in Suburban Areas, 
age. This group comprises roughly $10 \%$ of the population ${ }^{12}$ and in 1970 had a median age of seventy-three. ${ }^{13}$ Like the young, the elderly as a group contains a disproportionately small number of licensed drivers and automobile owners. ${ }^{14}$ Unlike the case of the young, however, it is difficult to assume that the elderly are members of households that own automobiles to which they have access as drivers or passengers. They are more clearly transportation disadvantaged within the meaning of the definition. In thinking about how their situation might be improved, however, the inadequacy of the definition becomes clear: If being transportation disadvantaged means lacking access to an automobile, the availability of an alternative transportation mode cannot change that status. Only providing access to an automobile could do that. It becomes necessary to add an additional element to the definition of transportation disadvantaged-Secretary Weaver's lack of automobile availability plus some loss associated with this lack. If the elderly have a transportation problem, it is not only that they lack access to an automobile but that this lack of access deprives them of the opportunity to do something they want or need to do. ${ }^{15}$

Studies of the mobility patterns of older people in San Antonio and New York have indicated a generally low frequency of

in Transit for the Poor, the Aged, and the Disadvantaged 47 (Highway Research Record No. 403, 1972) [hereinafter cited as TRAnsit For THE Poor].

${ }^{12}$ Urban Mass Transportation administration, U.S. Dep't of Transportation,

The Handicapped and Elderly Market for URban Mass Transit 5, 9 (1973) (9.3\% of urban 1970 census) [hereinafter cited as UMTA]. See also Kinley, supra note 6, at 125 (12.8 million persons in SMSA's over 65 according to 1970 census).

${ }^{13}$ Brotman, The Elderly As A Significant Population Group, in Transportation and Aging 10, 11 (E. Cantilli \& J. Shmelzer eds. 1970) [hereinafter cited as Transportation AND AGING].

${ }^{14}$ Only 56\% of households headed by an elderly person own an automobile, compared with a national average of $80 \%$. Carp, The Mobility of Retired People, in Transportation and Aging, supra note 13, at 23, 24 (citing Brotman, supra note 15). Census figures for Chicago in 1960 indicated an average auto availability of $60.1 \%$ of all occupied housing units versus $23.4 \%$ for the elderly. Shmelzer, Elderly Ridership and Reduced Transit Fares: The Chicago Experience, in TRANSPORTATION AND AGING, supra note 13 , at 123,128 . Moreover only $24 \%$ of the elderly are licensed drivers, compared with a figure of $54 \%$ for the total population sixteen and over. Markovitz, The Transportation Needs of the Elderly, in Transportation and AGING, supra note 13, at 67, 68.

${ }^{15}$ In the transportation field the term "latent demand" is sometimes used to "identify those trips which the population needs to take or would like to take, but which are presently not taken because the service is not available or accessible." This definition assumes a readiness to pay the price for such service-an assumption not clearly justified in the case of the aging. Thus it is probably more useful to talk about "unfulfilled needs." Kinley, Latent Travel Demand of the Aging and Handicapped and Barriers to Travel, in Transportation and AgING, supra note 13, at 52. 
trips made by the elderly. ${ }^{16}$ The lower trip rates for the elderly in the San Antonio and New York studies could be a function of the aging process or could be evidence of a lack of available transportation. While neither study collected data directly on point, it is interesting to note that at the highest income stratum of the New York study (household income of $\$ 10,000$ and above, where one can safely surmise adequate access to some form of public or private transportation), the daily trip rate for the elderly, excluding trips to and from work, was .44 while the average for the entire population at that income level was $.83 .^{17}$ These figures suggest that the elderly travel less partly because their needs are fewer and their desire to travel is less.

The elderly may travel less because they constitute a significant portion of two other groups who travel less--the poor and the handicapped. ${ }^{18}$ The transportation problems of the poor $^{19}$ apply equally to the elderly poor. Moreover, because the process of aging involves physical deterioration, the elderly would seem to be deprived of transportation not so much because of age but because of the physical handicaps associated with age. This raises the general question whether age really is a relevant category or whether it is a surrogate for other factors affecting travel. ${ }^{20}$

${ }^{16}$ In the San Antonio study, median responses for the following types of trips were: to visit friends, once a month; to visit children, once a year; to visit relatives, once a year; to visit the doctor, several times a year; grocery shopping, weekly; other shopping, several times a year; church, 2-3 times a month. Carp, supra note 14, at 35 . This "homeboundness" was also manifested in a study in the Tri-State Region (New York Metropolitan area) where at all income and density levels the daily trip rate per person, excluding trips to and from work, was .59 , while the trip rate for the elderly was only .32 . Markovitz, supra note 14 , at 71 .

${ }_{17}$ Markovitz, supra note 14 , at 71.

${ }^{18}$ See generally Libow, Older People's Medical and Physiological Characteristics: Some Implications for Transportation, in TRANSPORTATION AND AGING, supra note 13, at 14, 16. The elderly comprise $10 \%$ of the general population but $18 \%$ of households with incomes below the poverty line. Looked at in another way, only $11 \%$ of the general population are poor, while $25 \%$ of the elderly are poor. Brotman, supra note 13. But see UMTA, supra note 12, at 10 (1970 census indicates per capita income of persons over 65 higher than under 65). Relying again on the Tri-State Transportation Commission data, the trip rate for the elderly in households with a 1963 income of $\$ 0-2,999$ was .24 , while the figure for the $\$ 10,000$-and-above income level was .44. Markovitz, supra note 14 , at 71 .

19 See generally text accompanying notes 33-71 infra.

${ }^{20}$ For the "surrogate" view, see Garrison, Limitations and Constraints of Existing Transportation Systems as Applied to the Elderly, in Transportation and Aging, supra note 13, at 100, 103. But of. Senate Special Comm. on Aging, Developments in Aging 1969, S. Rep. No. 875, 91st Cong., 2d Sess. 91, 101 (1970). See also Older Americans Comprehensive Services Amendments of 1973, § 401, 42 U.S.C. § 3035a (Supp. 1973). The Administration did not request funding for this provision in its fiscal 1974 budget. See Hearings Before Senate Special Comm. on Aging, 93d Cong., 2d Sess. 79 (1974). 
A current program illustrating this confusion of categories and goals is the reduced transit fare for "senior citizens" during off-peak hours. On July 1, 1969, New York City initiated a plan whereby senior citizens could use public transit at half fare from 10:00 a.m. to 4:00 p.m. and from 7:00 p.m. to midnight, as well as all day on Saturdays, Sundays, and holidays. Of the total population estimated to be eligible, almost $60 \%$ registered for their "New York City Reduced Fare Card."21 A similar half fare plan was instituted in Chicago on April 20, 1969. ${ }^{22}$ These programs could increase transit opportunities for the elderly only through the lower $\operatorname{cost}^{23}$-an appeal directed not to the elderly but to the elderly poor. One must therefore ask whether the programs would not be more rational if they offered decreased fares to the poor. ${ }^{24}$ Moreover, a significant percentage of the

\footnotetext{
21 Surveys taken one year after the program was initiated (and compared with similar pre-program surveys) indicate an increase of $26.7 \%$ elderly riders between 10:00 a.m. and 4:00 p.m. Because the largest increment occurred between 12:00 p.m. and 2:00 p.m., it has been suggested that the increment represents a genuine increase in traffic as opposed to a shift from peak to non-peak travel. Cantor, The Reduced Fare Program for Older New Yorkers: Some Effects and Implications of the First Year of Operations, in Transportation AND Aging, supra note 13, at 114, 117-22.

22 A before-and-after study was completed in January 1970. The study consisted of three parts. A sample of elderly "trip diaries" during the periods March 22-April 4 (pre-experiment) and August 4-17, 1969, indicated an increase of $86 \%$ in the number of Chicago Transit Authority (CTA) trips taken by senior citizens during the plan hours of 9:00 a.m. to 3:00 p.m. A second part of the data collection consisted of a sub-sample of the larger group who reported both "Before and After." Here again a $62 \%$ increase in ridership on CTA modes was evidenced, against a general decline in all modes. Finally, On-Board-Bus ridership surveys were conducted during the weeks of April 1-7, 1969, August 5-11, 1969, and January 20-26, 1970. Because only three bus routes remained the same over time, the results were insufficient for aggregation. As to the routes themselves, the first showed an increase of $36.8 \%$ in the number of senior citizen riders from April to August, the second an increase of $34.2 \%$, and the third an increase of $43.1 \%$. The period from August to January, however, evidenced substantial declines in usage so that the overall increases from April to January were a more modest $9.1 \%, 17.8 \%$, and $-1.96 \%$, respectively. Presumably, similar declines would have been evidenced in the samples under parts one and two if they had been carried on until January. Moreover, percentages on small bases tend to be misleading. The $9.1 \%$ increase for the first line represented an increase in the number of senior citizen passengers from 17.4 to 19 per hour. The $17.8 \%$ increase represented an increase of less than one senior citizen passenger per hour. These modest results are strengthened, however, by "some evidence to indicate that general passenger revenues had been declining for a part of the period during which this study was underway." Shmelzer, supra note 14 , at 123, 128-31.

${ }^{23}$ The irony of these programs is that "transit fares are more important in mode choice for the work trip than for other purposes ...." McGillivray, Binary Choice of Urban Transport Mode in the San Francisco Bay Region, 40 EconomerRICA 827, 847-48 (1972).

${ }^{24}$ In a survey to determine the transportation needs and desires of the elderly in Champaign, Illinois, not one respondent in over two hundred elderly interviewees mentioned cost as a reason for not using the bus. Weaver \& Herrin, Transportation Needs and Desires of the Elderly Residing in a Medium-Sized City, in TRANSPORTATION FOR THE POOR, supra note 8 , at $28,32$.
} 
increased elderly traffic during off-peak hours may have been diverted from peak hour travel and thus may not represent an increase in transit opportunities for the elderly. ${ }^{25}$ These programs seem designed less to solve the transportation problems of the elderly than to assist the transit authorities in leveling out demand for transit facilities. Given the infrequent service characteristic of non-peak periods, the elderly may be worse off under these programs because their trips may now take longer. Although travel time is a critical factor in urban transportation trips, it is least critical for the elderly. ${ }^{26}$

\section{The Handicapped}

The Department of Transportation has indicated that for present purposes, "a handicap is an inability to perform one or more of the actions required by existing transportation systems at a comfortable level of proficiency."27 A 1973 Department of Transportation (DOT) study estimated the number of transit handicapped at $13,390,000 .{ }^{28}$ Of this number it was estimated that $38 \%(5,088,200)$ live in "transit-oriented" urban areas. ${ }^{29}$ Another $41 \%(5,489,900)$ live in auto-oriented urban areas and $21 \%(2,811,900)$ reside in rural areas. ${ }^{30}$ Of the total handicapped, 6,990,000 are sixty-five or older and 6,400,000 are under sixty-five. ${ }^{31}$

In considering the problems of the transportation handicapped, a shifting of definitional criteria becomes apparent. While Secretary Weaver described the problem of the transpor-

${ }^{25}$ A Pittsburgh study indicated that a reduced fare program increased monthly round trips by elderly riders $10.5 \%$ in Allegheny County. There was also a diversion of $34.3 \%$ from peak to off-peak periods. See Hoel \& Roszner, Impact of Reduced Transit Fares for the Elderly, 26 TRAFFiC Q. 341, 352, 356 (1972).

${ }^{26}$ See generally Carp, supra note 14, at 28; Golob, Canty, Gufstafson \& Vitt, $A n$ Analysis of Consumer Preferences for a Public Transportation System, 6 TRANSP. ReSEARCH 81, 91, 98 (1972) [hereinafter cited as Golob].

Despite the questionable benefit of nonpeak half-fare plans, their adoption for the elderly has become a condition of federal assistance. National Mass Transportation Assistance Act of 1974, § 5(m), 49 U.S.C.A. § 1604(m) (Supp. Feb. 1975).

${ }^{27}$ Office of the Secretary, U.S. Dep't of Transportation, Travel Barriers 4-5 (1970) [hereinafter cited as TRAVEL BARRIERS].

${ }^{28}$ See UMTA, supra note 12, at 7. M. Biaggi, Legislation for Transit Dependent Groups, Conference on Transportation and Human Needs in the '70's (Am. U.), June 19,1972 , at 152,155 , estimates the number to be "forty million."

${ }^{29}$ Transit-oriented areas are characterized by more than $8 \%$ transit usage for work trips. There are 43 such areas, including $87 \%$ of American transit usage. See UMTA, supra note 12 , at 7 .

${ }^{30} I d$.

${ }^{31}$ Id. 8. 
tation disadvantaged as lack of automobile availability, the criteria for inclusion among the transportation handicapped fail to mention automobiles. Although it could be argued that the phrase "existing transportation systems" includes automobile transportation, a subsequent DOT definition specifically defines the type of handicap as an inability to "utilize mass transportation facilities and services." ${ }^{32}$ As in the case of the elderly, one must ask why this is a problem. Specifically, the inability to utilize mass transportation facilities because of a physical handicap is a problem only if alternative modes of transportation such as automobiles are not available and this unavailability prevents the handicapped from making trips they need or want to make. But even the sketchy data on trip frequencies and auto availability for the elderly are lacking for the handicapped. The DOT definition evidences less concern for the transportation problems of the handicapped than an institutional concern for mass transportation.

\section{The Poor}

Because the elderly are generally beyond the years of gainful employment and because the handicapped are disadvantaged in employment, both form large subgroups of the broader category of the poor. Again, if to be transportation disadvantaged is to be without access to an automobile, the poor constitute the largest identifiable group of transportation disadvantaged. ${ }^{33}$

3243 U.S.C. $\S 16($ d) (1970); UMTA, supra note 12, at 2: “[A] transit-relevant, 'physically handicapped' person is any individual who, by reason of illness, injury, age, congenital malfunction, or other permanent or temporary incapacity or disability, is unable without special facilities or special planning or design to utilize mass transportation facilities and services as effectively as persons who are not so affected." The average percentage of non-institutionalized handicapped persons aged sixteen to sixty-four in urban areas, according to the 1970 census, was 5.5. Id. 5 .

${ }^{33}$ An estimated $80 \%$ of all households own an automobile. The ownership figures for low income groups are as follows: $\$ 2,000-\$ 2,999$ pre-tax income, 52\%; $\$ 1,000-\$ 1,999,38 \%$; below $\$ 1,000,25 \%$. J. Meyer \& J. Kain, Interrelationships of Transportation and Poverty: Summary of Conference on Transportation and Poverty (Am. Academy of Arts \& Sciences), June 7, 1968, at 5 (citing Motor Vehicle Manufacturers Association, 1968 Automobile Facts and Figures 44). The lowest income breakdown in Motor Vehicle Manufacturers Association, 1975 Automobile FACTS AND FIGURES 32 , is "under $\$ 3000$." In that category, $45.3 \%$ of households were owners.

A 1968 survey in Watts indicated that only 246 of 530 males seeking employment had "access" to an automobile. Only 200 of these automobiles were safe for use on freeways, and only 153 were insured. T. Floyd, Using Transportation to Alleviate Poverty: A Progress Report on Experiments Under the Urban Mass Transportation Act, 
Assuming the general validity of the data, does the lack of availability of automobile transportation prevent the poor from taking trips? The poor appear to make fewer trips than the general population, ${ }^{34}$ though travel studies do not generally include trips made by walking except for walk-to-work trips. It may well be that the poor do take as many trips but in traveling for shopping or social purposes walk more than the general population. ${ }^{35}$ Moreover, the fact that the poor take fewer vehicular trips could be the result of relative ignorance about the availability of transit, ${ }^{36}$ a lack of knowledge of opportunities, ${ }^{37}$ or a lack of the wherewithal to spend at a trip site. ${ }^{38}$ (One does not travel to the cinema, for example, if one hasn't the price of a ticket.) On the other hand, the relative lack of mobility of the poor may be because they are "transportation disadvantaged."

Lack of access to suburban job opportunities is alleged to be the principal transportation disadvantage of the poor. ${ }^{39}$ That new employment opportunities are developing more rapidly in the suburbs than in the central cities is established. ${ }^{40}$ Nor is there much argument about the fact that existing systems of public

Conference on Poverty and Transportation (Am. Academy of Arts \& Sciences), June 7, 1968 , at 9 .

${ }^{34}$ A study using data from the 1963-1965 Boston Regional Planning Project indicated that the deficit exists chiefly with regard to work trips. See P. Herr \& A. Fleisher, The Mobility of the Poor, Conference on Poverty and Transportation (Am. Academy of Arts \& Sciences), June 7, 1968, at 11 . In the $\$ 0-3999$ income bracket work trips were $11.7 \%$ of all trips for the non-auto owner, $12.6 \%$ of all trips for the owner, and $12.3 \%$ for all respondents in this bracket. The average for all respondents was $18.4 \%$. See id. (Table 2).

${ }^{35}$ Transcript, First Session, Conference on Poverty and Transportation (Am. Academy of Arts \& Sciences), June 7, 1968, at 13 (remarks of Kain) [hereinafter cited as Transcript, 1st Sess.]; Falcocchio, Pignataro \& Cantilli, Modal Choices and Travel Attributes of Inner-City Poor, in Transit for THE Poor, supra note 11 , at 6,11 .

${ }^{36}$ See, e.g., Transcript, Second Session, Conference on Poverty and Transportation (Am. Academy of Arts \& Sciences), June 7, 1968, at 37-38 (remarks of Brandwein) [hereinafter cited as Transcript, 2d Sess.].

${ }^{37}$ P. Herr \& A. Fleisher, supra note 34, at 11.

${ }^{38} \mathrm{Id}$.

${ }^{39}$ See, e.g., J. Crain, supra note 8 , at 6.

${ }^{40}$ In 1960 the job location split for the fifteen largest metropolitan areas was twothirds in the central business districts and one-third in the suburbs. By 1970 the number of jobs in the suburbs had increased by $44 \%$ while the number in the central cities had decreased by $7 \%$. Thus in 1970 the central cities had only $52 \%$ of total metropolitan area jobs. See Bureau of the Census, General Social and Economic Characteristics, 1970 Census of Population.

The center city is "tending more and more to specialize in control, consultation, and communication functions-in activities that require chiefly professional, technical, and highly trained clerical workers." E. Kalachek, Ghetto Dwellers, Transportation and Employment, Conference on Poverty and Transportation (Am. Academy of Arts \& Sciences), June 7,1968 , at 3. 
transportation developed according to a radial trip pattern, oriented toward bringing the suburban resident to his central city workplace. The urban ghetto dweller needs what has been termed an inside-out system which would move him from his central city residence to his suburban workplace. ${ }^{41}$ Note that this is not "reverse commutation": existing transit facilities serve mainly suburban residential areas and do not provide access to job sites in the suburbs. That these intuitive observations reflect reality received support in the statement of the McCone Commission Report on the 1965 Watts riots:

Our investigation has brought into clear focus the fact that the inadequate and costly public transportation currently existing throughout the Los Angeles area seriously restricts the residents of the disadvantaged areas such as south central Los Angeles. This lack of adequate transportation handicaps them in seeking and holding jobs, attending schools, shopping and fulfilling other needs. ${ }^{42}$

The difficulty with the existing data is that it may not be relevant to the problem under consideration. The expense in time and money of traveling from the central city to the suburbs is relevant only if suburban jobs are part of the job market for city residents. To take an absurd example for purposes of illustration, if one is a resident of New York possessing skills for

${ }^{41}$ See Meyer, supra note 4, at 72.

42 Governor's Commission on the Los Angeles Rrots, Violence in the City-AN END OR a Beginning 65 (1965). See Haar, Transportation and Economic Opportunity, 21 Traffic Q. 521, 522 (1967).

Specifically, for a Watts resident to travel the seventeen miles to a job at Douglas Aircraft in Santa Monica required five vehicle changes, cost $83 \epsilon$, and consumed an hour and thirty-eight minutes each way. The nine-mile trip from Watts to jobs at the Harbor General Hospital required an hour and cost $75 \ell$ each way. Moreover, there was no bus service between 11:15 p.m. and 7:00 a.m. A similar situation was documented in St. Louis, where a central city resident had to spend one to two hours and a minimum of $75 \mathrm{f}$ each way to reach the Hazelwood Industrial area.

A related but more general argument utilizing the same facts runs as follows: The emphasis on road construction in the 1950's and 1960's encouraged, indeed caused, decentralization of the central city population and particularly employment. Adequate public transit, it is argued, would reverse this trend. Figures plotting percentage changes in central city employment and population against transit use indicate, however, that the decline in employment and population was greatest in cities where the percentage of central city workers who used public transit was highest. Center city decline was closely correlated with the age of the city (a figure that coincided with highest transit use) and the consequent unavailability of vacant land. While not negating transit as a factor in land use, the figures seem to refute claims that transit is decisive. MEYER, supra note 3, at 44-47. 
which there is no demand in New York but a great demand in Chicago, and prefers to remain a resident of New York, is he transportation disadvantaged because air service between New York and Chicago is so infrequent or expensive that it is not possible for him to commute to Chicago on a daily basis? In short, what is the relevant job market for this person and for the city resident? The usual definition of the job market is based on some tolerable commuting time; the generally accepted norm in the United States is about a half hour. If we depart from this usual definition and redefine the relevant job market to be any area in which there are attractive jobs for which one is qualified, we have created a transportation problem by definition.

The way out of this circularity is to identify the relevant job market as an area whose perimeter can be reached by normally available means of transportation within some agreed-upon time, "normally available" referring to technology as opposed to availability in fact. This definition is useful in illustrating the real nature of the transportation barrier to employment that may be faced by the poor. A study of job opportunities for low-income workers based on 1963-65 data in Boston indicated that a forty-minute transit trip from Boston's South End provided access to 159,500 moderate income jobs while commuting by auto for forty minutes opened up 272,700 jobs. ${ }^{43}$ The object is, therefore, incremental improvement by increasing the number of jobs available by transportation improvements within an acceptable time frame.

This analysis implies that if job opportunities exist only beyond the perimeter set by a reasonable time frame and reasonable transportation improvements, the problem is not one of transportation at all. In illustrating the definition of the relevant job market, we considered the case of a resident of New York wishing to commute to Chicago. Except in unusual circumstances, such a situation is unrealistic. Usually, employees move to where the jobs are. The Watts resident who could endure the arduous trip to Douglas Aircraft, if he survived the probationary period, might reasonably be expected to find a residence nearer his work site. If he were white he could and would. A study of mobility patterns of the low-income white worker in New York, for example, indicates that he "invariably is able to move his

${ }^{43}$ P. Herr \& A. Fleisher, supra note 34, at 26 (Table 10). 
residence to be near his job." 44 The black may lack that mobility. The transportation problem of the urban ghetto dweller may thus be intensified by the fact that it is more difficult for him than for his white co-worker to move near the job site.

Transportation from ghetto to job site is thus needed to offset the effects of residential segregation on work opportunities for blacks. Note, however, that as a conscious policy, this would tend to relieve the pressure for desegregation of suburban residential areas. Viewing the issue as one of transportation policy presumes a choice with regard to a much broader social question-whether policy should be directed toward "breaking up the ghetto" by encouraging workers to move closer to suburban job sites or whether policy should aim toward "gilding" the ghetto by upgrading the socioeconomic status of ghetto residents. ${ }^{45}$ Resolution of this issue is far beyond the scope of this Article. For present purposes we shall assume the adoption of a policy of gilding the ghetto and, more generally, of increasing the mobility of the poor.

The Urban Mass Transportation Administration (UMTA), recognizing that a mass transportation experiment would be justified in Watts, provided a grant to establish a bus line that would take Watts residents to job sites in the Los Angeles International Airport industrial area in about a half hour. ${ }^{46}$ The service was subsidized: Revenues covered only $41.7 \%$ of total costs and $61.5 \%$ of variable costs, the subsidy amounting to fifty-five cents per passenger trip. After two years of operation, the line had an average weekday ridership of $2,841,47$ of whom an average of $58.9 \%$ were on work trips. ${ }^{48}$ As one worker makes two work trips per day, the line carried a daily average of 838 workers. Because only half of the passengers "at most" were Watts residents, ${ }^{49}$ however, it can be assumed that the average number of Watts residents for whom the bus provided transportation to work was no greater than 419 . Some of this number had ap-

${ }_{44}$ Transcript, 2d Sess., supra note 36, at 33 (remarks of Kain); see J. Mayer \& J. Kain, supra note 33, at 3: "In particular, blue-collar or less skilled job opportunities have decentralized more quickly than minority group residential opportunities."

${ }^{45}$ See Transcript-Third Session, Conference on Poverty and Transportation (Am. Academy of Arts \& Sciences), June 7, 1968, at 2 (remarks of Meyer) [hereinafter cited as Transcript, $3 \mathrm{~d}$ Sess.]. Note that dispersion could be only partially successful, leading to a ghetto "brain drain."

${ }^{46}$ See generally T. Floyd, supra note 33 , at 4-5.

${ }^{47}$ Id. 15 (Table 3).

${ }^{48}$ Id. 27 (Table 5). See also Haar, supra note 42, at 524.

${ }^{49} \mathrm{M}$. Wohl, supra note 10 , at 4 . 
parently endured less convenient or more expensive transit modes prior to the establishment of the Century Boulevard line, because an on-bus survey found that only 220 Watts residents obtained jobs because of the service. ${ }^{\mathbf{5 0}}$

The failure of the Century Boulevard bus line to attract more work trips indicates that unemployment in Watts may be traced more directly to causes other than a lack of adequate transportation. ${ }^{51} \mathrm{~A}$ job demonstration program established in Watts by the Department of Housing and Urban Development, in conjunction with the establishment of the Century Boulevard line, resulted in non-referral of $85 \%$ of the 9,383 residenis of Watts who applied for the kinds of jobs available in the Airport area, because they lacked the necessary skills. ${ }^{52}$ Data collected at Watts indicated that some employers were using the transportation barrier as a convenient excuse for not hiring for other reasons. ${ }^{53}$ "Once transportation was provided the job dis-

${ }^{50} \mathrm{~T}$. Floyd, supra note 33, at 28. A similar experience is reported for Nassau and Suffolk counties in New York. See Tri-State Regional Planning Comm'n, People, Transportation, Jobs 8 (1973). Of twenty-two new bus routes started to transport urban unemployed to job sites, six survived. The average subsidy was $\$ 1.03$ per passenger. On the average, fares were $20.4 \%$ of operating expenses.

"Generally, these busing-to-work programs were not successful." Notes, Travel in the Black Ghetto, in Transit FOR THE Poor, supra note 11, at 49. See also Goerig \& Kalachek, Public Transportation and Black Unemployment, SocieTy, July-Aug., 1973, at 39, 42 ("a dismal disappointment"). The Urban Employment Survey (July 1968-June 1970) "does not answer the essential public policy question of whether investment in a transportation system that enhances reverse commutation can increase suburban jobholding by innercity residents ... ." McKay, Commuting Patterns of Inner-City Residents, 96 MONTHLY LABOR Rev., Nov., 1973, at $43,47$.

For a "successful" project, see Baltimore Dep't of Transit \& Traffic, Final RePort, Job Express Transportation (UMTA Project No. MD-MTD-3, 197I). In this case, "success" meant the decision of the Metropolitan Transit Authority (M.T.A.) "to take over all of the existing JET [Job Express Transportation] routes on a permanent basis. These routes had developed to a level where the M.T.A. felt they would be a profitable permanent operation." Id. 2. Some doubts about the true "feelings" of the M.T.A. directors are cast by the facts that the JET staff organized a letter-writing campaign to "urge" the M.T.A. to take over the JET lines and that, at a meeting between JET representatives and the mayor of Baltimore, the mayor was asked "to use his influence to expedite M.T.A.'s 'final' decision." Id. 46-48.

${ }^{51}$ A similar experiment in Boston, in which an employer ran a bus from Roxbury to a suburban plant, was dubbed the "Black Congo Express" and "was not viewed entirely with favor by the community." Transcript, 1st Sess., supra note 35, at 30 (remarks of Doeringer). In the early days of the Century Boulevard line, though, Watts residents considered it "their own" line. This proprietary attitude was evidenced by a low rate of vandalism and the absence of robberies or muggings. See Transcript, lst Sess., supra note 35 , at 8 (remarks of Meyer). The forcefulness of this observation was somewhat undercut by the "rapidly rising crescendo of robberies which eventually reached one per day during November (1967)." Id. (remarks of Floyd).

${ }^{52} \mathrm{See}$ T. Floyd, supra note 33, at 5.

${ }^{53}$ See Transcript, 3d Sess., supra note 45, at 40-41 (remarks of Floyd). See also 
appeared." 54 Finally, the jobs in the suburban-ring factories were generally in the $\$ 4,000-\$ 5,000$ (1968) per year range, and once a ghetto resident became permanently employed at that level he usually acquired an automobile. ${ }^{55}$ Thus the real transportation handicap suffered by the ghetto dweller was the lack of transportation for job hunting. ${ }^{56}$

The deprivation caused by lack of access to an automobile is alleviated most directly by providing access to an automobile. ${ }^{57}$ To argue that mass transportation systems can provide the needed transportation is to ignore the implications of the word "mass." Moreover, it is to ignore an already existing transportation system which presently satisfies all the requisites of a transportation system for the poor and the handicapped save one - cost. That system is the taxi.

Mooney, Housing Segregation, Negro Employment and Metropolitan Decentralization: An Alternative Perspective, 83 Q. J. Econ. 299, 309 (1969) (separation of residence and suburban job locations does not play major role in determination of male nonwhite employment).

54 Transcript, 3d Sess., supra note 45 , at 41 (remarks of Floyd).

${ }^{55}$ See E. Kalacheck, supra note 40, at 8 . In New York, workers frequently switched from buses to carpools soon after starting work, Tri-State Regional Planning Comm'N, supra note 50 , at 4 .

A study undertaken in New Jersey indicated that suburban employers offering an average wage of $\$ 1.85$ per hour had vacancies and the employers cited the lack of adequate public transportation as one of the main reasons why these jobs could not be filled. When employers offered jobs that paid $\$ 2.50-\$ 2.60$ per hour, there was no evidence of transportation difficulties. Transcript, 2d Sess., supra note 36, at 43 (remarks of Hein); see Floyd, supra note 33, at 17. See also Transcript, 2d Sess., supra, at 41 (remarks of Floyd). A study of unemployment and transportation in Nassau and Suffolk counties in New York also produced the observation that the "[p]ressure for new bus services often came from industries having low pay scales and, hence, more jobs available." TRI-STATE Regional Planning Comm'n, supra, at 3. See also Transcript, 3d Sess., supra note 45, at 18 (remarks of Meyer). An alternative possibility is joining a carpool. See Kinley, supra note 6 , at 122.

A "job jitney" experiment was instituted in Watts along with the Century Boulevard bus line. Unlike the usual jitney service, it was intended that "there would be big car pools with the driver driving the bus and working in the plant or at the same complex ...." Transcript, 3d Sess., supra, at 40 (remarks of Floyd). In effect the job jitney program was a formalized carpool. The routes were subsidized with costs averaging $6 x$ per mile and fares running about 2.5-3t per mile. See Floyd, supra, at 18 . The results were disappointing as the lines "attracted almost no patronage." Transcript, 3d Sess., supra, at $40-41$ (remarks of Floyd). The failure is attributed to the factors that led to similar results on the Century Boulevard line.

${ }^{56}$ See, e.g., Transcript, 2d Sess., supra note 36, at 30 (remarks of Kraft). But see Lee \& Covault, Model Cities Transportation Study: Determining the Needs and Desires of Low-Income People in Atlanta, Georgia, 26 TRAFFIC Q. 441, 457 (1972) ("surprisingly few residents have problems with transportation [with regard to 'holding or applying for a job']").

${ }^{57}$ See S. Myers, Personal Transportation for the Poor, Conference on Poverty and Transportation (Am. Academy of Arts \& Sciences), June 7, 1968, at 16. The Regional Plan Association in New York City "proposed such measures as a subsidy for downpayments on small cars, a reduction in auto-insurance costs for low-income people, in- 
Taxicabs are the major form of urban public transportation, traveling almost twice the number of revenue miles as bus and fixed rail systems and garnering about sixty percent of all intraurban transit revenues. ${ }^{58}$ There is some evidence that the poor already are disproportionately large users of taxicabs. ${ }^{59} \mathrm{~A}$ number of plausible explanations have been offered for this

creased parking space in low-income areas and a re-evaluation of policies that have led to a virtual moratorium on new expressway construction in the city" " to increase job opportunities. N.Y. Times, Mar. 19, 1973, at 1, col. 5. The city's Environmental Protection Administration " 'dissociated' itself from the report." Id. 37, col. 7.

The greater number of jobs available to auto passengers than to transit users is a familiar phenomenon. See, e.g., B. Hutchinson, Principles of Urban Transport Systems Planning 5 (1974):

Accessibility to jobs from a low-income area in Nashville

\begin{tabular}{ccc}
\hline $\begin{array}{c}\text { Travel } \\
\text { time (min) }\end{array}$ & $\begin{array}{c}\text { Percent jobs } \\
\text { available by } \\
\text { car }\end{array}$ & $\begin{array}{c}\text { Percent jobs } \\
\text { available by } \\
\text { transit }\end{array}$ \\
\hline $0-10$ & 50.4 & 2.6 \\
$10-20$ & 30.3 & 7.0 \\
$20-30$ & 13.2 & 14.0 \\
$30-40$ & 6.1 & 34.7 \\
$50-60$ & 0 & 6.6 \\
Inaccessible & 0 & 26.4 \\
\hline
\end{tabular}

Road and transit travel times for suburban zone in Toronto, Ontario.

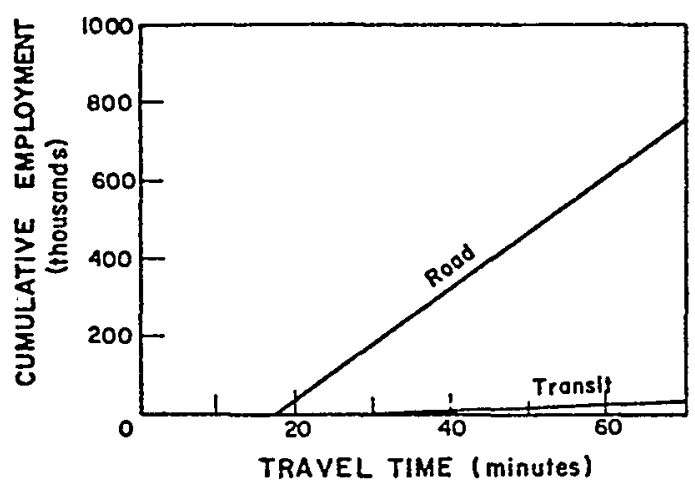

The greater job accessibility is a function of the greater distance that can be traversed by automobile in a given time and the flexibility provided by the automobile's ability to reach points falling between transit routes.

${ }^{38}$ See R. Kirby, Para-Transit: A Summary Assessment of Experience and Potential (1974).

${ }^{59}$ See S. Myers, supra note 57, at 23 (average income of taxi riders in surveys in Columbia, South Carolina, was $\$ 4,800$ per year). See also R. KIrbY, Para-Transit: 
paradox, such as that the poor view more events in their lives as emergencies $^{60}$ or that the transportation expenses of the working poor, particularly domestics, are subsidized by their employers. An intriguing theory of "compensatory consumption" hypothesizes that poor people pick one or two items like a television set or taxicab or something else with which they will indulge themselves as a way of compensating for other things they want but cannot have. ${ }^{61}$ It may be that higher taxicab use is simply a function of the absolute lack of alternative transportation modes.

The manifest difficulty with the present taxi system is its cost to the user. A not insignificant component of this cost results from the absolute limitation by law of the number of taxicabs in most major urban areas. ${ }^{62}$ The demand for taxi service is such that taxi operators are able to obtain monopoly rent which is reflected in the high cost of taxi "medallions," ranging from $\$ 7,500$ per medallion in Detroit to $\$ 30,000$ in Boston. The medallion system also makes taxi owners monopsonists in employing drivers, and they exercise this power to keep wages at a level of $\$ 100$ to $\$ 125$ for a fifty-to-sixty-hour week. ${ }^{63}$ The effect of permitting free entry into the taxicab market can be estimated by the experience in Washington, D.C. In Washington there are 13.3 taxicabs per thousand population, most drivers are selfemployed, their taxis are family cars, ${ }^{64}$ and over $75 \%$ work parttime. If the Washington experience were duplicated in currently

Neglected Options for URban Mobility 166 (1974); Transcript, 1st Sess., supra note 35, at 18 (remarks of Schneider). But see Lee, Falcocchio, \& Cantilli, Taxicab Usage in New York City Poverty Areas, in Transit for the Poor, supra note 11, at 1.

${ }^{60}$ See Transcript, Ist Sess., supra note 35, at 22 (remarks of Fellman).

61 Id. 21.

62 "[O]bsolete franchise limitations and market-entry barriers for taxicabs and jitneys, restricts the efficient operation of the urban transportation system." U.S. DEP'T OF Transportation, 1972 National Transportation RePORT xvi, cited in Roth, Regulation of Buses in Cities, in Price-Subsidy Issues in Urban Transportation 21 (Highway Research Record No. 476, 1973) [hereinafter cited as PRICE-Subsidy Issues].

The New York City Traffic and Limousine Commission has limited the number in that city to 11,787 by not reissuing the nearly 1,800 medallions surrendured since 1937 . See R. KIRBY, supra note 59 , at 89 n.9. There were 1.5 taxis per 1,000 population in New York, 1.4 in Chicago, 0.9 in Detroit, and 2.5 in Boston in 1970. Id. 104 (Table 7.3). In the absence of these limitations, the "taxi industry would approximate the characteristics of perfect competition." Beesley, Regulation of Taxis, 83 EcON. J. 150, 151 n.2 (1973).

${ }^{63} \mathrm{~S}$. Rosenbloom, Taxis, Jitneys and Poverty, Conference on Poverty and Transportation (Am. Academy of Arts \& Sciences), June 7, 1968, at 18. See also R. KIRBY, supra note 59, at 123 (1970 study of twenty-seven fleets indicates median wage of $\$ 1.85$ per hour plus tips and fringe benefits).

64 "It has always been recognized that one advantage of the London 'free entry' conditions is that drivers entering the trade could realistically look forward to becoming proprietors themselves." Beesley, supra note 62, at 170. 
regulated cities, there would be an estimated $250 \%$ increase in drivers' jobs ${ }^{65}$ and a huge increase in ghetto mobility, because the costs of owning a private vehicle would be offset by devoting it to part-time taxi service.

Deregulation would also bring the social benefit of decreasing racial discrimination in the provision of taxi service: In the present oligopoly market with unsatisfied demand, drivers can afford to discriminate, but such discrimination would be economically inefficient in a deregulated market. ${ }^{66}$ A deregulated taxi system would not only go far to alleviate the transportation problems of the poor but would also provide more economical and frequent service for all taxi users. The major cost involved would be compensation for present medallion owners. Even if they were compensated at prevailing market prices, however, the costs would appear insignificant beside those of transit programs currently being planned in major urban areas. ${ }^{67}$ In the event that the removal of barriers to entry did not lower taxi fares to a level considered "socially desirable" for the poor and the handicapped, coupons could be provided to members of these groups for use in payment of taxi fares. ${ }^{68}$ It has been estimated that 1.2 million handicapped could be served by taxis at a cost of $\$ 250$ per person per year or a total cost of $\$ 300$ million. ${ }^{69}$ This cost could be reduced if only part of the fare were subsidized. It has been estimated that this service would enable 200,000 of the chronically handicapped to enter the work force, ${ }^{70}$ thereby adding $\$ 800$ million to the Gross National Product. ${ }^{71}$

${ }^{65}$ See D. Gurin \& J. Wofford, Implications of Dial-A-Ride for the Poor, Mar., 1971, at 3-2 (employing the poor as drivers, mechanics, and so on, "in the long run might be the most significant contribution Dial-a-Ride could make to combatting poverty").

${ }^{66}$ See S. Rosenbloom, supra note 63, at 26.

${ }^{67}$ For New York City, for example, the cost has been estimated to range from $\$ 140$ to $\$ 250$ million. Amortized over 10 years at $6 \%$, the annual tax burden would be $\$ 19$ to $\$ 34$ million. R. KIRBY, supra note 59 , at 404 .

${ }^{68}$ See, e.g., N.Y. Times, June 14, 1974, at 1, col. 4; Roth, supra note 62 , at 25 . Other lessons to be learned from the Washington experience include the economic advantages of a zone fare system over one based on mileage. Costs of taxi service could also be lowered by allowing group riding and picking up passengers at more than one location.

69 See Manual, supra note 6, at 19. But see Schnell, Public Transportation and Transportation Needs of the Elderly and Handicapped, in TRANSPORTation FOR THE POOR, supra note 8, at 1, 6: "Not all cab drivers are young enough and strong enough to help a handicapped person from the wheelchair and into the cab. Not all are good-natured enough. Not all are willing to accept the responsibility."

${ }^{70}$ See Travel Barriers, supra note 27, at 19.

${ }^{71}$ Id.

It is interesting to note that "transit dependents" were the principal users of the San 


\section{Summary}

An attempt has been made to determine the extent to which the urban transportation problem involves the "transportation disadvantaged." Of the four groups comprising this category, those under twenty seem not to be disadvantaged even within the narrow definition of automobile availability. The elderly do not form a relevant group for present purposes except to the extent that they are either poor or handicapped. Of these latter two groups, there is no evidence indicating that the handicapped desire to travel during limited hours or to restricted destinations; and the data indicate that the handicapped are scattered throughout the general population in low densities ranging from 98 to 200 persons per square mile. ${ }^{72}$ The only group that might present a case for mass transportation is the poor, because, as the term implies, mass transportation is designed to move numbers of people. The quantity of passengers needed to keep fares low can only be generated by a concentration of demand on a geographic and temporal basis. Considering that the journey to work is the mass transportation trip and that the problem of the poor seems to be the lack of transportation facilities for the journey to work, that problem is the only one that mass transportation might be able to solve. ${ }^{73}$

\section{B. Congestion}

In its statement of findings and purposes, Congress identified intensification of traffic congestion as a principal part of the urban transportation problem. ${ }^{74}$ What is this "congestion"? A lay response might be "too many cars." For the traffic planner congestion is the average delay imposed by vehicles on each other. ${ }^{75}$ The measure of congestion is therefore the difference

Jose "dial-a-ride" experiment. That system failed because of an excess of demand for trips at $25 t$ each. This resulted in long delays in service, and a labor dispute resulted in an increase in costs so as to require estimated subsidies of as much as $\$ 4$ per passenger per trip. See N.Y. Times, May 13, 1975, at 15, col. 1.

72 UMTA, supra note 12, at 5 (Figure 3.1).

${ }^{73}$ But see Kinley, supra note 6, at 121 (another reason for the failure of these programs was the erroneous premise that "the disadvantaged were concentrated in small, residential 'pockets' ").

${ }^{74}$ See C. Villarreal, supra note 6, at 50, 54-55; Hedges, Let's Áttack The Real Urban Transportation Problem, in Public Transportation Planning Issues 10-11 (Transp. Research Record No. 519, 1974). Congestion is not a new problem. The ancient Romans attempted to deal with it by prohibiting wheeled vehicles from using the streets during the daytime. See J. Rae, The Road and the Car in American Life 10 (1971).

${ }^{75}$ See generally Meyer, supra note 4, at 48-50. 
between the speed at which a vehicle could move without delay caused by other traffic and the actual average traffic speed. ${ }^{76}$ The planner uses the concept of "excessive congestion" to describe what most of us would consider simple congestion. "Excessive congestion" is the difference between the economic speed -that is, the point at which further increments in traffic are not worth the delays to the existing traffic stream-and the actual average speed. ${ }^{77}$ While this definition is more satisfying, and lies at the heart of the analysis usually relied upon to justify expansions of highway capacity, it appears not to be the one used by Congress to support the mass transit program.

Congress seems instead to have had in mind a conception of congestion that is best described as a "failure of anticipations." In short, "the trip is taking too long." Objectively, for the work trip at least, this is not the case. The time from home to work and vice-versa has been reduced over the past twenty years from an average of twenty-five minutes to an average of twenty minutes. ${ }^{79}$ Moreover, street patterns in the central business districts rarely were planned to accommodate motor vehicle traffic. ${ }^{80}$ The "failure of anticipations" cannot therefore be at-

${ }^{76} \mathrm{~J}$. Thomson, Methods of Traffic Limitation in Urban Areas 29 (1972). The amount of congestion is the difference between free speed (at which a vehicle can move without delays due to traffic) and actual (average traffic) speed.

${ }^{77}$ Id. 30.

${ }^{78}$ Meyer, supra note 4, at 49-50.

79 "For people who lived 3 miles from the heart of the city in 1890 , from 30 to 45 minutes was required to get downtown by a streetcar." Bostick, The Automobile in American Daily Life, 32 Pub. Roads 241 (1963).

${ }^{80}$ See generally J. RAE, supra note 74, at $299-300$. Jane Jacobs notes that city streets were not adequate even for horse traffic. See J. Jacobs, The DeAth ANd LifE of GrEat American Cities 341 (1961).

It is obvious that few streets in CBD's were laid out with motor vehicles in mind; it may be of passing interest to know what the planners did have in mind. In Cincinnati, for example, most street rights of way were laid out in the nineteenth century at sixty-six feet wide, with forty-foot roadways and thirteen-foot sidewalks. The reason for the sixty-foot width was that this was the length of a Gunter's chain, utilized by surveyors to subdivide acreage. See Bird, How to Plan for the Pedestrian, 84 AM. CIry, July, 1969, at 76, 77. The rectangular grid pattern of Philadelphia's streets was designed to facilitate the establishment of orderly property lines. J. RAE, supra note 74, at 198.

Washington's broad avenues were intended "partly for beautification, partly for prestige and quite largely to facilitate the suppression of revolts." Id. The same is true in Europe, where the streets of Essen, for example, were laid out in the ninth century. Office of Int'l Affairs, U.S. Dep'T of Housing and Urban Development, HUD INTERNATIONAL BRIEF No. 16, at 14 (1972) [hereinafter cited as HUD BRIEF]. Rouen's downtown streets follow the moats which encompassed the city's walls in the sixteenth century. The street pattern of the Norwich central city was established by the eleventh century. Even Manhattan's streets, which were laid out in the early nineteenth century with some consideration given to traffic, were designed on the assumption that most 
tributable to expectations about movement on the street network of most central business districts.

The most plausible explanation attributes the failure to the widening gap between speeds attainable on limited-access highways during off-peak hours and those attainable on urban portions of such highways during peak commuting hours. If this perception lies at the root of the "congestion problem," there seems to be little that can be done about it. A massive education program to make people realize that they cannot expect to drive as quickly during the rush hour as during the off-peak hours would be a non-starter. Moreover, planners have learned to their dismay that a Parkinson's law of traffic operates to fill every newly constructed road without significantly relieving traffic volume on the previously existing routes. ${ }^{81}$ The only way to eliminate the traffic planners' "excessive congestion" and the frustrated commuter's perception of congestion is to limit the number of vehicles on the road. But it is congestion that discourages the additional driver from using his car and that places the ultimate limit on vehicular traffic. The planner or policy maker who wants to decrease vehicular traffic thus should recognize that congestion will occur at any feasible level of highway construction. $^{82}$

\section{The Automobile Commuter}

In its administrative interpretation of the Urban Mass Transportation Act of 1964, the Department of Transportation notes that the program "recognizes that use of the private automobile for the peak-hour work trip is often contradictory of such other community objectives as pure air, quiet and privacy, socially-desirable land use, efficient concentration of economic activity without undue congestion and enhanced quality of the urban environment"; the goal of the program therefore is "to reinvigorate public transportation in order to provide service

traffic would go by water. See generally E. Parker \& K. Kamrass, Center City Transportation Needs of Transit-Oriented Cities (Summary of the National Urban Coalition Seminar), Apr. 1-2, 1970, at 8.

${ }^{81}$ At one time it was predicted that the automobile would relieve urban street congestion, by moving more people faster than they could travel on foot. See R. CARo, THE Power Broker 910-13 (1974); Mohr, Some Fallacies in Urban Goods Movement, in UrbaN Goods Movement 105, 107 (Transp. Research Record No. 496, 1974) [hereinafter cited as URBan Goods Movement]; Rae, The Mythology of Urban Transportation, 26 Traffic Q. 85, 92 (1972).

${ }^{82}$ See generally text accompanying notes $260-63$ infra. 
that will attract new riders" and, in particular, "to attract the auto commuter on his journey to and from work." 83

The journey to and from work by the automobile commuter lies at the heart of the urban transportation problem for three reasons. ${ }^{84}$ First, work trips are the largest single category of home-based auto trips. ${ }^{85}$ Second, work trips are crammed within a limited time. ${ }^{86}$ Third, work trips follow a radial pattern: toward the central business district in the morning and out from the center in the evening. ${ }^{87}$ Because work trips occur in large volume, during a limited time, in the same general direction, along narrow traffic corridors, they are the trips for which mass transportation can be employed to best advantage in competition with the automobile. An examination of the program incorporated in the Urban Mass Transportation Act of 1964 indicates

${ }^{83}$ Manual, supra note 6, at IIB-16 (1972). See McManus, Financing Public Transportation, in Issues in Public Transportation 30, 34 (Transp. Research Bd. Special Rep. No. 144, 1974); J. Volpe, Transportation and Human Needs in the 1970's, Conference, Conference on Transportation and Human Needs in the 70's (Am. U.), June 20, 1972, at 184,185 ("Our most compelling task is to revitalize urban transportation-to release the stranglehold the automobile has on our cities.").

${ }^{84}$ See Kain \& Beesley, Forecasting Car Ownership and Use, 2 Urban Studies 163, 171 (1965): " $[\mathrm{T}]$ he work-trip . . . made during peak hours . . . is the principal component of the peaking .... [ which is in turn] the principal problem with which urban transportation policy has to deal ...." See also Great Britain Ministry of Transport, SteEring Group Report, Traffic in Towns 25 (1963) [hereinafter cited as Traffic in Towns] ("The car-commuter, the worker who uses his car to travel between home and work, is the heart of the urban traffic problem ...."); L. Firch, Urban Transportation and Public Policy 9 (1964).

${ }^{85} \mathrm{~A}$ twelve-city study indicated that $34 \%$ of all home-based trips are journey-to-work trips. (The next largest category was "social-recreational" at $21 \%$.) A more recent Atlanta study indicated that $27 \%$ of all weekday trips were trips between home and work. See $\mathrm{L}$. Fiтch, supra note 84, at 33; Tarpley \& Dake, The Timing of Urban Transport Decision, in New Perspectives in Urban Transportation Research 246 (A. Catanese ed. 1972); Motor Vehicle Manufacturers Association, 1973-74 Automobile Facts and Figures 37 (32.2\% of all passenger car trips are to and from work). During the peak, the number of work-related trips is much higher. A survey in Washington, D.C., showed work trips to be the purpose of $62 \%$ of auto drivers, $78 \%$ of auto passengers, and $67 \%$ of transit riders. L. FITCH, supra, at 33.1963 Boston figures indicate that $66 \%$ of all auto trips during the morning peak and $40 \%$ in the evening peak are work trips. See G. Kraft \& T. Domencich, Free Transit, Conference on Poverty and Transportation (Am. Academy of Arts \& Sciences), June 7, 1968, at 27. In Amsterdam and Rotterdam, in the Netherlands, the journey to work is the largest share of peak hour capacity. See F. DE Donnea, The Determinants of Transport Mode Choice in Dutch Gities 202 (1971).

On the other hand, "most urban travel demand is other than downtown-oriented. In many large cities, less than 10 per cent of total person trips begin or end in the CBD." Washington ranks highest with 35\%; Pittsburgh lowest, with only 7\%. S. Myers, supra note 57 , at 3 .

${ }^{86}$ See Tarpley \& Dake, supra note 85, at 246.

${ }^{87}$ Journeys to work are also the most "rational" of all auto trips from the point of view of consideration of alternatives, see id.; and the automobile occupancy rate is lower for work trips than for trips of other kinds, see Bostick, supra note 79, at 243. 
that Congress also perceived the automobile journey to work as the urban transportation problem. Before examining the Act, however, it would be well to look more closely at the "community objectives" with which use of the automobile conflicts.

\section{iII. System Costs of Automobile Commuting ${ }^{88}$}

\section{A. The Automobile as an Energy Waster}

Fifty percent of United States crude oil consumption is in the form of fuels for motor vehicles, ${ }^{89}$ with automobiles accounting for $71 \%$ of this total. ${ }^{90}$ Automobiles consumed $16.1 \%$ of the nation's total Net Energy Input in 1969.91 In 1972 the average automobile in the United States consumed 735 gallons of gasoline. ${ }^{92}$ While these figures show the automobile to be a large consumer of petroleum products, they tell us nothing about "inefficient" use or "waste" of resources.

Relative figures are needed to make such judgments. Automobiles are used for $29 \%$ of all commercial passenger transportation, but they consume $65.5 \%$ of all the fuel used for that purpose. Their "normalized efficiency," the quotient of these two figures, is thus .44. Buses and trains, with a normalized efficiency of 1.33, are approximately three times as efficient as automobiles. ${ }^{93}$ Another statistic indicating the relative inefficiency of private autos as compared to mass transit is the "net propulsion efficiency" (NPE), or average passenger-miles per gallon of gasoline (or 130,000 BTU equivalent). The most efficient vehicle, based on this widely used measurement, is a Volkswagen microbus carrying seven passengers (NPE approximately 350 ). A rush hour rail rapid transit system has an NPE of 120, as does a small car with four passengers. Less efficient are the evening rush hour bus (NPE 92), the noon rapid transit (NPE 60), the small car with two passengers (NPE 60), the noon city bus (NPE 40), and the ordinary sized car with two passengers (NPE 36). As might be expected, the large car with

${ }^{88}$ Motorist-imposed costs on "highway authorities, other road users or society at large" are termed "system costs." J. THOMSON supra note 76, at 3.

${ }^{89}$ G. Leach, The Motor Car and Natural Resources I (1973).

${ }^{90}$ Id. 15.

${ }^{91}$ Id. If one includes the energy consumed in producing vehicles, roads, and so on, the figure rises to about $40 \%$. Id. 13 .

92 Motor Vehicle Manufacturers Association, 1972 Automobile facts and Figures 52.

${ }^{93}$ G. LEACH, supra note 89 , at 35 (Figure 6). 
one passenger is the least efficient vehicle (NPE 8). Considering that the average occupancy rate of automobiles used in work trips is 1.3 , clear savings in energy could be made by shifting commuters to mass transportation. ${ }^{94}$

Moving automobile commuters to mass transit is not, however, the only way to decrease automobile energy consumption. The average consumption of gasoline per automobile in Europe is only half the rate in the United States. ${ }^{95}$ Because average mileage traveled is approximately the same, the difference must be attributable primarily to engine size and auto weight. Thus if a trend toward compact cars were to develop, American oil consumption for auto fuel could be cut in half and total American oil consumption cut by seventeen percent. ${ }^{96}$ Consumer preferences aside, however, a cost exists in moving to smaller cars. Statistics indicate that they offer less protection in the event of accidents than do full-sized models. Extrapolations from existing data indicate that a move toward smaller cars would be paralleled by an increase in personal injuries and fatalities resulting from automobile accidents. ${ }^{97}$ But because the fuel savings associated with smaller sedans are a function not of size but of weight, even if Americans refused to give up large cars, significant energy savings could be obtained by substituting aluminum and magnesium for steel and copper in present-day automobiles. ${ }^{98}$

The author is aware of no cost-benefit analysis comparing the relative feasibility of energy conservation by reducing automobile weight instead of automobile use. The explanation for the paucity of literature undoubtedly lies in the facts that no extant mass transportation system is attractive enough to lure the

${ }^{94}$ Id. 32 (Figure 5). See generally Orski, The Potential for Fuel Conservation: The Case of the Automobile, 8 Transp. Research 247, 251 (1974): "Greater use of mass transit undoubtedly forms the single most important element of any long-range strategy for conserving energy in transportation." A more immediate and less capital-intensive means of energy conservation would, of course, be to raise the occupancy rate on auto trips. Such an effort would involve "carpooling." For the spectacular effects of increased occupancy on energy consumption and pollution, see, e.g., Pratsch, Carpools: The Underutilized Resource, 44 Civil ENG'R, Jan., 1974, at 49.

95 G. LEACH, supra note 89, at 15. See Harris \& Hille, Rail, Truck or Small Car-Which is the Energy Saver?, 17 Bus. Horizons 57, 63-64 (1974).

${ }^{96} \mathrm{G}$. LEACH, supra note 89 , at 31 .

${ }^{97}$ Boston Globe, Jan. 13, 1974, at A-83, col. 2.

${ }^{98}$ Aluminum in particular is being used increasingly for trim, radiator grilles, body panels, gearbox casings, cylinder heads, and engine blocks, as well as entire engines. See G. LEACH, supra note 89 , at 47 . It is estimated that new federal safety and pollution standards will increase the weight of a "normal car" by $17 \%$. Id. 
commuter from his automobile and that we do not know the cost of constructing such a system. The very purpose of the Act is to provide this knowledge. What we do know is that a significant decrease in petroleum consumption would result if the commuter could be induced to leave his automobile and take the bus, streetcar, or subway.

\section{B. The Automobile as a Polluter}

The House Report accompanying the Act noted that the "fumes from motor vehicles are contributing to smog problems which have become so acute in some areas as to present a real danger to the health of urban dwellers." ${ }^{99}$ Of the approximately 208 million tons of contaminants added to the airspace of the United States each year, roughly 105 million tons come from transportation vehicles, an average of almost one ton per year for each car, truck, or bus in the United States. ${ }^{100}$ The principal contaminants emitted by motor vehicles are nitrogen oxides, hydrocarbons, and carbon monoxide. ${ }^{101}$ In addition to physical

99 House Comm. on Banking and Currency, Urban Mass Transportation ACt of 1963, H.R. REP. No. 204, 88th Cong., lst Sess. 5 (1963) [hereinafter cited as H.R. REP. No. 204].

100 Motor Vehicle Manufacturers Association, 1973-74 Automobile Facts AND Figures 15-16. But see letter from Robert S. Krotschmar, Division Manager, Automobile Association of America, to John A.S. McGlennan, Administrator, Environmental Protection Agency, quoted in part in AAA Newsletter, Massachusetts Division, Fall, 1973, at 12: "[W]hen the weight of air pollutants emitted by all sources in the United States was adjusted on the basis of toxicity, motor vehicles as a source of pollutants dropped from a rating of 60 percent based on weight to a rating of 12 percent based on toxicity."

${ }^{101}$ Motor vehicles emit $64.7 \%$ of all carbon monoxide, $45.7 \%$ of all hydrocarbons, and $36.6 \%$ of nitrogen oxides. Environmental Protection Agency, Development of Systems to Atrain Established Motor Vehicle and Engine Emission Standards 4-1 (1971), reprinted in Environmental Directorate, Organization for Economic Cooperation and Development, Environmental Implications of Options in Urban Mobility II-5 (1973) [hereinafter cited as Environmental Directorate]. See Pennsylvania v. EPA, 500 F.2d 246, 248 (3d Cir. 1974).

For urban areas these figures are substantially higher. For the following OECD Metropolitan Areas, the percentages of carbon monoxide emissions from motor vehicles were as follows: New York City 97, Chicago 94, Los Angeles 98, Philadelphia 70, Washington, D.C. 96, Pittsburgh 80, Madrid 95, Stockholm 99, Tokyo 99, Toronto 98. With regard to hydrocarbons the figures are: New York City 63, Chicago 81, Los Angeles 66, Philadelphia 47, Washington, D.C. 86, Pittsburgh 70, Madrid 90, Stockholm 93, Tokyo 95, Toronto 98 . And in the case of nitrogen oxides, which are usually produced in slightly greater numbers by stationary fuel ignition than by motor vehicles, this was not the case in Los Angeles (72\%), Washington (44\%), and Stockholm (53\%). ENvironMental Directorate, supra, at II-6.

Of the three, carbon monoxide emissions are the most dangerous because they can lead to death by asphyxiation by combining with the hemoglobin in the blood more readily than does oxygen. (The traditional theory has been challenged by research indicating that "carbon monoxide poisons by disrupting the 'cytochrome system' of the body's 
injury it is estimated that air pollution generated by motor vehicles causes $\$ 6.6$ billion in property damage annually. If a significant number of automobile commuters were diverted to mass transit, CBD air pollution could be reduced. Vehicles used in mass transit also pollute but on a proportionally lower basis. ${ }^{102}$

The danger posed by automobile emissions has been recognized by Congress in the Air Quality Act. ${ }^{103}$ The approach taken in the Act is to persuade the automobile manufacturers to rede-

tissue cells," that oxygen displacement is not the cause of death, and therefore that carbon monoxide levels in the blood may not be sufficient indicators of the degree of poisoning. See Boston Globe, Oct. 23, 1974, at 22, col. 1-2.) Exposure to levels of $30 \mathrm{ppm}$ (parts per million) for 8-12 hours can impair psychomotor performance and increase physiological stress in patients with heart disease. Environmental Directorate, supra, at II-2.

There is some dispute about acceptable levels of carbon monoxide. The standard set by the Environmental Protection Agency (EPA) is 9 ppm, average maximum eight-hour concentration. This is regarded as unduly stringent in Europe. See RoAd RESEARCH Group, Organization for Economic Cooperation and Development, Effects of Traffic and Roads on the ENVIRONMENT in URban AReas 29 (1973) [hereinafter cited as OECD Road Research Group]. In France, for example, a range of 15-40 ppm has been proposed with the upper limit to be exceeded not more than $1 \%$ of the time per year and the lower range to be surpassed at least $15 \%$ of each eight-hour period. Id. 30 .

New York State guidelines recommend that a level of $1.5 \mathrm{ppm}$ not be exceeded more than $15 \%$ of the time every eight hours. Measurements in midtown Manhattan indicate that this level is consistently exceeded, with emissions reaching levels of $25-30 \mathrm{ppm}$ during rush hours and $100 \mathrm{ppm}$ in the Lincoln Tunnel and at the approach to the George Washington Bridge. See R. Buel, Dead End 64 (1972).

The standards of the Clean Air Act of 1971 are designed to keep blood carboxyhemoglobin (COHb) levels below the $1.5 \%$ saturation level. In a thirty-month study of 29,000 blood donors across the United States, "[f]orty-five percent of the nonsmoking blood donors had COHb saturations in excess of 1.5\%." Stewart et al., Carboxyhemoglobin Levels in American Blood Donors, 229 J.A.M.A. 1187, 1193 (1974).

Nitrogen oxides and nitrogen dioxide in particular are associated with acute bronchitis in infants and school children and serious respiratory disease in adults. Incidence of respiratory disease is increased when nitrogen dioxide levels average $.06 \mathrm{ppm}$ to .08 ppm over six-month periods. See Environmental Directorate, supra, at II-3. The average level on "busy streets" is .2 ppm, see OECD RoAd Research Group, supra. The EPA standard is $.05 \mathrm{ppm}$ annual arithmetic mean, 40 C.F.R. $\S 50.11$ (1974).

Hydrocarbons under conditions of bright sunlight and still air produce smog, which causes eye irritations and is injurious to plants. The EPA standard is .24 ppm, maximum three-hour concentration. Id. $\$ 50.10$.

${ }^{102}$ A 1970 study indicated that the average rapid transit system uses $5.5 \mathrm{KWH}$ of energy per car mile. See Economic Characteristics, supra note 9, at 2-9, 9-6. If the power used was oil containing $.5 \%$ sulfur, each 1000 car-miles caused the emission of $.015 \mathrm{lbs}$. of carbon monoxide, 1.2 lbs. of hydrocarbons, $41 \mathrm{lbs}$. of nitrogen oxides, and $15.4 \mathrm{lbs}$. of sulfur oxides. For the equivalent distance for one automobile complying with 1974 federal auto emission standards, the figures are 52 lbs. of carbon monoxide, 6 lbs. of hydrocarbons, and 4.4 lbs. of nitrogen oxides (computed from data in Hearings Before the Subcomm. on Air and Water Pollution of the Senate Comm. on Public Works, 93d Cong., 1st Sess., ser. 19 (1973)).

10342 U.S.C.A. § 1857 (Supp. 1975). In particular, § 202 of the Act, 42 U.S.C.A. § $1857 \mathrm{f}-1$, requires that carbon monoxide and hydrocarbon emissions on 1977 automobiles not exceed $10 \%$ of the 1970 level. 
sign automotive power plants so that emissions will not exceed certain prescribed levels. In the early stages of the program quite significant decreases in automobile emissions were achieved. The current effort to achieve the final incremental declines in harmful emissions, however, has proved technologically difficult. Now incremental reductions in harmful emissions may prove so expensive that limiting such emissions by limiting automobile use may be economically more efficient. Moreover, even if designs could be altered to achieve prescribed minimum standards, it may be difficult to insure that automobile owners will keep the emission control systems in their cars working properly.

Although difficulties can be overcome with regard to the expense and operation of periodic testing equipment, individual automobile owners may subordinate interest in clean air to their interest in better performance and fuel economy, both of which are sacrificed by current emission control technology. The case for diverting automobile commuters to mass transit for the sake of cleaner air therefore becomes especially persuasive. ${ }^{104}$

The price of cleaner air may, however, be a loss of hearing. Prolonged exposure to sound at a level of 100 decibels will cause permanent loss of hearing. The New York City subway system average in-car sound level is 95-100 decibels with a peak of $114 .{ }^{105}$ Even a twenty-minute ride on such a system may produce a temporary loss of hearing lasting up to forty minutes after departure from the system. ${ }^{106}$ Sound levels on the platforms range from 93 to 101 decibels. In addition to damage to hearing,

104 "The Committee recognizes that during the next several years, the attainment of required ambient air quality in many of the metropolitan regions of this country will be impossible if the control of pollution from moving sources depends solely on emission controls." Senate Comm. on Public Works, National Air Quality Standards Act of 1970, S. REP. No. 1196, 91st Cong., 2d Sess. 13 (1970). On the other hand, although the number of automobiles in the Los Angeles area increased by about $20 \%$ between 1966 and 1974, total carbon monoxide emissions have been reduced by $50 \%$ and hydrocarbon emissions by more than $60 \%$. N.Y. Times, Feb. $2,1975, \S 12$, at 15, col. 1. In Manhattan trucks are responsible for $50-65 \%$ of vehicle-produced pollutants. Arrow, Coyle \& Ketcham, Environmental Impact of Goods Movement Activity in New York City, in URBaN Goods Movement, supra note 81 , at 80,83 .

${ }^{105}$ N.Y. Times, Oct. 16, 1973, at 74, col. 1. See also Natural Resources Defense Council, New York Can Quiet Its Noisy Subways 6 (1974). The average level of street noise is 75 decibels. The difference, however, is substantial because decibels are measured on a logarithmic scale and a decrease of 10 decibels means a $50 \%$ decrease in the noise level. All references to "decibels" are to " $\mathrm{db}(\mathrm{A})$," that is, decibels as measured on the " $A$ " frequency scale of a sound pressure meter, the frequency closest to that of the human ear.

${ }^{106}$ N.Y. Times, Oct. 16, 1973, at 86, col. 1 (and "anyone who used the subways for 25 to 30 years suffered permanent impairment of hearing"). 
this quantity of sound increases the risk of heart attack and disrupts concentration, thereby increasing the risk of accidents. ${ }^{107}$ The solution to this rail transit problem is not necessarily the replacement of steel with rubber wheels; the two quietest subway systems in the world, in Hamburg and Berlin, have steel wheels. The answer seems to be better maintenance, ${ }^{108}$ but maintenance is so expensive that the New York City Transit system was exempted from application of the City's 1972 Noise Code because compliance might have necessitated a fare increase. ${ }^{109}$

Noise is unwanted sound that is below the level of sound that causes physical impairment. Because the concept of noise involves a subjective element, it is not possible to argue conclusively about noise levels. ${ }^{110}$ Nonetheless, it appears that noise is one of the most annoying features of existing mass transit systems. ${ }^{111}$ The principal cost of substituting buses for automobiles as the primary vehicle for the journey to work would be an increase in noise levels resulting from the increased use of diesel engines. ${ }^{112}$

\section{The Automobile as a Tortfeasor}

The House Report accompanying the Act noted that "[p]ublic safety is another factor to be considered when reviewing problems of traffic congestion. ... Property damage caused by motor vehicle accidents has reached such proportions that insurance companies are continually forced to increase rates in order to have adequate reserves to cover the cost of the damage." 113 The relevant figures for comparison of degree of

${ }^{107}$ Natural Resources Defense Council, supra note 105, at 13-20.

${ }^{108}$ Id. 30, 38. See also J. Urban Transport. Corp., Passenger Psychological Dynamics 116 (UMTA Grant No. H-804, 1968) [hereinafter cited as Passenger PsychoLOGICAL DyNamics] (detailed statistics on subway noise levels).

${ }^{109}$ N.Y. Times, Oct. 11, 1973, at 90, col. 2.

110 Moreover, there is some question about the decibel as an adequate measure of sound. The decibel expresses a relationship between total sound pressure level and a reference pressure. It does not, however, take "account of the ear's decreasing response at low and high frequencies." OECD ROAD RESEARCH GROuP, supra note 101, at 13. In any event, some scientists have speculated that constant exposure to noise may accelerate the process of age-induced deafness (presbycosis). See Environmental Directorate, supra note 101, at II-14. Moreover, traffic noise can interfere with sleep, distract concentration, interrupt conversation, and generally affect the quality of urban life. The Federal Highway Administration has published regulations setting noise standards for all federally-aided highways. See 23 C.F.R. § 772.1-.7 (1975).

111 See L. FIrCH, supra note 84, at 194.

112 See OECD RoAD RESEARCh Group, supra note 101, at 26-27.

${ }^{113}$ H.R. REP. No. 204, supra note 99, at 5. 
safety are accident rates of alternative urban transit modes. Such information is rather sketchy, although in 1971 the American Transit Association reported a passenger death rate of .05 per $100,000,000$ passenger-miles for urban street car, trolly bus, and bus lines. ${ }^{14}$ This compares most favorably with the 1971 urban motor vehicle death rate of 2.9 per $100,000,000$ passenger-miles.

Data on nonfatal accidents is even harder to obtain. A 1968 study of major metropolitan bus lines indicated an accident rate of 5.47 per million passenger trips. The same study gathered data from the subway systems in New York, Boston, and Philadelphia and revealed an accident rate of 7.40 per million passenger trips. There are no comparable automobile figures in existence. The 1968 study also provides accident rates per million vehicle miles. The rate for subways was 32.5 , the rate for buses 77.68.115 The National Safety Council indicates that in 1971-73 the comparable rate for passenger cars was 8.32. This figure, however, is based on the experience of fleet operators of cars used for business purposes. ${ }^{116}$ In the absence of more refined figures, it is impossible to draw conclusions; but it is not irrational to surmise that losses of life, limb, and property could be reduced if commuters were diverted from the automobile to the bus or subway.

\section{The Automobile as a Space Waster}

More than half of the land area in the central business districts of Chicago, Boston, Detroit, and Los Angeles is devoted to motor vehicle movement and storage. ${ }^{117}$ In Providence, $47 \%$ of the CBD's 350-acre land area is devoted to similar uses, while only 16 of those 350 acres are devoted to "publicly usable urban greenspace." 118 Such statistics, however, tell us very little. Streets existed in cities long before the automobile was invented and the need for some form of streets would continue were the automobile to disappear.

One means of restoring perspective to a discussion of the amount of urban land devoted to the automobile is to break

114 National Safety Council, 1974 accident Facts, at 75. Cf. Economic Characteristics, supra note 9, at 9-14 (passenger death rate of .001 per million passenger-miles).

115 ECONOMIC ChaRacteristics, supra note 9, at 9-17.

116 National Safety Council, supra note 114, at 64.

${ }^{117}$ Hearings on S. 6 \& S. 917 Before the Subcomm. on Housing of the Senate Comm. on Banking and Currency, 88th Cong., 1st Sess. 69 (1963) [hereinafter cited as Hearings].

118 See Rhode Island School of Design, Interface: Providence 32, 33 (1974). 
down gross figures into those land areas devoted to streets and those devoted to off-street parking. The latter type of land use is particularly associated with the use of private automobiles for urban transportation. Thus, although $49.5 \%$ of the land of Detroit's central business district was devoted to streets and parking in 1953, the parking share was only $11 \%$. The core area of Dallas' CBD had $52.6 \%$ of its land devoted to streets and parking; the latter category was $18.1 \%$. The extreme case is Los Angeles, with $59 \%$ of its total CBD land devoted to streets and parking, of which $23.2 \%$ consists of parking lots and $.6 \%$ of garages. Even here the figures are not as devastating as they first appear. Although $23.2 \%$ of the total ground area of the Los Angeles central business district is occupied by parking lots, these lots occupy only $19.6 \%$ of the total area (that is, floor space plus ground area) in use. ${ }^{119}$ Even this lower figure may impress most observers as excessive, particularly in comparison with CBD land devoted to uses that are socially more desirable.

If the amount of land devoted to parking space is excessive, eliminating use of the automobile for work trips seems the best place to begin to restore the imbalance. Urban planners use the rule of thumb that work trips require half a parking space per vehicle while non-work trips require approximately one-seventh of a space per trip because of more frequent turnover. ${ }^{120}$ This means that elimination of one automobile formerly used as a commutation vehicle would liberate approximately a hundred square feet of CBD land for other uses. Alternatively, for each automobile removed from work trip service, parking would be provided for three-and-a-half trips.

That the automobile is a space waster can also be demonstrated by reference to the Interstate Highway Program. In response to the prevailing view of the 1960's, that the urban transportation problem was "congestion," limited-access highways were built into the heart of the cities "to relieve the pressure" on the outmoded street system. Such investments were justified on the basis of "savings in congestion costs"; it could be demonstrated with almost mathematical precision that the monetary value of the time saved by turnpike or thruway users justified the most massive investments. ${ }^{121}$ But the voracious appetite of

$119 \mathrm{~J}$. RAE, supra note 74, at 219, 220.

120 W. Smith \& Associates, Parking in the City Center 22 (1965).

121 In 1965 the average cost of building an urban mile of four-lane interstate highway was $\$ 3.7$ million, with the cost increasing astronomically to estimated costs of $\$ 50$ 
these highways for urban land gave rise to second thoughts about the program in more than one metropolitan area. ${ }^{122}$ Yet from a land use point of view, these limited access highways should have been preferable to the conventional street system. When complete, for example, the Los Angeles freeway will occupy $2 \%$ of available land to carry $50-60 \%$ of all motor vehicle traffic. The remaining traffic will be carried on local streets which occupy ten times as much space. ${ }^{123}$ In enacting the Urban Mass Transportation Act, Congress rejected this "efficiency" of the limited access highway because of its undesirable externalities, ${ }^{124}$ opting instead for a transportation mode more efficient in land use terms and less provocative of opposition: mass transit. ${ }^{125}$

Although the rational conclusion to be drawn from these oft-quoted figures would appear inescapably to favor rail or bus transit, it must be noted that the comparison is between respective capacities. While it is true that the average automobile occupancy rate for work trips is below capacity at 1.3 , it is also true that rail transit systems rarely operate at $100 \%$ of capacity. ${ }^{126}$ Second, to the extent that the preferred mass transit system involves the use of buses, its demands upon urban land may be as

million per mile for Boston's Central Artery and of more than $\$ 100$ million per for the Lower Manhattan Expressway. Tarpley \& Dake, supra note 85, at 246.

${ }^{122}$ See H.R. REP. No. 204, supra note 99, at 4.

${ }^{123} \mathrm{~J}$. RAE, supra note 74, at 221. (1964).

124 On the externalities, see L. Mumford, The Highway and the City 248-49

${ }^{125}$ The argument for mass transit in land use terms runs as follows: The area needed to move one person one mile is 1 square foot by rail, 3 square feet for a pedestrian, 10 square feet for bus travelers and 14-70 square feet for a private autoist. Another formulation indicates that the average freeway land has a capacity of 1,500 cars per hour. Even if every automobile contained five passengers, the maximum number of persons that could be transported in that lane would be 7,500 , compared with the $40-50,000$ person capacity of a single rail rapid transit line. A single track of a rail system can handle train headways of 1.5 minutes or 40 trains per hour. Assuming 10 cars per train, the capacity of a single track is 48,000 passengers per hour (assuming 120 passengers per car). The Sixth and Eighth Avenue subways in New York regularly carry peak hour loads of 61,500. See Roess, Existing Technology in Mass Transportation, in Transportation and Aging, supra note 13 , at 93 .

Bus rapid transit (exclusive right of way, not a reserved land, with 15-second headways, 50-seat buses, and 25 standees per bus) produces a capacity of 18,000 per hour. It is theoretically possible that capacity could be increased to 30,000 if stops were made out of the travel lane. Id. 97. Note, however, that to attain a 30,000 capacity would require 400 buses and drivers as opposed to a rail system of 25 trains and a labor force of 50 . See also MEYER, supra note 3, at 206 n.4 (non-stop bus lanes could handle up to 720 buses per hour).

${ }^{126}$ See Organization for Economic Cooperation and Development, Techniques of Improving Urban Conditions by Restraint of RoAd Traffic 19 (1973) [hereinafter cited as $O E C D]$. 
great if not greater than the status quo. Finally, it would do well to keep in mind the negative externalities that led to the rejection of the urban portions of the interstate highway system. That experience teaches that efficiency considerations should not override our intuitive judgments about preserving green space, attractive vistas, and cohesive neighborhoods. These "community objectives" may be as threatened by mass transit as they were by the highway program. ${ }^{127}$

\section{The Urban Mass Transportation ACT of 1964}

\section{A. The Act's Preference for Rail Rapid Transit}

As has been noted, the primary focus of the federal mass transportation program has been an attempt to divert the comimuter from his automobile. To accomplish this worthy objective, Congress has provided a program to "reinvigorate" mass transit by providing funds "to assist States and local public bodies and agencies thereof in financing (1) the acquisition, construction, reconstruction, and improvement of facilities and equipment for use ... in mass transportation service in urban areas and in coordinating such service with highway and other transportation in such areas." 128 Essentially, therefore, financing is made available for capital expenditures, a point made explicit in the definition of "eligible facilities and equipment" as "buses and other

${ }^{127} \mathrm{Cf}$. Trustees of Columbia College v. Thacher, 87 N.Y. 311 (1882), in which the New York Court of Appeals relieved the defendant of the burden of a covenant restricting the use of his land to residential purposes. The court applied the doctrine of "change in neighborhood conditions"- the "change" in this case being the construction of an elevated street railway on Sixth Avenue in front of the premises in question. Undoubtedly, the street railway was hailed in its day as a technological break-through which would put an end to "congestion" and "the urban transportation problem." The court found, however, that the railway had so depreciated the property that no "quiet and orderly people" would wish to reside in the neighborhood.

${ }^{128}$ Urban Mass Transportation Act of 1964, § 3(a), 49 U.S.C.A. § 1602 (Supp., Feb. 1975), amending 49 U.S.C. $\$ 1602$ (1970). The "mass transportation service" described in the Act is defined by a number of authorities. Section 12(c)(5) of the Act defines mass transportation as "transportation by bus, or rail or other conveyance, either publicly or privately owned, which provides to the public general or special service . . . on a regular and continuing basis." Id. \$ 12(c)(5), 49 U.S.C. $\$ 1608$ (1970). See MANUAL, supra note 6, at IIB-1-2. The original definition in the Act defined mass transportation as serving the public "over prescribed routes." Urban Mass Transportation Act of 1964, \& 9(d)(5), Pub. L. No. 88-365, \& 9(d)(5), 78 Stat. 302. This definition was believed to be "unduly restrictive" in light of changing technology. House CoMm. on Banking and Currency, Housing and Urban Development Act of 1968, H.R. Rep. No. 1585, 90th Cong., 2d Sess. 65-66 (1968) [hereinafter cited as H.R. REP. No. 1585]. 
rolling stock and real property including land . . .."129

Grant applications are placed in one of three groups depending on the size of the urban area. ${ }^{130}$ In the large system category, comprised of areas with $1,000,000$ population and over, a basic purpose is the diversion of the auto commuter to mass transit so as to relieve "congestion." ${ }^{131}$ Thereafter priority is given to projects

designed to reduce traffic congestion by utilization of UMTA capital grant funds in conjunction with the Federal Highway Administration's (FHWA) TOPICS (Traffic Operations Program to Increase Capacity and Safety) program and the Urban Corridor Demonstration Program, which is funded jointly by UMTA and FHWA. Examples of such projects include the use of exclusive or preferential streets, bus lanes, or expressway ramps . . . . ${ }^{\mathbf{3 2}}$

Priority is also given to projects "which are part of programs that demonstrate current use of, or proposed adoption of, noncapital intensive means by which to reduce traffic congestion," such as staggering of work hours, car pooling, increasing bridge and tunnel tolls, regulating parking, banning private automobiles from sections of the CBD during workdays, and increasing the supply of taxicabs. ${ }^{133}$ The so-called priority for

129 Urban Mass Transportation Act of 1964, § 3(a), 49 U.S.C.A. § 1602 (1970). On the distorting effects of capital grants, see Schultze, Sorting Out the Social Grant Programs: An Economist's Criteria, 64 Am. Econ. Rev. 181, 186-87 (1973); Tye, The Capital Grant as a Subsidy Device: The Case Study of Urban Mass Transportation, in Jornt Economic Comm., 93d Cong., 1st Sess., The Economics of Federal Subsidy Programs 796 (1973).

${ }_{130}$ Manual, supra note 6, at IIB-17 to - 18 .

${ }^{131}$ Id. IIB-18. See generally H.R. REP. No. 204, supra note 99, at 5-7.

As a precondition to federal funding, the applicant must indicate anticipated changes in the following criteria of congestion: "(1) peak-hour travel speeds of $20 \mathrm{mph}$ or less, (2) service at level D or lower (per HRB Special Report 87, Highway Capacity Manual, 1965), and (3) traffic volume-to-capacity ratio approaching one during a.m. and p.m. peak travel hours." MANUAL, supra note 6, at IIB-27. Service "D" level traffic flow is defined as an "unstable flow, with tolerable operating speeds being maintained though considerably affected by changes in operating conditions. . . . Drivers have little freedom to maneuver, and comfort and convenience are low, but conditions can be tolerated for short periods of time." Highway Research Board, Highway Capacity Manual 81 (1965). For downtown streets " $D$ " level service means traffic is moving at approximately 10 mph. Id. 334.

132 ManUAL, supra note 6, at IIB-23. See 23 U.S.C. \& 135 (1970), as amended, (Supp. III, 1973).

${ }^{133}$ Manual, supra note 6, at IIB-28. That the guidelines are sometimes not guidelines, and that the priority given to non-capital intensive measures is not always to be followed, is evident from the following statement: "It is recognized that some of the actions would be politically unacceptable without the precondition of improved transit. 
non-capital intensive means of reducing auto commuting, though provided for in theory, is not carried out in practice. ${ }^{134}$

Should an applicant succeed in gaining a priority sufficient to warrant access to funds, the federal program will provide $80 \%$ (formerly $\left.66^{2} / 3 \%\right)^{\mathbf{1 3 5}}$ of the "net project cost." The remainder is

For these reasons, this guideline is not a precondition to the selection of projects, but a basis for giving priority to projects in areas showing attention to the subject." McManus, supra note 83 , at 35 .

${ }^{134}$ The relative value of projects in alleviating congestion is measured by indicators such as the "daily passengers boarded per dollar of net project cost, daily passenger-miles per dollar of NPC, increase in passenger-miles per man-year, increase in passenger-miles per day." Manual, supra note 6, at IIB-23. To the extent that the use of these indicators is "not practicable," the following is the order of priorities: (1) additions to existing car fleet, (2) extension of existing lines, (3) construction of, and rolling stock for, new lines, including stations and access thereto, (4) replacement of existing cars, (5) improvements to existing stations. Id. IIB-29. These priorites, which are far simpler to apply, have nothing to do with "congestion" or "non-capital intensive means," but are in fact the real criteria by which decisions are made.

The elaborate controls over capital grants are resented by major transit-oriented cities, who believe "they are capable of determining priorities and projects better than the Federal Government...." E. Parker \& K. Kamrass, supra note 80, at 11.

On February 27, 1975, the author requested information from UMTA on the implementation of this policy and, in particular, the identification of projects in which "non-capital intensive means" were a significant feature. In its reply, UMTA noted that

[i]n reviewing applications for federal funding, consideration is given to those applicants that have incorporated good planning and use of non-capital intensive means to improve their systems. Funds are not made available solely because an applicant has instituted good management procedures. We agree, however, that perhaps greater recognition should be given to cities which institute these non-capital intensive means of improving their local system.

Letter from Urban Mass Transportation Administration to the author, Mar. 21, 1975, on file with the University of Pennsylvania Law Review. The only response to the request for specifics was a press release summarizing projects for exclusive bus lanes.

On August 1, 1975, UMTA published a "Notice of Proposed Policy" on "Major Urban Mass Transportation Investments." 40 Fed. Reg. 32546 (1975). The critical feature of the new policy is that "an analysis of transportation alternatives will be required as a condition of eligibility for federal assistance ...." (emphasis in original). One of the categories is "Improved Management of Existing Transportation System," in which "[a]ctions such as preferential treatment of buses on freeways and city streets, ... parking management, measures to reduce the use of automobiles in congested areas, . . . and other actions designed to make more efficient use of existing transportation facilities, should be considered as alternatives and supplements to the construction of new capital facilities." Id. 32547.

The indicia of priorities promulgated by the Administration for the large system category are similar to those for the medium system category. ManUal, supra note 6 , at IIB-27. In the small system category, including cities with a population below 20,000 , the administrative guidelines emphasize making bus systems economical and responsive to the needs of the transportation disadvantaged. Id. IIB- 19.

135 Urban Mass Transportation Act of 1964, § 4(a), 49 U.S.C.A. § 1603(a) (Supp., Feb. 1975). The $80 \%$ figure was considered equitable because the Interstate Highway Program provided $90 \%$ federal financing and other highway programs were $70 \%$ federally financed. See House Comm. on Public Works, Federal-Aid Highway Acr of 1973, H.R. REP. No. 118, 93d Cong., 1st Sess. 44 (1973) [hereinafter cited as H.R. Rep. No. 118]. 
to be provided from local sources. The statute indicates that "net project cost" is that "portion of the cost which cannot be reasonably financed from revenues." 136 This provision leaves room for considerable interpretation. An initial question is whether the "revenues" referred to are revenues generated by existing fare levels or whether it is open to the Administrator to contend that an applicant could "reasonably finance" a good portion of the total project cost if fares were raised. The statute prohibits the Secretary from regulating

in any manner the mode of operation of any mass transportation system with respect to which a grant is made under section 3 or, after such grant is made, to regulate the rates, fares, tolls, rentals, or other charges fixed or prescribed for such system by any local public or private transit agency. ... ${ }^{137}$

This section can be read to permit the Secretary to regulate fares before a grant is made. This seems to have been the congressional intent because the House Report notes in its discussion of net project costs that "[i]n determining fares the locality would be expected to establish reasonable rates which will attract sufficient riders for the assisted project . . . which will yield adequate revenues." 138

A second question is whether the applicant need consider total system revenues or only revenues to be generated by the proposed project. If the applicant is permitted to consider total system revenues, the amount that may be financed from them will normally be zero, because all major transit systems were operating at increasing deficits at the time of the law's enactment and still are. This was apparently the view of the Comptroller General, who noted that "if the administration's concept is fully implemented, most projects will receive Federal and non-Federal grants equal to nearly 100 percent of a project cost."139

136 Urban Mass Transportation Act of 1964, § 4(a), 49 U.C.S.A. § 1603(a) (Supp., Feb. 1975). The phrase "net project cost" was borrowed from the Urban Renewal Program. See Housing Act of 1949, 42 U.S.C. \& 1460(f) (1970).

${ }^{137}$ Urban Mass Transportation Act of 1964, § 12(e), 49 U.S.C. $\$ 1608$ (1970) (emphasis supplied).

${ }^{138}$ H.R. REP. No. 204, supra note 99, at 13. Grant applicants must provide a financial statement indicating, inter alia, "the means by which funds will be available to meet all prospective operating deficits for at least five years." MANUAL, supra note 6, at IIB-20, 24, 27 (1972). Applicants are advised that "identifying alternate levels of service and fares that would permit a break-even operation can be a useful analysis" in this regard. Id. IIB-20.

${ }^{139}$ Hearings, supra note 117 , at 41. 
To consider total system revenues in deciding financing capability would make nonsense of the limitation on federal financing. Yet the House Report in support of the bill indicated that in defining "net project cost," "the operating income of the entire local transit system will always be used in determining revenues and the need for Federal assistance." ${ }^{140}$ On the other hand, in another section of the same report, the majority uses as an illustration of the concept of net project cost the extension of the rapid transit line from Camden to Kirkwood, New Jersey, estimated to cost $\$ 50$ million. "It expects ... half of this amount from the fare box, and in such case the maximum Federal grant could not exceed about $\$ 17$ million (two thirds of the remainder)." ${ }^{141}$ The Administration has followed the canon of interpretation granting priority to the specific over the general to construe the intent of the draftsmen to mean that "net project cost" equals total project cost less "anticipated revenues" to be generated by the project. ${ }^{142}$ By the end of 1970, however, the House noted that "the gap between 'gross project costs' and 'net project costs' . . . is small and rapidly disappearing." ${ }^{43}$ By the end of 1972, the Department noted that there is "usually little difference between the gross and net project costs" and, in its cumulative report on grants approved under the program, listed projects in terms of their "gross" cost only, omitting the column for "net project cost" for "the sake of simplicity."144

The interpretation of the local portion provision of the project cost calculation has also had an interesting history. The stat-

${ }^{140}$ H.R. REP. No. 204, supra note 99, at 13.

${ }^{141}$ Id. 17. This calculation was obviously made considering only anticipated fares from the new project. Of course the Camden (Lindenwold) line is the only one in its system.

142 Manual, supra note 6, at IIB-2 to -3. But see id. App. 3, at 32 (sample format for a grant application). In calculating project financing, applicants are instructed to

[e]stimate that portion of the Gross Project Cost which can be financed from current revenues of the transit system. Please note that these estimates are to be based on current revenues of the entire transit system, including charter and incidental revenues, and not only that part to be assisted by this proposed project.

Id. App. 3, at 28.

${ }^{143}$ House Comm. on Banking and Currency, Urban Mass Transportation Assistance ACt of 1970, H.R. Rep. No. 1264, 91st Cong., 2d Sess. 4 (1970) [hereinafter cited as H.R. REP. No. 1264].

${ }^{144}$ Urban Mass Transportation administration, U.S. Dep't of Transportation, Approvals of Capital Grants and Loans i (1973) [hereinafter cited as UMTA Approvals]. The Department noted that a project usually generated revenues when it sold equipment being replaced by the project. Id. This seems a good distance from the original meaning of the concept. 
ute provides that the local portion shall be "in cash." 145 The purpose was to prevent local governments from meeting their twenty percent share by "tax forgiveness."146 One would have thought the phrase "in cash" rather unambiguous, but this has not been true in practice. The administrative rules provide that "[t]he local contribution should be in cash, but may, however, include the direct contribution to the project of labor, materials, land which has not previously been used for transit purposes, or other property of ascertainable value." ${ }^{147}$ Such in-kind contributions must, of course, be "necessary and reasonable for proper and efficient accomplishment of project objectives."148 The explanation for the cash/goods paradox may lie in a cryptic sentence in the House Report: "The committee wishes to point out that while the local one-third contribution [now one-fifth] must be met in cash, any public land or property or services necessary for a project would be included in gross project cost and paid for the same as private property."149 Presumably this means that the local cash requirement can be met by simultaneous bookkeeping entries.

The 1964 Act envisaged that the "cash" would come from public bodies. Senator Williams expressed the view that the way to get "state and local governments to come to grips with the problem, financially and otherwise," was to require that local costs be provided by public bodies. ${ }^{150}$ The provision was not, however, intended to exclude private transit bodies from participation in the program. The public grant recipient could lease facilities to a private operator or otherwise contract for such services. ${ }^{151}$ The Act was amended in 1968 to include the provision that " $[\mathrm{n}]$ ot more than 50 percentum of such remainder [i.e. the local or non federal portion of the project cost] may be pro-

14549 U.S.C. $\S 1603$ (1970), as amended, 49 U.S.C.A. $\$ 1603$ (Supp., Feb. 1975).

${ }^{146}$ H.R. REP. No. 204, supra note 99, at 12.

${ }^{147}$ MANUAL, supra note 6, at IIB-2 (emphasis supplied).

${ }^{148}$ Id. IIID-25.

149 H.R. REP. No. 204, supra note 99 at 13.

150 Testimony of Senator Williams before the Subcomm. of the House Comm. on Banking and Currency, May, 1961, quoted in Kohl, The Federal Urban Transportation Demonstration Program, 18 TRAfFic Q. 301 (1964).

151 Urban Mass Transportation Act of 1964, § 3(a), 49 U.S.C.A. $\S 1602$ (Supp., Feb. 1975), amending 49 U.S.C. $\S 1602$ (1970). See also H.R. REP. No. 204, supra note 99, at 12:

A grant would be made only to a public body which demonstrates that it has the legal, financial, and technical capacity to carry out the proposed project. The public body would not necessarily have to operate the transit facilities and equipment itself. It could provide for their operation by lease or other arrangement. 
vided from other than public sources . ..."152 The purpose of the amendment was to clarify Congress' intention that the participation of private enterprise be encouraged to "the maximum extent feasible."153 The amendment also provided for participation by private entities above the fifty percent level "in cases of demonstrated fiscal inability of an applicant." 154 This latter provision was stricken in 1970 because of the obvious reluctance of most communities to confess to "fiscal inability," a reluctance due in no small part to the effect of such a confession on bond ratings. ${ }^{155}$ The 1970 amendments also provided that the local contribution "may be provided in whole or in part from other than public sources ...."156 The ostensible purpose was once more to encourage private participation. The theory apparently was that a 50-50 partnership did not appeal to private sources whereas one hundred percent private capital in partnership with the federal government would. ${ }^{157}$

From the foregoing brief description, it is clear that the Urban Mass Transportation Act is broad enough to authorize remedial action for most conceptions of the urban transportation problem. Experience with congressional activity cautions, however, that the nature of a program is best ascertained by examining the actual appropriation and disposition of funds. The report of the Institute of Public Administration, which provided much of the data on which the Act was based, projected a total "needed" transit investment for the decade 1962-1971 at $\$ 9.8$ billion. ${ }^{158}$ Of this total, the report estimated that federal assis-

${ }^{152}$ Housing and Urban Development Act of 1968, Pub. L. No. 90-448, § 704, 82 Stat. 476.

${ }^{153}$ H.R. REP. No. 1585, supra note 128 , at 67 ( $\$ 704$ referred to as $\S 604$ in Report).

${ }^{154}$ Housing and Urban Development Act of 1968, Pub. L. No. 90-448, § 704, 82 Stat. 476. The amendment also indicated that to the extent the local share was provided by public or private transit systems, those funds could be provided "solely from undistributed cash surpluses, replacement or depreciation funds or reserves available in cash, or new capital .... Id. The stated purpose of this section was to prevent the use of revenues to cover local capital costs, especially new issues of revenue bonds. See H.R. REP. No. 1585, supra note 128 , at 67.

${ }^{155}$ See generally H.R. REP. No. 1264, supra note 143 , at 7.

${ }^{156}$ Urban Mass Transportation Act of 1964, § 4(a), 49 U.S.C. § 1603 (1970).

157 H.R. REP. No. 1264, supra note 143 , at 7 .

${ }^{158}$ This total was broken down as follows: (1) estimated costs of new transit or suburban rail systems in Atlanta, Los Angeles, San Francisco, and Washington; estimated costs of projected extensions of rail systems in Boston, Chicago, Cleveland, New York, and Philadelphia; and estimated costs of rehabilitating rights-of-way and structures of grade-separated and suburban rail systems- $\$ 5.5$ billion; (2) estimated costs of replacement and additional rolling stock $-\$ 3.3$ billion; and (3) provision for possible rail or bus grade-separated facilities- $\$ 1.0$ billion. L. Firch, supra note 84, at 55-57. 
tance "might run to $\$ 2.5$ to $\$ 3.5$ billion."159 Although Congress was clearly aware of these figures it anticipated that "a large part of the total capital cost can and will be met from the fare box." 160

Whether Congress really believed in the vitality of the "net project cost" concept and thus the viability of financing from the fare box, or whether, more plausibly, it just chose to proceed cautiously, the ensuing legislation authorized amounts of far more modest proportions than the Institute of Public Administration had proposed. The Act authorized $\$ 75$ million for fiscal year $1965, \$ 150$ million for fiscal year 1966 , and $\$ 150$ million for fiscal year $1967 .{ }^{161}$ The appropriations were even lower- $\$ 60$ million in fiscal year $1965, \$ 130$ million in each of fiscal years 1966 and $1967 .{ }^{162}$ Even at these low funding levels, the program was slow in getting started. In fiscal year 1965 only $\$ 50.7$ million in projects were approved and in fiscal year 1966 only $\$ 106.1$ million. ${ }^{163}$ In early 1966 a survey by a consultant to the Department of Housing and Urban Development indicated that the ten-year capital needs of mass transit systems for the decade 1966-75 would be $\$ 10.9$ billion. ${ }^{164}$ Again Congress responded modestly. In 1966 the Act was amended and authorized an additional $\$ 150$ million each for fiscal years 1968 and 1969. A later amendment authorized $\$ 190$ million for fiscal $1970 .{ }^{165}$

On October 15, 1969, a new report was submitted by the Institute of Public Administration projecting a capital investment estimate of $\$ 41.6$ billion for the period $1970-79$ for the twentynine largest urbanized areas. ${ }^{166}$ Congress did not back off in the

${ }^{159} \mathrm{Id}$. 226. This estimate was based on a program of federal subsidization of interest on locally issued transit authority bonds-a Public Housing Administration (PHA) type program.

${ }^{160}$ H.R. REP. No. 204, supra note 99, at 6.

${ }^{161}$ Urban Mass Transportation Act of $1964, \S 4(\mathrm{~b})$, Pub. L. No. 88-365, § 4(b), 78 Stat. 302, as amended, 49 U.S.C.A. $\$ 1603$ (Supp., Feb. 1975).

162 Senate Comm. on Banking and Currency, Urban Mass Transportation Amendments of 1966, S. ReP. No. 1436, 89th Cong,, 2d Sess. 3 (1966).

${ }^{163} I d .4$.

${ }^{164}$ This figure represented the total of projections of $\$ 8.6$ billion for eleven major metropolitan rail transit systems, over $\$ 1$ billion for possible future rail systems, and $\$ 1.3$ billion to replace buses that were more than sixteen years old. Id. 2-3.

${ }^{165}$ Act of Sept. 8, 1966, Pub. L. No. 89-562, § 1(a), 80 Stat. 715, as amended, 49 U.S.C. $\$ 1603(\mathrm{~b})$ (1970). Actual appropriations were $\$ 125$ million in fiscal 1968, \$175 million in fiscal 1969 , and $\$ 175$ million in fiscal 1970 .

${ }^{166}$ The total was broken down as follows: projected capital investment for planned improvements in existing rail rapid transit in New York, Chicago, Boston, Philadelphia, and Cleveland $-\$ 5.14$ billion; similar investments in suburban rail facilities-\$2.28 billion; additions and replacements to the bus supply- $\$ 705$ million; a busway in Bos- 
face of this staggering increase in projected needs. Instead it interpreted the increases as evidence of "a marked increase of interest among cities ... in improving urban mass transportation facilities as the Federal assistance program begins to show results." 167 In response Congress passed the Urban Mass Transportation Assistance Act of $1970 .{ }^{168}$ The preamble contains the congressional finding that "success will require a Federal commitment for the expenditure of at least $\$ 10,000,000,000$ over a twelve-year period . ..."169 To manifest the seriousness of its intent, Congress authorized and made available for obligation a total of $\$ 3.1$ billion from the date of enactment. ${ }^{170}$

ton- $\$ 150$ million (total- $\$ 8.27$ billion). Planned rail rapid transit systems in Washington, D.C., Los Angeles, Baltimore, Seattle, and Honolulu- $\$ 5.88$ billion; planned busway/guideway investments in Atlanta and Pittsburg- $\$ 1.29$ billion; and planned expenditures on the partially completed BART system in San Francisco- $\$ 1.2$ billion (total-\$8.37 billion). To these contemplated expenditures were added "high likelihood" expenditures on fixed rail systems in Detroit, Miami, and St. Louis of $\$ 5.5$ billion; "medium likelihood" expenditures for such systems in Cincinnati, Denver, and Buffalo, totaling \$2.14 billion; and "low likelihood" facilities in New Orleans and Sacramento at $\$ 1.2$ billion, for a total of $\$ 8.84$ billion. In addition, the total included $\$ 5.2$ billion for possible expenditures on busway/guideway systems in eight cities. Other projected expenditures on replacement or additional buses amounted to $\$ 2.9$ billion. An inflation factor of $25 \%$ brought the total to $\$ 41.9$ billion. F. Graves \& R. Rechel, Estimates of Prospective Capital Investment in Urban Public Transportation, Oct. 15, 1969. But see N.Y. Times, Mar. 18, 1974, at 58, col. 1 (St. Louis "scraps" 86-mile system which would have cost $\$ 2$ billion but "generated no public enthusiasm").

${ }^{167}$ H.R. REP. No. 1264, supra note 143 , at 4.

${ }^{168}$ Act of Oct. 15, 1970, Pub. L. No. 91-453, §§ 1-14, 84 Stat. 962, amending Urban Mass Transportation Act of 1964, Pub. L. No. 88-365, $\S \S 1-12,78$ Stat. 302 (codified at 49 U.S.C. $\$ \S 1601-12(1970))$.

${ }_{169} 49$ U.S.C. $\S 1601$ la (1970).

The considerations that went into determining the appropriate level of funding appear to have been based principally on the financing of new rail transit systems and the extension of existing systems. The 1970 House Report, H.R. REP. No. 1264, supra note 143 , is ambiguous on the point. It first indicates that capital expenditures on rail systems were projected at $\$ 10$ billion for 1966-75. Thereafter the report notes that "cost escalation" has required an upward adjustment of this figure to a total of $\$ 11.8$ billion. In the next paragraph, the report indicates that "more recent estimates . . . place 10-year requirements at between $\$ 28$ and $\$ 34$ billion ... ." Id. 4. It is unclear whether these "more recent estimates" encompassed all mass transit needs or only those rail system needs referred to in the two preceding paragraphs. The latter alternative makes more sense grammatically. In the next paragraph the report notes that "[u]nless the Federal Government is prepared to foreclose any support for the capital costs of fixed-rail systems, an estimate of about $\$ 15$ billion in total capital requirements for urban public transportation systems over the next decade would seem to be reasonable for policymaking purposes." Id. In light of what had been said in the text preceding this sentence, it seems likely that most, if not all, of the $\$ 10$ billion provided for in the 1970 Act was intended to pay for rail transit.

${ }^{170}$ Urban Mass Transportation Assistance Act of 1970, § 4(c), 49 U.S.C. $\S 1603$ (c) (1970). 
As soon as funding had begun on the large scale mandated by the 1970 Act, even higher projections were made. The National Transportation Report published in 1972 estimated mass transit needs for the period 1970-1990 at "about $\$ 63$ billion"171 and the Department of Transportation in 1973 estimated a need for over $\$ 50$ billion over the next ten years. ${ }^{172}$ As of February 28, 1975, \$1.636 billion in capital grant funds had been approved. ${ }^{173}$

A provision of the Federal-Aid Highway Act of 1973 required the Department of Transportation to study future public urban mass transportation needs and financing. ${ }^{174}$ That study, completed in the summer of 1974, projected a capital investment program for the period $1972-1990$ of $\$ 58.2$ billion (1971 dollars)

171 H.R. REP. No. 118, supra note 135 , at 3.

${ }^{172}$ See, e.g., U.S. Dep't of Transportation, Background Information on the Urban Mass Transportation Administration (1973).

${ }^{173} 71$ Metropolitan, Sept.-Oct. 1975, at 22. The effort to ensure that authorized sums are made available has been directed at "tapping" the Highway Trust Fund. The summer of 1973 saw the first marriage of the federal system for highways and the Federal Mass Transportation Assistance Program. There are four federal aid systems dealing with highways: the primary system, the urban system, the secondary system, and the interstate system. 23 U.S.C. $\$ 103$ (a) (1970). All of these systems are financed from the Highway Trust Fund. Their relative importance is indicated by the following levels of annual authorizations: interstate system, $\$ 3$ billion; primary system, $\$ 700$ million; secondary system, $\$ 400$ million; urban system, $\$ 700$ million. The Federal-Aid Highway Act of 1973 provides that a state may use its pro rata share of the urban system funds for purchase of buses, up to $\$ 200$ million in fiscal 1975. 23 U.S.C.A. $\$ 142(a)(2)$ (Supp., Feb. 1975), amending 23 U.S.C. $\$ 142$ (a) (1970). The formula for the pro rata share in 23 U.S.C. $\S 104(b)(6)$ is the ratio of the population of the state to the population of the urbanized areas of the United States.

Once divided up, the sums made available under the 1973 legislation are insignificant. Maximum estimates run as follows: California cities, $\$ 96$ million; Illinois cities, $\$ 49$ million; Massachusetts cities, $\$ 27$ million. See Wall St. J., Aug. 7, 1973, at 14, col. 5-6. See also remarks of Frank C. Herringer, UMTA Administrator, at the Fall Assembly of the Southern California Association of Governments, Sept. 13, 1973 (California's share, \$77 million; Los Angeles' share, $\$ 42$ million). The significance of the 1973 Act, however, is that funding comes from the Highway Trust Fund, whereas the UMTA appropriations are charges on the general revenues.

The 1973 Act also permits a state to withdraw planned segments of interstate highway and substitute non-highway public transportation projects with $80 \%$ federal financial participation. 23 U.S.C.A. \$103(e)(4) (Supp., Feb. 1975).

In an interview in April, 1975, UMTA Administrator Herringer indicated that only two grants, both for the purchase of buses, had been made under the provisions of the 1973 legislation. The two grants were about $\$ 33$ million to New York City and \$1.6 million to East St. Louis, N.Y. Times, Apr. 21, 1975, at 48, col. 4. Only three other applications, totaling $\$ 3.6$ million, were pending at that time. Administrator Herringer indicated that the causes of the "disappointing" results were the 30-70 state-federal formula (as compared to the 20-80 formula under the UMTA grant program) and "resistance from [state] highway authorities."

${ }^{174}$ Federal-Aid Highway Act of 1973, § 138, Pub. L. No. 93-87, 87 Stat. 270. 
for all urbanized areas. ${ }^{175}$ The 1973 legislation also increased the contract authority under the grant program from $\$ 3.1$ to $\$ 6.1$ billion. ${ }^{176}$ The National Mass Transportation Assistance Act of 1974 increased this authority to $\$ 10.925$ billion. ${ }^{177}$

That legislation also added a new dimension to the federal program. Under the 1974 Act the Secretary has contract authority up to $\$ 3.975$ billion, to be expended on either construction projects or deficit underwriting, on a scale beginning with a maximum of $\$ 300$ million in fiscal 1975 and increasing to $\$ 900 \mathrm{mil}-$ lion by fiscal $1980 .{ }^{178}$ These funds are to be distributed among the states in the following manner: half multiplied by the ratio of the urbanized population of the state to the urbanized population of the United States, and half multiplied by this ratio and weighted according to the number of inhabitants per square mile. ${ }^{179}$ Funds so apportioned are then available for use for up to eighty percent of construction costs or up to fifty percent of the operating expenses of a public mass transportation system. ${ }^{\mathbf{1 8 0}}$

Our interest in these figures is twofold. First, they establish that the federal commitment to urban mass transportation is significant and increasing rapidly. Second, the figures reveal the nature of the actual federal program as opposed to the wide range of possible options offered by the 1964 Act and administrative information manuals. The figures show unequivocally

175 U.S. Dep't of Transportation, A Study of Urban Mass Transportation NeEds and Financing I-3 (1974) [hereinafter cited as Study].

A 1973 report for UMTA suggested the adoption of a long-range goal of a bus or rail seat for every car commuter by the year 2000. See U.S. DEP'T OF TRANSPORTation, INTEgRation of Transit Systems ix (1973). The estimated capital cost would be $\$ 120$ billion. Id. $\mathrm{x}$. Of this amount $\$ 2.5$ billion would be spent for buses which would carry an estimated 10 million former commuters. $\$ 118$ billion would be spent on rapid rail and light rail facilities which would carry 22 million former commuters. Id. 20.

${ }^{176}$ Urban Mass Transportation Act of 1964, \& 4(c), 49 U.S.C. § 1603(c) (Supp. III, 1973), as amended, 49 U.S.C.A. \$ 1603(c) (Supp. Feb. 1975).

17749 U.S.C.A. § 1603(c) (Supp. Feb. 1975).

${ }^{178} I d$. $\& 1604(\mathrm{c})(1)$.

At the time the law was drafted, operating deficits of the nation's transit systems were at a rate of $\$ 360$ million per annum. Senate Comm. on Banking, Housing, and Urban Affairs, Emergency Commuter Relief Act, S. Rep. No. 361, 93d Cong., 1st Sess. 2 (1973).

179 Urban Mass Transportation Act of 1964, § 5(b)(1); 49 U.S.C.A. § 1604(b)(1) (Supp., Feb. 1975). This formula is the Administration proposal. The Senate alternative, allocation by revenue passenger and vehicle-miles, was abandoned because "they were not reliable ascertainable numbers and were potentially susceptible to manipulation." House-Senate Conference Comm., Conference Report, S. Rep. No. 1288, 93d Cong., 2d Sess. 15 (1974).

${ }^{180}$ Urban Mass Transportation Act of 1964, § 5(e), 49 U.S.C.A. § 1604(e) (Supp., Feb. 1975). 
that the main thrust of the Act is to assist in the improvement, extension, and development of rail rapid transit. ${ }^{181}$ Moreover, it seems likely that the percentage allocated to rail transit systems has been held down by the long lead time required to bring rail proposals to the point of funding and by the now eliminated statutory requirement that not more than $12.5 \%$ of the total funds authorized under the law be used in any one state. ${ }^{182}$ Finally, the 1974 provision for federal subsidy of operating deficits is aimed primarily at assisting cities with existing fixed rail facilities. ${ }^{183}$ This high proportion of funding for rail rapid transit has occurred in the face of ostensible administrative priorities for non-rail modes. ${ }^{184}$

\section{B. The Basis for the Act's Preference for Rail Rapid Transit}

At the outset, it would appear that the de facto preference for rail rapid transit is sound. Rail rapid transit is potentially the most efficient form of urban land transportation because it can carry the greatest number of people per hour along a given traffic corridor. If operated underground, as are most such systems, it could be the least obtrusive form of urban transportation system. Because it generally has exlusive use of its traffic lanes, it is potentially the fastest form of urban mass transportation. Finally, rail rapid transit can be easily adapted to recent technological advances, such as technology developed by the space program. It is the mode with the most potential for adaptation of the labor-saving techniques of automation. These potential advantages of rail rapid transit, however, do not reflect the actual situation.

181 Ninety percent of the 1961 total estimate was earmarked for investment in rail transit. The 1966 up-dating provided $88 \%$ of the total for rail rapid transit. The 1969 projection of $\$ 41.6$ billion was based on an allocation of $70 \%$ of this total to existing, planned, or proposed rail rapid transit. And the 1974 projection of $\$ 58.2$ billion investment between 1972 and 1990 consists of a $\$ 43.9$ billion investment in rail transit. See text accompanying notes $158-78$ supra (calculations by author). Moreover, over $66 \%$ of the approved capital grants made under the program by December 31, 1973, went to rail projects with an estimated $40 \%$ going to rail rapid transit. The figure for rail totals was supplied by the UMTA Public Affairs Office. The figure for rail rapid transit was calculated from data in UMTA APPRovals, supra note 144. The UMTA breakdown is by state and recipient, with brief descriptions of projects. In all cases in which project descriptions included rail and non-rail features, the figures were not included in the percentages given in the text.

18249 U.S.C. $\S 1611$ (1970), as amended, 49 U.S.C.A. $\$ 1611$ (Supp. Feb. 1975).

${ }^{183}$ See Miller, Financing Mass Transit: Mobility is Among the Assets, 76 TECHNOLogy REv., Dec., 1973, at 45, 46-47.

${ }^{184}$ Text accompanying note 133 supra. 


\section{Potential Benefits Examined}

\section{a. Cost}

The principal problem presented by the ability of rail rapid transit to move sixty thousand passengers per hour in one traffic corridor is that few cities can generate that volume of traffic. ${ }^{185}$ It can be argued, however, that assuming the land needed for one lane of limited access highway is approximately the same as that needed for one line of rail transit, the latter would be more

185 To generate the volume of traffic needed for a minimally successful rail transit corridor, a central city must have a population density of 14,000 per square mile. New York meets this standard easily with a central city density of 26,343 per square mile. The only other major American cities with densities of this magnitude are Chicago, 15,126; Philadelphia, 15,164; and Boston, 13,936. Bureau of The Census, U.S. Dep'T of Commerce, 1 Census of Population 1-187 to -188 (Table 35) (1972). It is often forgotten in citing the success of new rail transit systems in Canada that Montreal has a density of 9,300 per square mile and 26,400 in the central city, and that Toronto has 8,200 per square mile and 20,580 in the central city. R. BuEL, supra note 101 , at 187.

The extension of Boston's "Red Line" rapid transit system to the South Shore took it through an area with an average density of 1,300 persons per square mile. It therefore comes as no surprise that its average one-way ridership in April, 1972 was 11,092 passengers per day. See Metropolitan Area Planning Council, South Shore Rail Rapid Transit Extension, Preliminary Impact Study III-5, V-1 (1973).

Bus rapid transit (on exclusive rights of way) requires a population density of 14,000-20,000 per square mile, $C B D$ employment of at least 100,000, daily CBD destinations of at least 300,000 , and a corridor generating 70,000 persons per day by all modes. See Roess, supra note 125 , at 97 . For a detailed analysis indicating that a bus rapid transit system would be a poor investment for Milwaukee because of a lack of density and traffic volume, see Sawicki, Break-Even Benefit-Cost Analysis of Alternative Express Transit Systems, 8 J. Transp. Econ. \& Policy 274 (1974).

Commercial bus service is economically viable where there is a volume of 200 round trips per square mile daily. To achieve this goal the residential population density level must be at least 10,000. See Markovitz, supra note 14, at 79 .

New York is the only city in which actual hourly volume per transit track exceeds 40,000. See J. RaE, supra note 74, at 282 (Table 13.2). See generally A. LANg \& R. Soberman, Urban RaIl Transit 78-84 (1964). Figures for evening traffic volumes published in 1965 indicate that the "approximate number of persons leaving the central business district per peak hour in an average corridor" were as follows: New York -above 60,000; Chicago-30,000-40,000; Philadelphia, Boston, and Washington, D.C. -20,000-30,000; Los Angeles and San Francisco-13,000-20,000. Although approximate, these figures are probably higher than average, because the evening peak demand generally exceeds the morning peak and, more significantly, because many of the vehicles and persons counted as crossing the CBD border outbound were passing through the central business district. See MEYER, supra note 3, at 86-87.

Another rule-of-thumb measure of rail rapid transit viability is the degree of employment concentration in CBD's. Of total employment in the New York City SMSA, $69.1 \%$ of the jobs were located in the central city according to the 1970 census. On the other hand, central San Francisco employed only $25.2 \%$ of the SMSA work force; central Washington, 27.1\%; central Atlanta, 35.3\%; and central Boston, 23.1\%. See Sagner, The Impact of the Energy Crisis on American Cities Based on Dispersion of Employment, Utilization of Transit, and Car Pooling, 8 TransP. Research 307, 308 (Table 1) (1974). This would seem to explain the perpetual transit deficits in Boston and San Francisco and the foolishness of constructing fixed rail systems in Atlanta and Washington. 
efficient whenever the traffic volume exceeded 1,500 per hour. The difficulty with this argument is its failure to cope with the issue of costs. The latest available figures indicate that a rail rapid transit line requires a minimum peak-hour load of 12,000 passengers per hour to break even. ${ }^{186}$ These figures indicate that if a new transit line is built in Los Angeles or San Francisco, virtually one hundred percent of the present traffic along that corridor would have to switch to rail rapid transit to make the line economically viable. Even the best run lines may lose money if traffic volume is insufficient. ${ }^{187}$

The land use efficiency of rail rapid transit is thus purchased at a heavy cost because deficits must be funded from resources that might be devoted to other, equally "worthy" uses. The staggering level of the costs of rail rapid transit is indicated by 1973 estimates that the cost of carrying passengers on a rail rapid transit system was 24.6 cents per passenger mile, while the same trip by bus would cost 8.6 cents per mile. ${ }^{188}$ The private and public costs of a similar trip by auto were estimated at 26.4 cents per mile. With one occupant, the private cost of driving was roughly fifty-five percent of the cost of rail transit.

\section{b. Speed}

The speed advantage of rail rapid transit also diminishes upon examination. The Bay Area Rapid Transit (BART) in San Francisco, the newest rapid transit system in the United States,

${ }^{186}$ See Lago, United States Subway Requirements 1968-1990: Projections and Benefits, 23 TRAFFic Q. 71, 80 (1969) ("[M]inimum level for feasibility seems to be the order of peak-hour passenger volumes at maximum load points of 15,000 persons . . . ."). But see Tarpley \& Dake, supra note 85, at 255 (in Cleveland, volume of 7,200 per track covers operating costs and amortization of rolling stock).

187 For example, in 1970 the Chicago Rapid Transit had an average revenue per passenger (fare) of $47 c$ and an average cost per passenger of $52 \epsilon$. Yet, the Chicago rapid transit was the most efficiently run system in the country with a cost per car-mile (a standard measure of efficiency) of $\$ 1.23$. Boston's Massachusetts Bay Transit Authority (MBTA), on the other hand, had a cost per car-mile of $\$ 3.59$ (the highest in the United States) yet a cost per passenger of only 416 . The difference was passenger volume, with Chicago generating only 2.05 revenue passengers per car-mile and Boston generating 7.39. See Economic Characteristics, supra note 9, at 2-23, 2-24. In all cases, however, costs exceeded fare levels. See also Urban Mass Transportation Administration, U.S. Dep't of Transportation, Characterisitcs of Urban Transportation Systems 2-6 (Table 5) (1974) (1971-72 operating costs for six United States rail rapid transit systems ranged from $\$ 1.01$ to $\$ 2.79$ per car-mile) [hereinafter cited as URBAN TRANSPORTATION Systems]. In London the cost of running a bus system is about 1.25 new pence per passenger-kilometre. See RoAd Research Group, Organisation for Economic Cooperation and Development, Optimisation of Bus Operation in Urban Areas 12 (1972) [hereinafter cited as Bus OPTIMISATION].

${ }^{188} \mathrm{~J}$. Reed, Comparison of Urban Travel Economic Costs, Feb., 1973, at A-20. 
was designed to achieve maximum speeds of eighty miles per hour and operating speeds approximating forty-five miles per hour. Such speeds, however, are less a function of equipment than of the distance between stations. BART will attain an average speed of forty-five miles per hour only because its stations are spaced an average of 2.3 miles apart. (Because the maximum rate of acceleration and deceleration that "avoid[s] jerking passengers about" is four miles per hour per second, the maximum average speed for a line with stations spaced one mile apart is thirty-five miles per hour, assuming an in-station stopping time of twenty seconds.) ${ }^{\mathbf{1 8 9}}$ The Toronto subway, with equipment almost as modern as BART's, averages nineteen miles per hour because its stations are spaced .5 miles apart. ${ }^{190}$ London's Victoria Line, built in the 1960's, averages 24.2 miles per hour with stations spaced an average of .87 miles apart. ${ }^{181}$

The dilemma, then, is clear. To attain a speed level that will give mass transit a clear advantage over automobile commuting, proximity of stations to trip destinations must be sacrificed. Because there are only four BART stops in downtown San Francisco, the BART rider may have to change vehicles after leaving BART, destroying BART's time advantage. At the other end of the line, the distance between stations means that the feeder-haul portion of the trip must be longer, again limiting if not eliminating the time advantage. ${ }^{192}$ Even if faster line-haul speeds could be achieved, findings generated by a mathematical model, which simulates the demand for transit service for work trips, indicate that such trips exhibit twice the elasticity with respect to time on access facilities (-.709) than on line-haul facilities (-.39). ${ }^{193}$ Riders to work would rather have faster feeder service than fast linehaul service, exactly the opposite of what they are being offered by the Act. ${ }^{194}$

${ }^{189}$ See Rae, supra note 81 , at 87 . See also URBAN Transportation SYSTEMS, supra note 187 , at $2-2$.

${ }^{190}$ Roess, supra note 125, at 94 (Table 1).

${ }^{191}$ See Smith, An Economic Comparison of Urban Railways and Express Bus Services, $7 \mathrm{~J}$.

Transp. Econ. \& Policy 20 (1973).

192 Id. 30.

One study indicates that in a typical bus trip, in-motion time consumes only $41 \%$ of trip time. R. Buel, supra note 101, at 185. See also Bus Optimisation, supra note 187, at 12.

${ }^{193}$ See G. Kraft \& T. Domencich, supra note 85, at 10-11.

${ }^{194}$ One apparent way out of this difficulty is to provide parking facilities at mass transit stations so that the auto commuter will provide his own feeder service. BART plans to make available a total of 35,000 spaces for its park-and-ride program. Park-andride facilities have been provided at many outlying rail rapid-transit stations with mixed results. See Bailey \& Dimitriou, The Commuter and "Park and Ride", 26 TRaffic Q. 561, 562 


\section{c. Labor Savings}

Rail rapid transit is considered the most promising means by which public transportation systems can control their burgeoning labor costs. Although the total number of employees declined from 242,000 in 1945 to 138,420 in 1972 , the industry wage bill more than doubled in the same period, with the average annual wage increasing from $\$ 2,612$ to $\$ 10,515$. The industry has been plagued by low productivity and "feather-bedding." 195 One can understand why an employer in this situation would favor a more capital-intensive technology.

The prospective labor savings offered by rail rapid transit may, however, prove illusory. A recent study of rail rapid transit systems in six European cities reveals a median value of 6.8 staff per car in peak service as against a median of 3.8 for eleven bus systems. ${ }^{196}$ Even if rail rapid transit is the more efficient consumer of labor, as states the conventional wisdom, the laborsaving technology that will lead to the savings has yet to be developed. The failure of the system developed for BART is common knowledge. Even if the hardware did exist, the labor savings would not occur immediately because section 13(c) of the Act provides that "fair and equitable arrangements" to protect employees affected by an UMTA grant shall be a condition of assistance. ${ }^{197}$ This provision has worked to increase labor costs.

(1972). One of the reasons park-and-ride facilities frequently fail to live up to expectations is that a substantial part of commuting costs are incurred in the drive to the station. See Meyer, supra note 4, at 44 . Moreover, "transit riders who drive to and park at transit stations would prefer to drive all the way to Boston if parking were inexpensive and readily available." Mass Transportation Commission Staff, Mass Transportation in Massachusetts, in URBan Mass Transportation Administration, U.S. Dep'T of Transportation, 1-2 Urban Mass Transportation Abstracts 74 (1972) [hereinafter cited as Abstracts].

${ }^{195}$ The MBTA in Boston presents perhaps the classic case of the industry's labor troubles. MBTA employees belong to 27 unions, each with an exclusive jurisdiction. An example of the kind of fractionalization that can result is the "white line rule" which prohibits a bus driver from taking his vehicle past a white line in the repair yard. From there on, the task of moving the vehicle becomes the job of various maintenance personnel who apparently spend up to $20 \%$ of their time moving vehicles. See Boston Globe, Feb. 25, 1973, at 49, col. 4 .

Another example is the collective bargaining agreement between the Transport Workers Union and the.New York Metropolitan Transportation Authority in 1972 which provided, inter alia, for retirement at half pay after 20 years. In addition to its direct financial cost, this provision has caused a "crippling depletion of experienced personnel." Beggs, Introduction to Urban Transportation Needs, in URBan Transportation NeEds 10 (1972). See N.Y. Times, July 27,1975 , $\S 1$, at 1 , col. 1 .

${ }^{196}$ See Smith, supra note 191 , at 23.

${ }^{197}$ Urban Mass Transportation Act of 1964, § 13(c), 49 U.S.C.A. § 1609(c) (Supp. Feb. 1975) provides: 
As part of its "fair and equitable arrangement," employees of transit systems whose jobs were eliminated by San Francisco's BART system had to be hired by BART at their existing salaries, which were above those of BART employees doing similar work. The union demanded that all BART employees' salaries be raised to the higher level. When BART refused, 1,100 of the 1,375 BART employees struck. ${ }^{198}$

\section{d. Diversion of Automobile Traffic}

The available data confirm that new rail rapid transit facilities are unlikely to make significant inroads in the number of automobile commuters. ${ }^{199}$ In the cases of the Yonge Street subway in Toronto and the Congress Street Rapid Transit Line in Chicago, both built in the 1950's, over eighty-five percent of the patronage came from existing mass transit patrons. ${ }^{200}$ The most recent data on the impact of the Yonge Street subway indicate an average increase of one percent per year in the number of vehicles entering the downtown area during the morning peak between 1955 and $1970 .{ }^{201}$ The project to extend Boston's

It shall be a condition of any assistance under this chapter that fair and equitable arrangements are made, as determined by the Secretary of Labor, to protect the interests of employees affected by such assistance. Such protective arrangements shall include, without being limited to, such provisions as may be necessary for (1) the preservation of rights, privileges, and benefits (including continuation of pension rights and benefits) under existing collective bargaining agreements or otherwise; (2) the continuation of collective bargaining rights; (3) the protection of individual employees against a worsening of their positions with respect to their employment; (4) assurances of employment to employees of acquired mass transportation systems and priority of reemployment of employees terminated or laid off; and (5) paid training or retraining programs. Such arrangements shall include provisions protecting individual employees against a worsening of their positions with respect to their employment which shall in no event provide benefits less than those established pursuant to section $5(2)(f)$ of this title. The contract for the granting of any such assistance shall specify the terms and conditions of the protective arrangements.

The Secretary's determination as to what is "fair and equitable" is not judicially reviewable. See Kendler v. Wirtz, 388 F.2d 381, 383 (3d Cir. 1968).

There is an obvious contradiction between $\$ 13(c)$ and the theory of the capital grant form of assistance to local transit systems, one of whose attractive features was supposed to be an avoidance of "featherbedding" and "outrageous wage claims." Tye, Economics of Urban Transit Capital Grants, in PRICE-SUBSIDY Issues, supra note 62, at 30, 32.

${ }^{198}$ N.Y. Times, July 18, 1973, at 74, col. 1 . The strike is an extremely formidable weapon in the hands of transit employees. See, e.g., N.Y. Times, Dec. 9, 1973, § 1, at 19, col. I (effect on Christmas shopping "catastrophic").

${ }_{199}$ Projections of the impact of a $\$ 58$ billion investment in mass transit between 1972 and 1990 concede that there would not be "a significant diversion from automobile travel." STUDY, supra note 175, at I-4.

${ }^{200}$ See MEYeR, supra note 3, at 79. See also J. RAE, supra note 74, at 88.

201 See U.S. Dep't of Transportation, Coordination of Urban Development and 
Massachusetts Bay Transit Authority (MBTA) to Quincy and Braintree, which cost $\$ 111$ million, is estimated to have diverted under 1000 vehicles per day from parallel roadways (particularly the Southeast Expressway, which carries over 100,000 vehicles per day). ${ }^{202}$ The 1968-1969 extension of Cleveland's rapid transit system to the airport has reduced the automobile volume at peak hours on the downtown end of the parallel expressway by "at most . . 125 vehicles per lane per hour." 203 This reduction of less than ten percent of the traffic volume permits an estimated saving of no more than thirty seconds per trip. Surveys taken after the opening of the trans-bay tunnel in San Francisco indicate that BART has had at most a negligible effect on auto commuting into the city. ${ }^{204}$

The only evidence of a decline in auto traffic accompanied construction of the Lindenwold Line between Philadelphia and southern New Jersey, which operates parallel to the Ben Franklin Bridge. Since the line came into operation in February, 1969, peak hour traffic volumes on the bridge have declined about six percent. In 1969, an average of 13,446 vehicles crossed the Bridge into Philadelphia during the morning rush hour; in 1972 the average was down to $12,765 .{ }^{205}$

\section{The Argument for Rail Rapid Transit Rebutted}

Assuming that new or revitalized rapid transit systems cause some auto commuters to switch to mass transit, what is the

the Planning and Development of Transportation Facilities 116 (1974). A similar result obtained in Montreal where the Metro resulted in "no appreciable difference in private car trips to downtown." The net effect of the Metro was to enable more people to enter the downtown at the peak. Id. 126.

202 Remarks of George Hilton, Former Chairman of Task Force on Transportation Policy, on "The Advocates," Jan. 25, 1973 (Transcript at 13); AAA Newsletter, Summer, 1973, at 8. See also Metropolitan Area Planning Council, supra note 185 at VI-1: "The major conclusion ... is that the transit extension has neither reduced total inbound ADT nor has it reversed the trend of increasing peak hour volumes. However, the traffic surveys indicate that the new transit extension has reduced the peak hour volume rate of increase." As the above suggests, the number of cars entering Boston from the extension service area increased following the opening of the extension. See id. VI-7. See also Governor Francis W. Sargent, Policy Statement on Transportation in the Boston Region, Nov. 30, 1972.

${ }^{203}$ Wohl, Analysis and Evaluation of the Rapid Transit Extension to Cleveland's Airport, in Public Transportation and Passenger Characteristics 12, 21 (Highway Research Record No. 471, 1972).

${ }^{204}$ Trouble in Mass Transit, 40 Consumer Reports 190, 191 (1975); see U.S. Dep'T of Transportation, Carpool Incentives and Opportunities 29 (1975) (vehicular traffic across bridge reduced $6 \%$ ).

${ }^{205}$ Allen, The Impact of the Philadelphia-Lindenwold Rapid Transit Line on Automobile Traffic, 28 Traffic Q. 21, 29 (1974). The author goes on to make the somewhat Parkin- 
measure of success? The champions of rail rapid transit agree that the answer lies in a rough cost-benefit analysis. ${ }^{206}$ Their most formidable argument for rail rapid transit is the higher cost of the alternatives. The Atlanta Region Metropolitan Planning Commission estimated in 1959 that by 1970 , without changes in the public transit system, Atlanta would need 120 lanes of expressway capacity and twenty-eight lanes of downtown connector capacity. Construction of this capacity would decimate Atlanta. Moreover, in 1960 the cost per lane per mile was one million dollars, or $\$ 120$ million per mile for the expressway lanes alone. It was easy to conclude that a 64.9 mile rail-based rapid transit system, at a cost estimated at $\$ 421$ million in 1967 prices, was a bargain. $^{207}$

It was estimated that San Francisco would need forty additional lanes of freeways and 36,000 additional downtown parking spaces without BART. The estimated cost of construction of these facilities was easily twice the cost of BART. The State Highway Department stated that even if funds were available, it could not build highways fast enough "to take care of the growing needs of the district." And one of the attractions of the Lindenwold line is that "[w]ith the ultimate capacity equal to more than two four-lane expressways the Lindenwold line cost only one-quarter as much."208 The 1963 Hearings that led to the Urban Mass Transportation Act of 1964 are replete with similar stories of cities threatened with being paved over at astronomical cost. ${ }^{209}$

On a more sophisticated plane are the "social cost" or "externality" arguments, ranging from general comparisons of the number of automobile fatalities with the number for rapid

sonian argument, see note 194 supra, that the true measure of diversion is the number of park-and-ride passengers $(4,776)$ currently using the line.

${ }^{206}$ E.g., Governor Francis W. Sargent, Policy Statement on Transportation in the Boston Region, Nov. 30, 1972, at 16: "Throughout the region, transit investments which extend existing lines to the perimeter of the high density zone and to connections with major highways appear to be exceptionally cost effective in terms of the transit service they provide to the residents of the region and their effect on auto mommutation to the core." See Address by President Ford to the Sixth International Conference on Urban Transportation, Sept. 8-10, 1974, in Official Proceedings: Marketing Urban RENAISSANCE 41, 44 (1974) ("Investments in local mass transit systems must have reasonable cost to benefit ratios or relationships."); UMTA Notice of Proposed Policy, 40 Fed. Reg. 32546 (1975).

${ }^{207}$ See Tarpley \& Dake, supra note 85, at 257.

${ }^{208}$ Klauder, The Lindenwold Line, 25 TRAFFic Q. 323, 334 (1971).

${ }^{209}$ For a cost-benefit analysis of a "free transit" proposal in which the "benefits" consist primarily of foregone investment in highway capacity and "time savings," see Baum, Free Public Transport, 7 J. Transp. Econ. \& Policy 3, 15 (1973). 
transit to the kind of examination made in Part III of this Article. ${ }^{210}$ Such arguments reach their zenith in the "congestion costs" thesis. ${ }^{211}$ By reducing congestion, the time consumed in remaining trips is decreased; by multiplying the time saving on each trip by some assumed time value (in dollars), one can arrive at a figure representing the "savings" or "benefit" of a given transportation investment. ${ }^{212}$ This formula was used to extend the interstate highway system into the heart of most of our major cities. $^{213}$

Should these arguments fail to persuade, the rail transit proponent can fall back on the two-pronged subsidy argument. The initial argument is that society has long subsidized the automobile user, especially in the Interstate Highway Program, and that equity now requires that mass transportation be subsidized. ${ }^{214}$ Whether this argument is logically valid or not, its factual premises are incorrect. Highways are almost universally financed by user charges in the form of license fees, gasoline taxes, and so forth. Most of those who have studied the matter have concluded that the urban highway user generates revenues that are at least sufficient to cover the costs of construction and maintenance of the roads he uses. ${ }^{215}$ The situation with regard to local street costs provides more support for the subsidy argument; but local streets are necessary to provide abutting property with essential fire, police, and sanitation services, so it can be argued that the cost should be at least partially if not totally

$\widetilde{210}$ Text accompanying notes 88-127 supra.

${ }^{211}$ See text accompanying note 121 supra.

212 See Motor Vehicle Manufacturers Association, 1972 Automobile Facts and Figures 54; OECD, supra note 126, at 17; TrafFic in Towns, supra note 84, at 14-16; see also Abelson, Quantification of Road User Costs, 7 J. Transp. ECON. \& Policy 80, 93 (1973).

${ }^{213}$ See note 121 supra \& accompanying text.

For the theory applied to rail rapid transit, see E. Roszner $e t$ al., The Impact of Rapid Transit, July, 1971, summarized in ABstracrs, supra note 194, at 396; C. Russell, The Changing Environment of the Transit Industry (Harvard Business School 1969); Dajani \& Egan, Income Distribution Effects of the Atlanta Transit System, in Transportation FOR THE POOR, supra note 8 , at 35 . Fifty percent of the net operating benefits of London's Victoria Line "were attributed to reductions in congestion costs." J. Thomson, supra note 76 , at 85 (citing Foster \& Beesley).

${ }^{214}$ See, e.g., statement of Senator Percy, Hearings on Emergency Mass Transit Legislation Before the Subcomm. On Housing and Urban Affairs of the Senate Comm. on Banking, Housing and Urban Affairs, 91st Cong., 2d Sess. 21 (1972): "For years Congress has pumped billions of dollars into highway construction while starving our mass transit systems."

${ }^{215}$ See MEYER, supra note 3, at 62, 68. The exceptions are urban highway users who "as a whole have been paying more than the costs of the facilities they use . . ." Id. But see L. FITCH, supra note 84, at 266 (Table IV-3) (indicating incremental highway costs represent substantial subsidy to peak hour auto commuter). 
borne by the benefited property. ${ }^{216}$ Moreover, it appears that "urban vehicles as a group actually may pay more in user taxes than all urban highway costs, including those for local streets."217

The subsidy argument acquires some validity with regard to peak hour use of urban freeway and arterial facilities. ${ }^{218}$ One of the principal difficulties in analyzing this issue is in determining a definition of highway design capacity, because the analysis turns on a distinction between the capacity required for off-peak and the capacity required for peak demand. Under either of the two most plausible definitions of congestion, ${ }^{219}$ it appears that there is a subsidy element with regard to "very-high-cost urban expressways." But because the journey to work generally involves use of these highways and "over-priced" portions of the system (local streets), the subsidy element is probably de minimis.

The second part of the subsidy argument states that urban mass transportation should be viewed as a public service, like police and fire protection. ${ }^{20}$ The reasoning behind this position is not altogether clear, although much of the argument revolves around the "transportation disadvantaged." In fact, however, recent developments in the extension or construction of rapid transit systems seem designed primarily to serve middle or upper middle class commuters, not the transportation disadvantaged. ${ }^{221}$ To the extent that such projects represent a

${ }^{216}$ See MEYER, supra note 3, at 68.

217 Id. 69.

${ }^{218}$ See L. Fitch, supra note 84, at 265 (Table IV-2) (marginal social cost of peak hour use of urban freeway has been estimated to exceed $11 f$ per vehicle-mile versus $1 f$ per vehicle-mile paid in gasoline taxes); Walters, The Theory and Measurement of Private and Social Cost of Highway Congestion, 29 Econometrica 676, 677, 693 (1961) (taxes on urban roads should be increased by $4-8 c$ a mile during off-peak periods and $10-15 t$ a mile during peak periods if marginal private cost is to be equated with marginal social cost).

219 See MEYER, supra note 3, at 69.

${ }^{220}$ See, e.g., N.Y. Times, Dec. 29, 1974, § 4, at 4, col. 4; Workshop No. 11, Conference on Transportation and Human Needs in the 70's (Am. U.), June 19, 1972, at 140 ("The group concluded that it was a shiboleth that a transit system should be selfsupporting, and that transportation services must be subsidized by government in the same manner as water and sewage."); Cooper, Prospects for a Mass Movement to Public Transit, 5 URBAN LAw. 679, 693-702 (1973) (summarizing and criticizing proposals); U.S. News \& WORLD RePort, Mar. 13, 1972, at 75 ("People have to start thinking of transit as a public service-like the fire or police department-instead of a profit-making business.") (quoting Carlos Villarreal, UMTA Administrator).

A related argument is that the benefits of mass transit reach a public larger than its users and the users should not be forced to bear the entire financial burden. See Batchelder, Land Use Transportation Controls for Air Quality, 6 URBAN LAw. 235, 274 n.166 (1974).

221 The newly created BART will move suburbanites into the CBD. Transcript, 1st Sess., supra note 35, at 42 (remarks of Floyd). The same is true of the Washington, D.C., rapid transit system now under construction. It is estimated that it will carry $57 \%$ of the residents of Montgomery County who commute to jobs in Washington but only $21 \%$ of 
subsidization of the middle class they are regressive in their income redistribution effects and the poor would be better off if such expenditures were reduced. ${ }^{222}$

The relationship between the "transportation disadvantaged" and rail rapid transit is one of the ironies of the federal program. In establishing its funding priorities UMTA noted that urban areas with populations of under 250,000 are not ordinarly faced with automobile-related problems; nor are they likely candidates for mass transit technologies. ${ }^{223}$ The urban transportation problem in urban areas under 250,000 is, therefore, the problem of the transportation disadvantaged. In urban areas of one million or more, where the primary objective is the diversion of the automobile commuter, the goal of improving the lot of the transportation disadvantaged became "an objective to be met through the accomplishment" of the primary objective. When it became apparent that the solution adopted for solving the auto commuting problem-rail rapid transit-was in fact working counter to the interests of the transportation disadvantaged, the Act was amended in 1970 to recognize "the national policy that elderly and handicapped persons have the same right as other persons to utilize mass transportation facilities and services."224 This policy accounts for the rather strange definition of "handicapped" discussed earlier-that to be transportation handicapped is to be handicapped in the use of existing mass transportation. ${ }^{225}$

the Washington residents employed in Montgomery County. See S. Myers, supra note 57, at 5 .

The rapid transit line that runs from Skokie, Illinois, to downtown Chicago "serves a ridership consisting of households 86 percent of which own a car and 33 percent of which own two cars." R. Buel, supra note 101, at 150. During the first two years of service, costs (including interest) exceeded revenues by $\$ 485,000$, or $14 f$ per trip. $M$. Wohl, supra note 10, at 19. At that time (1967), the median family income for Skokie passengers was $\$ 12,900$, compared with $\$ 7,342$ (1960 census) for the Chicago SMSA. Id. 21 .

The UMTA-funded 1971 extension of Boston's rapid transit system provided service for passengers whose mean income level was $\$ 14,000$. See Metropolitan Area Planning Council, supra note 185, at V-48.

${ }^{222}$ Transcript, 2d Sess., supra note 36, at 54 (remarks of Kain); see also R. Burco, Urban Public Transport: Service Innovations in Operations, Planning and TECHNOLOGY 1-5 (1972). For a summary of the arguments for subsidies, see Frankena, Income Distribution Effects of Urban Transit Subsidies, $7 \mathrm{~J}$. Transp. Econ. \& Policy 215 (1973). Professor Frankena concluded that in Canada "the evidence does not support the popular impression that in general subsidization of urban public transit contributes to the well-being of low-income groups." Id. 227.

${ }^{223}$ MANUAL, supra note 6, at IIB-17.

${ }^{224}$ Urban Mass Transportation Assistance Act of 1970, 49 U.S.C. $\S 1612(a)$ (1970).

${ }^{225}$ See text accompanying notes 27 \& 32 supra. 
This criticism does not deny that the handicapped are transportation disadvantaged; the handicapped encounter grave difficulties in attempting to use public transportation. ${ }^{226} \mathrm{~A}$ systematic cataloging of these difficulties would indicate the kinds of changes needed to make public transportation more accessible to the handicapped. Fare collection points ought to be dispersed so that fares are collected while waiting for a vehicle, during the trip, or afterward. Turnstiles should be replaced with gates and shelters provided at bus stops. Rushing for trains and buses, which occasions many of the fears of the handicapped in their use of transit, could be reduced if accurate arrival and departure schedules were available. Because handicaps affect passengers throughout their trip, the entire system needs to be modified if the handicapped rider is to benefit. One who cannot walk long distances (about sixteen percent of the handicapped) cannot usually climb stairs, wait in line, or move rapidly. To remove the principal physical barriers to the use of mass transit facilities by the handicapped would involve capital expenditures of nearly one billion dollars. ${ }^{227}$

Who would benefit from this expenditure? In our earlier discussion we noted that thirty-eight percent of the handicapped, approximately five million persons, live in "transitoriented" urban areas. Even if an area is transit-oriented, however, an individual desiring to ride may not have transit available. (Availability is generally understood to be the loca-

${ }^{226}$ In a survey of elderly passengers on the New York City subway system, $54 \%$ of those interviewed agreed with the statement that "it is dangerous to ride the subway because the doors close too fast." Nahemow, Shuman \& Kogan, Findings From a Study of Participants in a Reduced Fare Program, in Transportation and AgIng, supra note 13, at 42,47 . In a San Antonio survey the most common complaint was infrequency of service, which resulted in long periods of standing at bus stops. See Carp, Public Transit and Retired People, in id. 82, 85. See generally TRAVEL Barriers, supra note 27, at 41.

${ }_{227}$ The total cost of $\$ 990$ million is made up of (1) $\$ 5000$ per bus for 50,000 existing buses, (2) $\$ .8$ million per existing transit stop for 800 stops, (3) $\$ .5$ million per stop in new systems for 200 stops. UMTA, supra note 12, at 16 . These estimates may even be far too low. William Ronan, Chairman of the Metropolitan Transit Authority in New York, projected a minimum capital cost of a billion dollars to equip the subway system with elevators at every station. See Ronan, Transit System Planning and Management for Transit Dependent Groups, Conference on Transportation and Human Needs in the 70's (Am. U.), June 20,1972, at 158, 164. BART stations are equipped with self-service elevators from street to train platform. Restrooms have been designed to accommodate wheelchairs. Stairs at stations have handrails that extend 18 inches beyond the top and bottom steps. Wilson, The Elderly and Handicapped on The San Francisco Bay Area Rapid Transit System, in Transportation and Aging, supra note 13, at 159, 161. The FederalAid Highway Act of 1973 requires that transit vehicles financed under its provisions be equipped for effective utilization by the elderly and the handicapped. 23 U.S.C. $\S 142$ (Supp. III, 1973). 
tion of a transit stop within two blocks of the point of origin or destination.) Of the five million handicapped in transit-oriented areas, 700,000 live within two blocks of a transit stop but cannot use transit because of their handicap. ${ }^{228}$

The relevant issue with regard to the handicapped and the transportation disadvantaged in general is therefore not how mass transit can be modified to meet their needs but rather what their transportation needs are. Our analysis of the latter point led us to conclude that they need public transit, not mass transit, and that adequate public transit may be expeditiously provided by modification of the existing system of taxicabs. Despite the admonition of section 3(e) of the Act that assistance should not be given to public transit bodies that compete with private transit companies, a recently published study indicates that reduction in the number of taxicab businesses and employees may be correlated with UMTA grants. ${ }^{229}$ The existing federal program seems therefore to operate against, rather than in favor of, the transportation disadvantaged.

The available data seem to buttress the conclusion that devoting billions of dollars to the improvement of rail rapid transit is unlikely to lead to a significant diversion of work trips from automobile to mass transportation. ${ }^{230}$ The issue is not how rail rapid transit can be used to divert automobile commuters but how automobile commuters can be persuaded to leave their cars at home. This requires an exploration of why commuters drive to work. The crucial question is why, given a choice between the automobile and public transportation, the commuter invariably chooses the automobile. It is submitted that this problem cannot be solved simply by examining and attempting to cure the afflictions of mass transit, because those afflictions are the result, not the cause, of increased automobile commuting. As early as 1918 mass transit began to reflect the characteristics of a dying industry. ${ }^{231}$ The decline in total revenue passengers on all forms

${ }^{228}$ Text accompanying note 29 supra; UMTA, supra note 12 , at 16.

${ }^{229}$ See Black, The Impact of Transit Subsidy on the Taxi Industry, 28 TRAFFic Q. 619, 628 (1974). Section 3(e) is a weak shield for the affected private competitor because he has no standing to challenge a grant and even if he did, the Secretary's determinations would probably stand, see South Suburban Safeway Lines, Inc. v. City of Chicago, 416 F.2d 535, 539-40 (7th Cir. 1969).

${ }^{230}$ See generally text accompanying notes 200-205 supra.

${ }^{231}$ Eckert \& Hilton, The Jitneys, 15 J.L. \& ECon. 293 (1972). See also Heathington \& Scott, Public Transportation in Urban Areas 3,4 (Transp. Research Bd. Special Rep. No. 144, 1974). Six years after it embarked on its massive aid program, Congress finally 
of public transportation from 18.98 billion in 1945 to 5.27 billion in 1972 correlates almost perfectly with the rise in automobile ownership. ${ }^{232}$ Before an intelligent program can be fashioned to remedy and to prevent the damage inflicted upon our cities by automobile commuting, one must understand why commuters drive.

\section{Why Commuters Drive}

The most thorough study on why individuals prefer automobiles to public transit was published in 1969 by Paine, Nash, Hille, and Brunner. ${ }^{233}$ In surveys of consumer attitudes conducted in Baltimore and Philadelphia, the authors found that respondents considered the following factors important determinants of mode choice for work trips: First place was given to what the authors term "reliability of destination achievement," which incorporates a stated preference for safe arrival. ${ }^{234}$ Private auto travel was considered as safe as public transit despite statistical evidence to the contrary. ${ }^{235}$ The faulty perception is most likely explained by the degree of control exercised over the

recognized that the sad state of mass transit was an effect of increased access to automobiles. See, e.g., H.R. REP. No. 1264, supra note 143, at 3.

232

$\begin{array}{ccc}\text { Year } & \begin{array}{c}\text { Auto } \\ \text { Registrations }\end{array} & \begin{array}{c}\text { Transit Revenue } \\ \text { Passengers } \\ \text { (millions) }\end{array} \\ 1945 & 25,694,926 & 18,981.9 \\ 1950 & 40,190,632 & 13,845.0 \\ 1955 & 51,960,532 & 9,189.0 \\ 1960 & 61,430,862 & 7,521.0 \\ 1965 & 74,903,163 & 6,798.0 \\ 1970 & 88,762,304 & 5,931.7\end{array}$

Sources: Motor Vehicle Manufacturers' Association, 1973-74 Automobile Facts AND Figures 16; '72-'73 TRANSIT FACT Book 8 (Table 6). The negative correlation between automobile ownership and the use of public transit is a widespread phenomenon. In Gothenberg, Sweden, for example, the ratio of population to private cars decreased dramatically from 40 in 1950 to 18 in 1955 , to 7 in 1960 , to 4.6 in 1965 , and thence to 3.6 in 1970. At the same time, the drop in the ratio of public transit journeys to population went from a highpoint of 334 in 1950 to 296 in 1955, 239 in 1960, 219 in 1965, and 192 in 1970. See HUD BRIEF, supra note 80 , at 24. Similar correlations are reported for London and Madrid in U.S. DEP'T of TransPortation, supra note 201, at 31, 40.

${ }^{233}$ Paine, et al., Consumer Attitudes Toward Auto Versus Public Transport Alternatives, 53 J. Applied Psychology 472 (1969) [hereinafter cited as Paine]. See also Quarmby, Choice of Travel Mode for the Journey to Work, 1 J. TransP. ECon. \& Policy 273 (1967).

${ }^{234}$ Paine, supra note 233, incorporates a preference for "on-time" arrival, a factor given pride of place in other surveys, e.g., Golob, supra note 26 , at 91 , into the second category, travel time, see text accompanying notes 246-47 infra.

${ }_{235}$ See Passenger Psychological Dynamics, supra note 108, at 6. But of. Boston Globe, Aug. 2, 1974, at 39, col. 1. 
transit mode. ${ }^{236}$ The safety of transit passengers is in the hands of third parties, while a substantial portion of the risk of accidents in automobile travel is a function of the driver's skill and the condition of his vehicle. Although buses or subway trains may be considered safer on the average, the perceived risk in any one case from the passenger's point of view may be magnified by the unknown condition of the vehicle and skill of the driver. In such circumstances it may be "safer" to rely on one's own abilities. Moreover, if one considers oneself a "good driver," the universal accident statistics can be implicitly dismissed as irrelevant. Finally, even if one knows that transit vehicles are "safer," the absolute incidence of accidents and fatalities in cars for any one individual is so small as to be discounted as de minimis. ${ }^{237}$ Thus in a category in which transit enjoys an advantage, namely safety, that advantage is lost because of the "faulty" perception of the commuter.

Paine found that the second most important consideration in work trip modal choice was travel time. ${ }^{238}$ Consumers perceived a significant difference between the alternative transit systems, with ninety percent satisfied with automobile travel time but only sixty to seventy percent satisfied with public transit travel time. ${ }^{239}$ Although rated second in overall importance, travel time is in fact the key determinant of modal choice. ${ }^{240}$ This finding-confirmed by recent studies in Boston, Chicago, San Francisco, and Leeds, U.K., ${ }^{241}$ as well as in several German cities ${ }^{242}$-bodes ill for mass transit in its efforts to lure automobile commuters. Because mass transit cannot provide doorto-door service and almost always involves waiting and changes of vehicle, it will rarely if ever be able to achieve a time advantage over the automobile.

Even if technology could afford mass transit such an advantage, the advantage might not weigh heavily with commuters

\footnotetext{
${ }^{236}$ See Baum, supra note 209, at 11 .

${ }^{237}$ See Passenger Psychological Dynamics, supra note 108, at 7.

${ }^{238}$ Paine, supra note 233 , at 476.

${ }^{239}$ Id. 474.

${ }^{240}$ See Wallin \& Wright, Factors Which Influence Model Choice, 28 Traffic Q. 271, 276 (1974); Bailey \& Dimitriou, supra note 194, at 565; Passenger Psychological Dynamics, supra note 108, at 14. See also McDonough, The Demand for Commuter Rail Transport, $7 \mathrm{~J}$. Transp. Econ. \& Policy 134, 142 (1973); G. Kraft \& T. Domencich, supra note 93, at 11

${ }^{241}$ See McGillivray, supra note 23 , at 847 (in cost-time model, time always the "stronger" variable).

${ }^{242}$ See Baum, supra note 209, at 11.
} (Table 2). 
because of "qualitative" differences in time. Transit planners generally assume that commuters perceive "out-of-vehicle" time as longer in duration than "in-motion" time. The latest figures indicate that time spent waiting and interchanging vehicles is valued at two to three times time spent in the vehicle. ${ }^{243}$

Next in importance in the Paine study was the "weather factor," which was divided into two points: "vehicle unaffected by weather" and "protected from weather while waiting." On the latter point, as might be expected, the automobile enjoyed an overwhelming preference. Transit planners have generally assumed that the advantage is lost in a "trade-off" against the relative imperviousness of public transit to weather conditions; but consumers in fact also gave the automobile a higher rating on the "vehicle unaffected by weather" criterion. ${ }^{244}$

Cost appeared as a surprisingly low fourth on the list of importance in modal choices. ${ }^{245}$ More surprisingly, consumers saw auto travel for work trips as significantly less expensive than public transit. ${ }^{246}$ This perception can probably be explained by the average consumer's failure to take depreciation into account as a cost. In a government study of the costs of owning and operating an automobile, depreciation was the single greatest cost. ${ }^{247}$

${ }^{243}$ Quarmby, supra note 233, at 280, 292; PAssenger Psycholgocial Dynamics, supra note 108, at 21; Transcript, 3d Sess., supra note 45 , at 5 (remarks of Domencich); Navin, Urban Transit Ridership in an Energy Supply Shortage, 8 TranSP. REsearch 317, 318 (1974). See also Vickrey, Pricing, Metering, and Efficiently Using Urban Transportation Facilities, in PRICE-SUBsidy Issues, supra note 62, at 36. There are no studies indicating what increments of time are significant.

244 Paine, supra note 233, at 477.

${ }^{245} \mathrm{Id}$. Another study indicated that, of the 28 factors found to affect modal choice, cost ranked nineteenth. Lisco, Value of Commuters' Travel Time: A Study in Urban Transportation, in Economic Factors Influencing Engineering Decisions 36 (Highway Research Record No. 245, 1968). In fact, survey data indicate that $72 \%$ of auto commuters "never bother to estimate what it costs to drive to work." See Lansing \& Hendricks, How People Perceive the Cost of the Journey to Work, in Passenger Transportation 44, 45 (Highway Research Record No. 197, 1967). But see Inglis, A Multimodal Logit Model of Modal Split for a Short Access Trip, in Travel Behavior 12 (Highway Research Record No. 446,1973 ) (commuters equate significance of travel cost and travel time).

${ }^{246}$ Paine, supra note 233 at 477. But see Lansing \& Hendricks, supra note 245, at 55: "Because people in general overestimate the cost of gas and oil for driving to work, it is not surprising that they tend to think of the automobile as the more expensive mode of travel."

The reason one may well be shocked is that recent studies by the Federal Highway Administration indicate that the average cost per mile for operating an automobile was 13.6x for a standard sized vehicle, $10.8 x$ for a compact, and 9.4 $x$ for a subcompact. These costs do not include parking fees. No public transit system charges a fare even close to these figures for an average work trip.

${ }^{247}$ U.S. Dep't of Transportation, Cost of Operating an Automobile 5 (1972) [hereinafter cited as Cost of Operating an AutomobiLe]. There is some evidence that rates of depreciation are accelerating. See R. BuEL, supra note 101, at 24-25. 
The urban transit consumer normally dismisses this cost out-of-hand, ${ }^{248}$ on the theory that because he needs his automobile for personal use, the only relevant costs of his work trip are the variable costs directly attributable to the trip, such as gasoline, tolls, and parking. ${ }^{249}$ These do not usually total more than $25 \%$ of total trip costs of a reasonably new car. ${ }^{250}$ The relative insensitivity of drivers to the cost differences between mass transit and automobiles has been established in several studies. ${ }^{251}$

${ }^{248}$ Survey data indicate that only one third of respondents include depreciation in their cost estimates of the journey to work. Lansing \& Hendricks, supra note 245 , at 47. See also L. Frrch, supra note 84, at 128.

${ }^{249}$ See Paine, supra note 233, at 477; Lansing \& Hendricks, supra note 245 , at 48 . The latter indicate that this is "appropriate" because, inter alia, "the journey to work accounts for only a quarter to a third of the annual mileage on cars." Id. 49.

${ }^{250}$ L. Fiтch, supra note 84, at 128; see also Segelhorst \& Kirkus, Parking Bias in Transit Choice, 7 J. Transp. Econ. \& Poucy 58, 59 (1973). The FHWA figures indicate the variable cost component of the total cost per mile of a standard size vehicle at $28 \%$, of a compact vehicle at $33 \%$, and of a subcompact at $34 \%$. See Cost of Operating an Automobile, supra note 247 , at 5 .

For data and analysis indicating that gasoline prices have little effect on comsumption, see Hooper \& Mullen, The Effect of Increased Fuel Prices on Car Travel, 15 TRAFric ENG'R \& Control 728 (1974); Orski, supra note 94, at 249. For data and analysis indicating that the relationship between gasoline prices and consumption is unity, see $\mathrm{J}$. Thomson, supra note 76, at 91-92. What the data do not reveal, however, is the effect of gasoline price increases on work trips.

Parking fees are almost equal to vehicle operating costs but are involved in only $8 \%$ of automobile journeys to work in metropolitan areas. Lansing \& Hendricks, supra note 245 , at 49 .

${ }^{251}$ One leading study analyzes "the kinds of price changes that would be required to induce shifts from automobile commuting to public transportation . ..." Moses \& Williamson, Value of Time, Choice of Mode and the Subsidy Issue in Urban Transportation, $71 \mathrm{~J}$. Pol. Economy 247, 259 (1963). Based upon interviews of commuters from the Chicago area conducted by the Cook County Highway Department, the authors constructed a table of diversion prices. Ignoring disutilities, the authors found that an increase in the cost of automobile commuting of ten cents per trip would divert $7 \%$ of the auto commuters who had the alternative of commuting by mass transit. Thereafter they plotted the following diversion prices: up twenty cents, $14 \%$; thirty cents, $23 \%$; forty cents, $33 \%$; fifty cents, $43 \%$; sixty cents, $54 \%$. Id. 260 (Table 1 ). That there is a price at which even the most tenacious driver will be diverted will be considered at note 282 infra. Moses and Williamson also calculated the diversion effects of reducing transit fares. These figures are more surprising. If a transit fare of thirty cents were reduced to zero it would divert $13 \%$ of those for whom the bus and streetcar are alternatives and $18 \%$ of those for whom the el-subway is the alternative. More substantial diversions would require negative prices. Id. 261 (Table 2). The authors caution that the figures may overestimate potential diversion because they do not take into account disutilities and assume one passenger per automobile. Id. 262.

Other studies have indicated a general price elasticity for transit of -.20 . Price elasticities ranged from a low of -.08 in Baltimore to a high of -.30 in Chicago. See Charles River Associates, Inc., An Evaluation of Free Transit Service, 1968, quoted in J. Thomson, supra note 76, at 98 .

Similar price elasticities are found in Europe. In a study of eight German cities, price elasticities ranged from a low of -0.015 in Hanover to -0.41 in Hamburg. See Baum, 
Finally, the Paine study identified a number of items as "disutilities" of mass transit, which are difficult, if not impossible, to quantify. ${ }^{252}$ Because there is no data indicating the extent to which these disutilities outweigh any cost or time advantages enjoyed by mass transit, they are the great unknowns of the urban transportation problem. The condition of the vehicle and its effect on the riders' comfort is one of the most important disutilities. ${ }^{253}$

Paine also identified a stated consumer preference for avoiding "riding with strangers" and "unfamiliar areas." The desire to avoid "riding with strangers" may be a particularly formidable barrier for mass transit to overcome. The desire to live in a "nice" neighborhood and to send one's children to schools with other "nice" children are commonplace phenomena; the same prejudices inform choices of transportation mode. The desire to isolate oneself from a cross-section of the community is thus not a surprising component of individuals' aversion to public transit. The aversion to riding with strangers may also flow in part from occasional, but sensational, reports of criminal activity on public transit vehicles. ${ }^{254}$ Another

supra note 209, at 4. See also Srudy, supra note 175 at V-5 (Rome's no-fare experiment failed to decrease auto traffic after forty-three days). These elasticity figures are for all types of trips. Both the German and the American data, however, indicate that the cross elasticities are lower for work trips. See Baum, supra, at 5 .

An econometric model of urban travel demand developed by Charles River Associates, Inc., indicates a cross-elasticity between auto work trips and transit with regard to cost of only .138 for the line-haul portion of a transit trip and a zero cross-elasticity for the access portion, e.g., feeder bus. G. Kraft \& T. Domencich, supra note 85, at 18. Experiments in Philadelphia and Boston in 1962 and 1963 indicated that "under the most modern of assumptions" it would cost at least $80 c$ per round trip or $\$ 200$ per year to divert a commuter from auto to transit. MEYER, supra note 3, at 101-02. See also Kain, $A$ Contribution to the Urban Transportation Debate: An Econometric Model of Urban Residential and Travel Behavior, 46 Rev. Econ. \& STAT. 55 (1964) (insensitivity of transit ridership to increases in service frequency). But of. Segelhorst \& Kirkus, supra note 250 at 61 (service level elasticities seven to ten times greater than fare elasticities).

252 Paine, supra note 233, at 478. See also McGillivray, supra note 23, at 834 (e.g., weather, need for freight or passenger carrying capacity, comfort, flexibility, time of day); Quarmby, supra note 233, at 281 (comfort, safety, reliability); Costantino, Attributes of Transit Demand, 29 TRAFFIC Q. 243, 257 (1975).

${ }^{253}$ See DeSimone, Issues of Urban Transportation and the Environment, in URBAN Transportation NeEds 18, 20 (1972).

${ }^{254}$ In the New York City subways, for example, transit police indicated that from January 1, 1973 to August 15, 1973 there were 831 robberies of passengers, 198 felonious assaults, and 952 purse snatchings reported. For 1972 the figures were 1315 passenger robberies, 304 felonious assaults, and 1163 purse snatchings. N.Y. Times, Aug. 18, 1973, at 1, col. 2, 53, col. 1. See Nahemow, Shuman \& Kogan, supra note 226, at 42, 47. The failure of carpooling has been attributed to the loss of privacy inherent in the system, see Eash, Swanson \& Kaplan, An Analysis and Evaluation of Alternate Schemes To Increase Auto Occupancy, 8 Transp. ReSEARCH 335, 341 (1974). 
important disutility, and perhaps a corollary of the "avoiding riding with strangers" factor, is the need for privacy, in which case an absolute time or cost advantage for mass transit would be irrelevant.

Faulty perceptions and irrationality so pervade the question of consumer choice of urban transport mode that one must ask if modal choice is determined by factors operating beyond the conscious level. That there is a strong subconscious tie to the automobile has long been an element of popular mythology, but there is little published data supporting the nexus between the automobile and subconscious desires.

Means by which mass transit can be "reinvigorated"255 so as to cope with the modal choice variables considered in this section are difficult to imagine. A public relations campaign might impress upon commuters the greater relative safety of mass transit. The costs of mass transit trips might be better equated with the costs of automobile commuting by adoption of a multi-trip ticket. ${ }^{256}$ The aversion to riding with "strangers" might be overcome by creating several classes of service as in the Paris Metro. ${ }^{257}$ The federal program seems well designed to deal with the problem of vehicle condition and will undoubtedly succeed in providing many existing systems with shiny, new equipment, at least in the short run. Federal programs that take account of the more significant determinants of modal choice remain to be unveiled, and they may never come into existence.

Most observers agree that "it is unbelievably difficult to divert auto commuters to transit." 258 Note, however, that the "unbelievably difficult" task is to lure commuters to transit. The difficulties may not be as great if attraction is abandoned for a strategy of strong persuasion and mild coercion. Given the tenacity with which the auto commuter grips his steering wheel, the effort may have to involve substantial limitations on the freedom to use automobiles in urban areas. ${ }^{259}$

${ }^{255}$ Note 128 supra \& accompanying text.

${ }^{256}$ See R. Burco, supra note 222, at V-9; Christian Science Monitor, Apr. 27, 1972, at 7 , col. 1 .

${ }^{257}$ See Burck, How to Unchoke Our Cities, 63 Fortune, May, 1961, at 119, 264.

${ }^{258}$ Wall St. J., Oct. 11, 1973, at 22, col. 3.

${ }^{259}$ But cf. J. RAE, supra note 74, at 89: "One solution is compulsion; urban travel by private automobile could be prohibited or at least drastically restricted. This, however, is not only a counsel of desperation, whose adoption in a free society would be an acknowledgment of defeat, it is also a remedy likely to create more problems than it solves." 


\section{Limiting Automobile Commuting}

Programs to limit automobile commuting have been categorized as either traffic restraint or traffic restriction. A traffic restraint program would include all methods designed to dissuade people from using their cars. ${ }^{260}$ They range from a freeze on the approval of off-street parking facilities and the cessation of construction of new limited access highways in urban areas to the more positive steps of parking bans and toll systems. The most common and effective form of traffic restraint is congestion. This is, in fact, the principal reason why traffic will never "grind to a halt." 261 Vehicular traffic is self-regulating: congestion discourages traffic increments. The failure to recognize this fact-that to do nothing in the face of increasing congestion is a very effective means of traffic restraint-has led to massive incursions of limited access highways into central business districts and to the absurd arguments concerning the "need" for additional roads to "accommodate" future traffic demands.

The difficulty with relying upon congestion as the primary means of regulating automobile flow is that it is unplanned. ${ }^{262}$ Traffic restraint and traffic restriction strategies are examples of planned congestion. The difference between the two is that while traffic restraint strategies seek to discourage automobile commuting to and from the central business district, traffic restriction programs encompass methods of preventing vehicles from going where they would otherwise go by act of law and/or physical obstruction. Several traffic restraint and restriction programs will be discussed briefly. It must be borne in mind in considering such proposals that an important determinant of their viability, perhaps the determinant, is their political acceptability. ${ }^{263}$ Although it is impossible to articulate criteria for political acceptability in all situations, political tolerableness will

${ }^{260}$ See J. Thomson, supra note 76 , at 9.

${ }^{261}$ Id. 30-31. See Quarmby, supra note 233, at 273.

${ }^{262}$ See generally Kain, supra note 251, at 345; Patrassi, Balancing Road and Transit Systems, 23 Trafric Q. 441 (1969).

${ }^{263}$ The point was graphically illustrated in hearings on an EPA proposal to ration gasoline in order to limit auto travel and thereby lower air pollution levels in Los Angeles. In a statement before the hearing panel, Senator Tunney termed gasoline rationing "a drastic and nonsensical" measure that "would lead to economic and social chaos and be impossible to enforce without putting a bayonet at the back of every motorist. Instead of turning to police state solutions, we should mobilize our effort to develop mass transit and to mass produce an alternative to the internal combustion engine." N.Y. Times, Mar. 6, 1973, at 35, col. 3. One obvious difficulty with the EPA Los Angeles proposal was that it affected all motor vehicle operators as well as sellers of 
usually correlate in some measure with (a) the size of the group affected by the proposal, (b) the political vociferousness of the affected group, and (c) the group's ability to perceive that it has been affected. ${ }^{264}$

\section{A. Traffic Restraint}

The most widely considered traffic restraint program involves a system of toll charges to be levied against automobile commuters. ${ }^{265}$ The idea of toll charges is the subject matter of a voluminous literature whose primary concern is utilization of the price mechanism to rationalize highway investment and use. First, a price mechanism may be used to justify the commitment of resources to a particular use. ${ }^{266}$ (Advocates of mass transit argue that federal subsidization of highway construction has distorted the investment process.) ${ }^{\mathbf{2 6 7}}$ After allocating the cost of investment, the price mechanism can be useful in allocating how the facility should be used, as a form of rationing. ${ }^{268}$ This second phase of using tolls attempts to apply marginal cost pricing to highway use by relating tolls to the "congestion" costs imposed by the incremental vehicle. ${ }^{269}$ Despite the relative insensitivity of

gasoline instead of focusing more narrowly on those types of trips that cause a disproportionate amount of pollution, are easily postponed, or for which an alternate transport mode is available.

${ }^{264}$ A fuel tax cannot, for example, discriminate between urban and rural traffic, nor between times when urban roads are congested and when they are not. A 1964 Ministry of Transport study in England noted that "[a] charge of $1 d$ per mile is higher than the cost of using uncongested roads and far lower than the cost of using congested roads and thus discourages the use of lightly-trafficked roads and encourages the use of crowded roads ...." Great Britain Ministry of Transport, Road Pricing: The Economic and Technical Possibilities 9 (1964), quoted in J. Thomson, supra note 76, at 46 [hereinafter cited as Ministry of TRANSPORT].

${ }^{265}$ See L. FrTCH, supra note 84 , at 127 . Note that tolls cannot be levied on roads built with federal funding, see 23 U.S.C. $\$ 301$ (1970). Toll imposition on federally aided bridges and tunnels is restricted by $i d$. $\$ 129$ (a), as amended, (Supp. III, 1973). See also 33 U.S.C. $§ 529$ (1970).

${ }^{266}$ See Strotz, Principles of Urban Transportation Pricing, in Traffic Congestion as a Factor in RoAd-User Taxation 113 (Highway Research Record No. 47, 1964) [hereinafter cited as Traffic Congestion].

${ }^{267}$ See L. Firch, supra note 84, at 158, 265-66; text accompanying notes 214-18 supra.

${ }^{268}$ See Strotz, supra note 266, at 113.

${ }^{269}$ See Mohring, Relation Between Optimum Congestion Tolls and Present Highway User Charges, in Traffic Congestion, supra note 266, at 1 . In a study of traffic in London it was estimated that if traffic were moving at ten miles per hour, and another vehicle joined the stream, each vehicle-mile of the new vehicle would impose an additional eleven minutes to the travel time of all vehicles. This eleven-minute delay was estimated (in American currency) to be the equivalent of $52 \epsilon$ in the journey costs of all vehicles. G. Roth, PAYING FOR ROADS 29 (1967). Thus a rush hour entrant ought to pay 52c per mile as a congestion toll.

Two major criticisms are leveled against marginal cost/congestion pricing. It is ar- 
automobile commuters to price increases, ${ }^{270}$ tolls of sufficient magnitude would divert all but the wealthiest or most fanatical auto commuters. Even more modest tolls may serve as an effective restraint. ${ }^{271}$

A major difficulty with road toll proposals is in the mechanics of implementation. In cities like New York and San Francisco, where access is channeled through tunnels and bridges, reasonable toll points are readily apparent. Most other cities, however, are land-oriented and have scores of radial access routes. The nightmare of a toll booth on every street ${ }^{272}$ can be eliminated by automatic vehicle monitoring (AVM) systems. Such systems are primarily of two kinds, on-vehicle and off-vehicle. ${ }^{273}$ The trouble with the on-vehicle system is that meters may fail to function, either inadvertently or as a consequence of tampering. This problem may be avoided by using an

gued that the foundation of the marginal cost analysis is "the value of time" which is "so uncertain, so mercurial in character, that its use . . . is questionable." St. Clair, Congestion Tolls-An Engineer's Viewpoint, in TRAFFIC Congestion, supra note 266, at 66, 99. A second objection is the unfairness of making the traveler who suffers from congestion also pay for it. Id. 86.

${ }_{270}$ The econometric model of urban travel demand developed by Charles River Associates, Inc., indicated an elasticity of auto work trips to parking and toll charges of -.071. See G. Kraft \& T. Domencich, supra note 85, at 18. In this model elasticity is "the percentage change in the number of trips demanded for a given purpose and mode in response to a one percent change in one of the variables ...." Strangely the model indicates an elasticity of -.494 with regard to all auto operating costs. Id.

${ }^{271}$ Research among auto drivers in Stockholm indicates that congestion toll of $15 \%$ would deter $44 \%$ of those questioned from entering the central city by car and a $75 c$ toll would deter 63\%. Swedish Road Federation, The Automobile in Swedish Society (1971), quoted in W. OweN, supra note 3, at 51. See also Moses \& Williamson, supra note 251 , at 261 (Table 1) (at an added driving cost of $\$ 1.00$ per trip, $77 \%$ of auto commuters would be diverted to public transit modes.) For a detailed and sophisticated analysis relating congestion costs to road charges, see Strotz, Urban Transportation Parables, in THE Public Economy of Urban Communities 127 (J. Margolis ed. 1965).

${ }^{272}$ Note, however, that one of the risks of a toll system is diversion to other parts of the system. This requires wide coverage and "sophisticated differentiation between different classes of facilities." MEYER, supra note 3, at 65. Professor Samuel Abbott suggests that a limited number of toll points plus "congestion" on the free corridors may solve the problem.

${ }^{273}$ In an on-vehicle system, meters are installed in all vehicles, electrical loops are placed in the roadbed, and the meter begins to operate when the vehicle enters a delineated zone (continuous pricing system) or is advanced when the vehicle passes over electronic coils at different places (point pricing system). The coils can be altered to vary tolls depending on the traffic volume or other relevant factors (coil systems could even be used to replace parking meters); while meters could be varied to reflect performance, pollution, and noise characteristics of each vehicle.

AVM utilizing on-board transmitters are used to monitor bus traffic in Hamburg, and a combination of on-board and in-street equipment is being used experimentally in Rochester, N.Y., to increase bus traffic. See R. BuRco, supra note 222, at III-19, 20. Such systems would cost roughly two cents per trip. MEYER, supra note 3 , at 325 . 
off-vehicle system, in which the unit on the vehicle serves solely for identification purposes. As the vehicle passes over pricing points its identity is recorded and a monthly bill is presented to the registered owner. ${ }^{274}$

A mechanical problem presented by both AVM systems is installation of recording or identification meters in automobiles. At the end of 1971 there were eighty-three million automobiles registered in the United States. To provide for the installation of recording meters in all of them within a limited time period would be virtually impossible. To provide for phased-in installation on new cars only would take many years, and such a policy would place a heavy premium on ownership of a pre-metered automobile. While the installation of identification meters might be simpler and accomplished more expeditiously (for example, through attachment to license plates), ${ }^{275}$ their use raises a serious question of invasion of privacy.

Even if the mechanical difficulties could be overcome, ${ }^{\mathbf{2 7 6}}$ metering might not pose a sufficient deterrent to automobile use. Evidence suggests that the costs of automobile commuting can only be brought home to the commuter by periodic transactions on a daily basis. ${ }^{277}$ Monthly toll bills might begin to fade into the area of fixed costs not associated with any one trip. ${ }^{278}$ In England it has been suggested that tolls might be administered by renting or selling daily licenses which would permit the licensee to enter the central business district. These could be obtained from gasoline stations, roadside vending machines, or other generally accessible facilities. The price of a license could vary with the $\mathrm{CBD}$ destination point. This system would involve substantial reliance on individuals' cooperation with the requirement of purchasing a license. ${ }^{279}$

$274 \mathrm{~J}$. Thomson, supra note 76, at 53 . Equipment for an off-vehicle scheme has been under test in the United Kingdom for about three years. Results indicate that identification units could be mass-produced for about $\$ 12$ each and pricing points for about $\$ 5,000$ each. Id. 54 .

${ }^{275}$ G. Roth, supra note 269, at 47; see Sterzer, Electronic License Plate for Motor Vehicles, 35 RCA REv. 167 (1974).

${ }^{276}$ As of June, 1974, there were no "operational" metering systems in existence. See

R. KIRBY, supra note $\mathbf{5 9}$, at 411 .

${ }^{277} \mathrm{Cf}$. note 271 supra.

${ }^{278}$ See text accompanying notes $248-49$ supra.

${ }^{279}$ See J. Thomson, supra note 76 , at 47,49 ; Ministry of Transport, supra note 264 , at 15. This problem might be solved by the timer-ticket described in Myers, Collection Problems and the Promise of Self-Canceling Tickets, in Problems in Implementing Roadway Pricing 21 (Transp. Research Record No. 494, 1974).

A proposal to introduce a license for using a car in London was dropped for political 
The principal objections to all toll systems are political. First, they are regressive in impact. ${ }^{280}$ Second, and perhaps more significant, access to the existing system of roads and streets has been a "free" good for too long; without a major "repackaging" effort it is highly unlikely that automobile owners would tolerate the novel imposition of a toll system. ${ }^{281}$

To increase the palatability of a toll proposal, tolls might be applied to parking charges. ${ }^{282}$ Because the auto commuter is the all-day parker, a first step in discouraging him from driving to work would be to reverse the present practice of making it less expensive to park all day than to park for shorter periods of time. ${ }^{283}$ This could be done by adding a surcharge for arriving or leaving at peak hours. ${ }^{284}$ Such a system would be easier to administer than a metering system; but it would also be susceptible to evasion, primarily by collaboration between commuters and lot owners who prefer steady customers. Employer subsidies of parking fees ${ }^{285}$ and employer-supplied parking could also

reasons. See THE ECONOMIST, July 12, 1975, at 27 . An analogous EPA proposal for a "colored sticker" system was discarded because of public opposition. See Bracken, Transportation Controls Under the Clean Air Act: A Legal Analysis, 15 B.C. IND. \& CoM. L. Rev. 749,758 (1974).

${ }^{280}$ See Strotz, supra note 266 , at 114.

${ }^{281}$ See R. BuEL, supra note 101, at 73; (N.Y.C. mayor's proposal for $\$ 10$ annual use tax on automobiles killed "because of public pressure in favor of the automobile"); Fitch, Financing Urban Roadways, in Financing Highways 141 (E. Williams ed. 1957). See also G. RoTH, supra note 269, at 18: "Although the 'freedom of the road' is regarded by many as a traditional right, it is in fact a fairly modern idea; toll roads were ended in London only in 1871."

${ }^{282}$ But an EPA proposal for a $\$ 5$ parking surcharge for cars parked in CBD's between 6 a.m. and 10 a.m. was withdrawn due to "pressure from Congress." Boston Globe, July 21, 1974, at 2, col. 2. See generally South Terminal Corp. v. EPA, 504 F.2d 646,657 (1st Cir. 1974). Congress has prohibited the EPA from imposing parking surcharges, 42 U.S.C.A. § 1857c-5(c)(2)(B) (Supp. 1975). See 39 Fed. Reg. 1848 (1974).

Studies in London establish that drivers are not insensitive to increases in parking charges. As an experiment the London County Council doubled and quadrupled parking meter charges. The time necessary to find a vacant meter was reduced $60 \%$ when charges were doubled and $83 \%$ when they were quadrupled. Inwood, Some Effects of Increased Parking Meter Charges in London, Road Research Laboratory Rep. No. 7, 1965, quoted in Harvard Business School, Urban Road Pricing Through Selected Parking Taxes (Case No. 9-371-261), at 7.

A detailed case study is provided in Kulash, Parking Taxes as Rondway Prices: A Case Study of the San Francisco Experience (1974).

${ }^{283}$ See Kain, A Reappraisal of Metropolitan Transportation Planning, cited in Harvard Business School, supra note 282, at 13; L. FIrch, supra note 84, at 150.

${ }^{284}$ See J. Thomson, supra note 76, at 65-66; Meyer, supra note 4, at 65.

${ }^{285}$ See Environmental Directorate, supra note 101, at V-9. See also R. BURco, supra note 222, at V-7, V-10. A 1966 study indicated that between $30 \%$ and $50 \%$ of all CBD employees received subsidized parking. A national sampling indicated this figure may be as high as $80 \%$. See Segelhorst \& Kirkus, supra note 250 , at 58 . 
undermine the system. ${ }^{286}$

Limitation of space for parking is a form of traffic restraint that overcomes some of the shortcomings of tolls. ${ }^{287}$ Traditionally, permission to develop in urban areas has been tied to the developer's provision of parking facilities. Municipalities could reverse this practice by limiting the amount of space that developers could provide for parking. ${ }^{288}$ Space limitations are less susceptible to evasion or circumvention than tolls. Because commuters generally arrive downtown earlier in the day than shoppers or visitors, however, a limitation on parking spaces would discourage non-peak hour trips more than those by peak hour commuters. Prohibiting lots from opening before 10:30 a.m. would more effectively deter the commuter from driving. Even then, parking restrictions of any kind will only reduce that proportion of traffic that would have parked in the central business district, and "there is no definite relationship between parking space and traffic flow." 289 Moreover, the reduction in congestion by reducing "parking" traffic may only encourage an increase in "non-parking" traffic, such as trucks that move through the central business district on the way to the waterfront or other destinations. ${ }^{290}$

${ }^{286}$ See L. FITCH, supra note 84 , at 151 . KULASH, supra note 282 , at 5 , indicates that $20 \%$ of San Francisco's 50,000 off-street parking spaces are reserved for private employee parking. A survey of metropolitan areas in the mid-1960's indicated that "only 8 percent of auto journeys to work involve a parking fee." Lansing \& Hendricks, supra note 245 , at 49.

${ }^{287}$ See, e.g., J. Thomson, supra note 76, at 57; Fitch, Improving Urban Transportation, in The Future of American Transportation 179 (E. Williams, Jr. ed. 1971). Congress has also expressed some opposition to limitations on parking, but the EPA may impose such limitations after a public hearing. 42 U.S.C.A. $\S 1857 \mathrm{c}-5(\mathrm{c})(2)(\mathrm{C})$, (D) (Supp. 1975).

${ }^{288}$ In London, developers are now limited to maximum parking allowances. See J. Thомson, supra note 76, at 59. New York and Boston have limited new garage construction. In Chicago the same result is obtained indirectly by prohibiting driveways into streets with pedestrian flows exceeding 25,000 per day. See id. In Munich, developers can either provide parking in accordance with building ordinances or, if the city council requires it, contribute a sum of about ten percent less than prevailing construction costs for the required parking to finance parking lots at subway stops. Kühnemann \& Witherspoon, Thirty-Two German Cities, in Organisation For Economic Cooperation and Development, Streets For People 57, 65 (1974) [hereinafter cited as Streets For PEOPLE].

${ }^{289}$ G. Roth, supra note 269 , at 76. But see Governor Francis W. Sargent, Policy Statement on Transportation in the Boston Region, Nov. 30, 1972, at 6: "[I]t is essential that we employ the most effective lever available for the limitation of traffic demand -parking policy." On the difficulties of enforcing parking prohibitions, see Patrassi, supra note 262, at 459.

290 See Ministry of Transport, supra note 264, at 13. For a detailed comparison, see J. Thомson, supra note 76, at 97 . Empirical evidence indicates $15 \%$ to $30 \%$ of CBD automobile trips do not involve parking. See R. KIRBY, supra note 59, at 412. 
The flaw in traffic restraint programs is that they are incremental and in no way affect the way streets function in the core of the city. Incremental decreases in automobile commuting may be sufficient to reduce pollution or energy consumption to tolerable levels. But even if successful in reducing the system costs of automobile commuting, the victory may prove pyrrhic. Success in discouraging the auto commuter may result in his driving to a job in the suburbs instead of switching to inadequate public transit for the trip to the CBD. ${ }^{291}$ Such a change would not represent a departure from but rather an acceleration of an already existing trend. ${ }^{292}$

This perverse result points up the fundamental weakness of the federal mass transportation effort. It has been submitted that the federal attempt to "lure" commuters away from automobiles with new rail rapid transit systems will not solve the problem. Like the highway program and the systems of traffic restraint just discussed, it misses the fundamental point by viewing urban transportation as an end in itself with the goal of achieving the most "efficient" system of transportation. In contrast, the most basic transportation primers begin with a description of transportation as a system for getting from point $A$ to point $B .{ }^{293} \mathrm{~A}$ fortiori, if no one wants to get to point $B$ there is no need for a transportation system between points $A$ and $B$. Urban America has been witnessing an accelerating lack of desire to go from point $A$ (the suburbs) to point $B$ (the central business district). Two explanations for this phenomenon present themselves: first, the increased difficulty of going from $A$ to $B$, because of congestion, makes "getting there" not half the fun but no fun at all; second, point $B$ is becoming increasingly unattractive. The problem is not that " $[t]$ here is no there there," as Gertrude Stein once said of Oakland, California, but that whatever is there has become progressively less alluring to the increasing numbers of people who concentrate their lives in the suburbs. ${ }^{294}$

${ }^{291}$ See statement of Governor Francis W. Sargent, July 9, 1973 ("Drastic restriction on [automobile] travel to the core ... might well direct substantial economic activity from the core to the suburbs."); Moses, Economics of Consumer Choice in Urban Transportation, quoted in St. Clair, supra note 269, at 107-08.

292 Between 1960 and 1970 the number of people employed in the central city portion of metropolitan areas declined from $63 \%$ to $52.4 \%$. The percentage of those who live and work in the suburbs increased from $67.8 \%$ to $72.3 \%$. See N.Y. Times, Oct. 15 , 1972 , at 58 , col. 5 .

${ }^{293}$ Cf. Nahemow, Shuman \& Kogan, supra note 226, at 43; Webber \& Angel, The Social Context for Transportation Policy, 29 Ekistics 25 (1970).

294 McQuade, Dountown is Looking Up, ForTune, Feb., 1970, at 132. 


\section{B. Traffic Restriction}

A program to solve the urban transportation problem must contain two critical elements, one that will effectively discourage individuals from using automobiles for work trips into the center city and one that will encourage those individuals to continue to work in the city. A gradual introduction of a series of physical traffic restrictions will get individuals out of their cars without leading to a wholesale loss of jobs to the suburbs. A corresponding improvement in mass transit could effectively serve suburban commuters. Federal mass transit efforts alone may not be able to solve the urban transportation problem, but a refocusing of the effort combined with an effective system of traffic restrictions would get commuters out of their cars onto public transportation and would make the centers of cities more attractive for residents, workers, and visitors alike.

Jane Jacobs has suggested the concept for such a program and has labeled it "attrition":

Attrition as a steady, gradual process (something that does not now exist) would steadily decrease the number of persons using private automobiles in a city. If properly carried out .... attrition would decrease the need for cars simultaneously with decreasing convenience for cars. ...

In real life . . attrition of automobiles by cities is probably the only means by which absolute numbers of vehicles can be cut down. It is probably the only realistic means by which better public transportation can be stimulated ....

... Although its cumulative effects should be revolutionary, like any strategy aimed at keeping things working it has to be engaged in as a form of evolution. ${ }^{295}$

Such an attrition program can be implemented by traffic restriction, that is, by preventing vehicles from going where they would otherwise go by act of law and/or physical obstruction. The overall strategy is based on urban land use planning.

Urban land use planning must begin again with a recognition that the designation of an area as a "street" represents a first step, not an end, in the planning process. The second step involves acknowledgement that an urban street has more purpose 
than a route linking two points. With that insight, the planner can begin to choose from the wide array of possible street uses that most likely will be compatible with overall planning goals. Lewis Mumford has suggested that priority be given to use by pedestrians. "Nothing would do more to give life back to our blighted urban cores than to re-instate the pedestrian, in malls and pleasances designed to make circulation a delight." ${ }^{296}$

Barring vehicular traffic from a street or group of streets forces the planner to focus on a variety of street uses hitherto ignored. In many areas the street is the site of a daily promenade. ${ }^{297}$ Making provision for this type of activity amounts to a recognition that streets are "the main public places of a city."298 Pedestrian streets also provide a humanizing environment which tends to ameliorate the fear and alienation caused by being constantly surrounded by strangers. "The bedrock attribute of a successful city district is that a person must feel personally safe and secure on the street among all these strangers." 299 Fear is further alleviated by the cafe, an institution "almost always part of the street." 300 In fact, the cafe has been termed a stationary version of the promenade. On the Continent the cafe is considered indispensable to city life. ${ }^{301}$ Although some have attributed its absence in this country to American cultural characteristics, ${ }^{302}$ would the cafe not appeal precisely to that group of middle and upper middle class suburbanites who deplore the decay of the downtown area but in whose hands its revival lies? A committee appointed by the mayor of New York

${ }^{296}$ L. MUMford, supra note 124, at 244.

To encourage people to walk " $[\mathrm{t}]$ here must be short blocks so that there can be a varied pattern of street usage, so that intermingling of neighbors is encouraged, so that the opportunity for wide casual contacts is increased." R. BUEL, supra note 101, at 11 (paraphrasing Jane Jacobs).

${ }^{297}$ In several countries streets are in fact labeled by this function. Thus Spain has its rambla and paseo, Italy the corso, and France the cours, allée, and promenade. See $\mathrm{B}$. Rudofsky, Streets For People 112 (1969).

${ }^{298} \mathrm{~J}$. JAcoBs, supra note 80 , at 29.

299 Id. 30 . Jacobs believes the extremely high rate of street crime (e.g., forcible rape, aggravated assault) in Los Angeles is causally related to the "suburban" character of that city. See id. 32-33.

300 B. Rudofsky, supra note 297 , at 308 .

301 Id. 310.

${ }^{302}$ Id. 19. Rudofsky observes that the Americans adopted the English conception of street life, which precluded the use of the street for cafes, special interaction, recreation, or indeed anything but hurried passage. Samuel Johnson is said to have observed, "Almost anything that sets us above savages has come from the shores of the Mediterranean." Lord Tennyson may have expressed the predominant English view: "I loathe the squares and streets/ And the faces that one meets." Id. 19. 
City reported that "more sidewalk cafes and later closing hours would bring the people back into the streets, thereby reducing the likelihood of crime in the streets." Street crime would be deterred not only by the increased numbers of potential witnesses and "apprehenders" but also by a heightened sense of responsibility for the safety of others which comes from "sidewalk contacts." 303 Thus pedestrian use of streets for a variety of purposes should enjoy a high priority.

Second, CBD streets must be used for the delivery of freight in a way that allows necessary access while minimizing interference with pedestrian uses. One solution to the inefficiency of present-day delivery systems and their excessive number of truck trips into the $\mathrm{CBD}$ would be to establish one or more freight consolidation terminals on the periphery of the city or at its center. $^{304}$ Interference with other street uses could also be reduced by restricting permissible delivery times to early morning or night hours. ${ }^{305} \mathrm{~A}$ more imaginative proposal would utilize existing rapid transit lines and underground freight railways to

${ }^{303}$ B. RudofsKy, supra note 297 , at 316 ; R. Buel, supra note 101 , at 167 (paraphrasing Jacobs).

${ }^{304}$ It has been estimated that such a system could eliminate $15 \%$ of the truck trips into Manhattan. Tri-State Transportation Comm'n, Economics of a Rational Urban Pickup and Delivery System (1970), cited in J. Thomson, supra note 76, at 79. See J. JacoBs, supra note 80, at 346; McDermott \& Robeson, The Role of Terminal Consolidation in Urban Goods Distribution, in URBAN Goods MoveMENT, supra note 81, at 40.

A study of Manhattan indicates that over 25,000 trucks are involved in delivering goods daily within the nine square miles of the CBD with frequent overlapping of routes and stops. Trucks with an average freight capacity of 8 to 10 tons deliver only 1 to 1-1/4 tons of freight each day. A. Schwartz \& Associates, The Role of Trucks in the Region and Manhattan, quoted in J. Thомson, supra note 76, at 79. See Arrow, Coyle \& Ketcham, supra note 104 , at 81 .

Within the area covered by the Tri-State Transportation Commission it was found that " 430,000 trucks perform local trucking services and generate 11 percent of all vehicle-miles driven in the . . . area. One-third of these trucks do not move at all on any given weekday, and of those moving, about half carry no load." W. OwENs, supra note 3, at 61. See Survey, Freight, THE Economist, Nov. 16, 1974, at 24 (internal freight needs of Tri-State region require 2.8 million truck trips per day). In London the average delivery truck is on the move about one-eighth of its working day. Id. 25.

For the Tri-State Region, consolidation of shipments into twelve-ton loads for transport between off-street sorting terminals spaced about three miles apart in centers of truck activity could reduce transport between centers by about $90 \%$. J. THomson, supra note 76, at 94 (citing W. Owens, supra note 3). But see de Goyet, Railroad Terminals, Road Freight Terminals, in THE URBAN Movement of Goods 141-54 (1970) (in Brussels, such terminals generated more urban traffic by replacing one heavy vehicle by five to ten light vehicles); Survey, Freight, The Economist, Nov. 16, 1974, at 28 (transfer depots established north and south of Paris have not been successful because "costs have been much higher than expected").

${ }^{305}$ In Cologne, Germany, for example, deliveries by vehicle are permitted only between $6 \mathrm{a}$ am. and $10 \mathrm{a} . \mathrm{m}$. In other German cities, service traffic and access for residents by car is allowed after 9 p.m. and before 8 or 9 a.m. Kühnemann \& Witherspoon, supra 
deliver freight during off-peak hours. ${ }^{306}$ Such a plan would entirely eliminate some truck traffic, and it would offer a way for rail rapid transit systems to mitigate the economic effect of low demand for off-peak service. Finally, freight deliveries that must be made by truck might be facilitated, and interference with other street activities reduced, by restricting streets adjacent to pedestrian streets to delivery or service uses only. ${ }^{307}$ This would allow direct delivery to most CBD stores and offices.

The next concern is the movement of people into the CBD. This process should begin with two systems: existing urban mass

note 288 , at 64 . Such systems are strongly resisted by many merchants, who object to the necessity for maintaining staff on overtime to receive deliveries after hours, Survey, Freight, THE Economist, Nov. 16, 1974, at 29 (reason for failure of London "moondrop" experiment). See Orski \& Jakobsberg, Improvements and Innovations in Urban Goods Movement, in Urban Commodity Flow 100, 102 (Highway Research Bd. Special Rep. No. $120,1971)$. A British grocery chain, "Sainsbury," solved this prblem by adding a delivery area to each of its stores. Drivers are provided with a key to the outside door. This system still leaves the problem of drivers having to work at night, but the added cost here may be offset by the speed with which deliveries can be made at night. Survey, Freight, supra. Besides, much freight transport takes place at night now anyway. See generally Weiss, Labor Practices and Problems in Urban Goods Movement, in URBan Commodity Flow, supra, at $90,91-93$.

${ }^{306}$ Underground urban freight deliveries are not a new idea. There is, for example, a 6.5-mile underground postal service railway in London which operates automated trains between eight stations. See J. Fruin, Goods Movement on Urban Transit Systems, July 26-30, 1971, at 2 (ASCE-ASME Preprint No. 1521). The system carries more than 40,000 bags of mail daily and is estimated to save 1,700 truck trips per day. Residents of Chicago might be surprised to learn that there is a 62-mile underground freight delivery system which operated from the turn of the century to the late 1940's and was connected with all rail lines serving Chicago, ten public warehouses, and many of the Loop's major buildings. (The only section operating today delivers newsprint to the Chicago Tribune.) While the cost of tunneling under an existing city would be enormous, where excavations already exist, as in Chicago, or where underground rapid transit facilities exist, they ought to be utilized for freight deliveries. But see Arrow, Coyle \& Ketcham, supra note 102, at 86. Their principal arguments are that (1) there are no facilities for vertical movement of goods, (2) there is no storage space and/or sidings, (3) headways between trains are too small to permit loading and unloading, (4) stations are not "immediately adjacent" to business houses, and (5) the cost of additional transfer between truck and subway car "would probably be prohibitive." No data are cited in support of these arguments, however; nor are any studies referred to or cited. Mohr, supra note 81, at 105, 107. Mohr also points out the operational problems and notes that street congestion, low during off peak hours, would not be significantly affected by truck transport at night.

For a design for a freight tunnel to be added to the proposed Second Avenue subway in New York, see W. Breines \& J. Dean, The Pedestrian Revolution 142 (1974).

${ }^{307}$ This is the system in Munich. See Walter-Ulrich Jager, Environment Improvement in Center City, Sixth International Conference on Urban Transportation, in Official Proceedings: Marketing Urban Renaissance 145, 146 (1974). Bus and truck service could be integrated through refinement of the concept of "the European "articulated bus,' essentially a tractor that pulls either a freight or a passenger trailer." Goeller, Freight Transport in Urban Areas: Issues for Research and Action, in URBAN Commodity Flow, supra note 305 , at $149,158$. 
transit and walking. If rail rapid transit systems already exist, planners should begin with them. For although the case for new rail transit systems is extremely weak, this is not so for existing systems whose capital costs are sunk. Rapid transit stops in the central business district and selected bus lines in cities without rail rapid transit therefore become the initial planning points. Using each of these points as the center, a circle can be drawn to encompass the area served by any one stop, the radius of which is determined by the distance the transit user is willing to walk. ${ }^{308}$ The fragmentary data that exist indicate that the urban transit commuter will walk two or three blocks from his transit stop to his place of work. ${ }^{309}$ Within that walkable area, that is, a three block or thirteen hundred foot radius from a transit stop, private automobile traffic should be prohibited. This restriction is the ultimate goal. To minimize the expenditure of economic and political capital the plan should be implemented on a street-by-street basis.

Further refinements in the plan might permit access for taxicabs transporting the handicapped on service streets. A model for development might utilize the system of street "use

${ }^{308}$ See, e.g., RhODE ISLANd School of DESIGN, supra note 118 , at 114 .

A walkable distance is a function of the ambience. Thus shopping center studies indicate that the average shopper will not walk more than 600 feet from car door to shop door but will then walk 2,500 feet up and down supermarket aisles. The architect and planner, Victor Gruen, has found that a lazy walker on a single-purpose trip will travel 1,250 feet "[i]n an attractive but not weather-protected area during periods of inclement weather," 2,500 feet "[i]n a highly attractive environment in which sidewalks are protected from sunshine and rain," and 5,000 feet in "a highly attractive, completely weather-protected and artificially climatized environment." V. GRUEN, THE HEART OF Our Cities 249-50 (1964); Kwantes, Transportation Aspects of Multi Use Centers, 26 TRAFFiC Q. 517, 522 (1972); HUD BRIEF, supra note 80 , at 5 .

${ }^{309}$ See MEYER, supra note 3, at 188-89 \& Table 9. Interview data from New York City indicate a median walk to work from a subway stop of 1010 feet. See Pushkarev \& Zupan, Pedestrian Travel Demand, in Pedestrians 37, 52 (Highway Research Record No. 355, 1971). Data generated by the Tri-State Regional Planning Commission's 1963-64 home interview survey indicate that more than $85 \%$ of all trips involve less than four minutes of walking from transit mode to destination. See Fort, Walk Time from Vehicle to Final Destination, in Passenger Transportation Characterisitcs in Urban Areas 28, 31 (Highway Research Record No. 439, 1973). In trips to CBD destinations this study indicates that the average walk for those using automobiles was 1.17 minutes versus 4.66 minutes for mass transit passengers. Id. 30 (Table 1). But see Puskarev \& Zupan, supra, at 52 (Table 9). (The New York City data indicate a median walk from garage or parking lot of 1490 feet versus 1010 feet for the subway commuter.) The evidence is that the outer limits for walking to a bus stop from one's residence is $1 / 4$ mile or three blocks. Schmidt, et al., Specification and Evaluation of Alternative Feeder and Local Transit Systems in a Suburban Area, Public Transportation and Passenger Characteristics 37, 43 (Highway Research Record No. 417, 1972). For a formula to determine how many blocks can be served by a transit stop, see MEYER, supra note 3, at 190 . 
classifications" suggested by Victor Gruen in his famous Fort Worth plan and refined in his plan for Cincinnati. ${ }^{310}$ The seven use classifications in the Cincinnati plan were: pedestrians only; pedestrians and pedestrian carriers; pedestrians and limited truck use; express and local buses only; trucks only; shuttle buses, trucks, taxis, and pedestrians; automobiles, buses, trucks, and pedestrians. Given an average transit stop spacing of onehalf mile in central business districts, a completed traffic restriction program of this type will create a half-mile wide continuous automobile-free zone within the CBD. Buses might be permitted to cross the corridor at selected points, giving them a substantial time advantage over automobile traffic in transit from a point on one side of the corridor to a destination on the other side. ${ }^{311}$ Crossing points for automobiles would be severely limited, if provided at all. The atrophying effect of the original zones thus spreads. The next step would be to extend the restrictions and the resulting boundaries of automobile-free zones outward until the desired central city ambience is achieved..$^{312}$

A policy of automobile attrition by traffic restriction offers several advantages over policies heretofore considered. By physically barring vehicular traffic from a given street, problems such as the regressive effect of financial restraints, the problematic impact of daily versus monthly charges, and the necessity of relying on complex mechanical or labor-intensive enforcement techniques are avoided. More importantly, traffic restriction programs may be implemented on an experimental basis at little cost. $^{313}$ Because such experiments can be carried out by readily

310 V. GRUEN, supra note 308 , at 225, 234. For a similar proposal for Manhattan, see Gruen \& Ackwith, Plan to End Our Traffic Jam, N.Y. Times, Jan. 10, 1960, § 6 (Magazine), at 18. See also TRAFFIC IN Towns, supra note 84, at 50 (classification of streets for their primary function). Note, however, the criticism of dividing traffic into levels of "essentiality," Kain \& Beesley, supra note 84, at 180-81. The authors suggest "ease of substitution" as a more relevant criterion.

311 But see Cecilia, How to Improve Urban Traffic Conditions by Restraining Private Traffic-Preference of Public Surface Transport, in OECD, supra note 126, at 38.

312 Note that while the program would be implemented on a street-by-street basis the goal would be the creation of auto-free zones. See TrafFic IN Towns, supra note 84, \38 (Buchanan Report). The Buchanan Report took the idea from the "Radburn system," plan developed for the town of Radburn, New Jersey, in 1928 but which "seems to have had singularly little influence on American practice." Id. I 123. The main principle is the creation of an area free of vehicular traffic in which circulation is by pedestrian footpaths.

The zones will not be subject to the criticism leveled against "pedestrian malls" by Jane Jacobs, see J. JACOBS, supra note 80 , at 344 , and Victor Gruen, see V. GRUEN, supra note 308 , at $222-23$.

${ }^{313}$ HUD BRIEF, supra note 80 , at 25 . An experiment in traffic restriction in the 
reversible means, they can be implemented without awaiting time-consuming (and frequently incorrect) detailed analysis. Errors are easily corrected. Contrast this situation with a capital investment of a. billion dollars for a rail rapid transit system based on an analysis that turned out to be wishful thinking. It seems almost madness to commit vast resources to "new masstransportation systems-as proposed for Atlanta, Los Angeles, San Francisco, and Washington"-when even their most ardent champion confesses that the question "[w]hether [they] will attain traffic projected for them can be discovered only by building at least some of them."314

Increased public transit can be gradually phased in as the traffic restriction program evolves. To the extent possible, the traffic restriction plan should be implemented to focus each incremental restriction on as narrow a residential area as possible. Then additional transport capacity can be added along corridors most likely to reflect an increased demand for service. Because an increasing number of mass transit passengers will come from the automobile-owning classes, old myths about maintaining low transit fares to help the poor may at last be removed as governing principles of mass transit. Transit fares should be increased, so that the acquisition of new equipment will be financed out of increased revenues. The implementation of the traffic restriction plan should be coordinated with the capacity of the transit authority to acquire new equipment. Finally, when measured against the social costs of automobile commuting, the traffic restriction program offers assured amelioration of the damage. ${ }^{315}$

business district of Gothenberg, Sweden, for example, was implemented by blocking access roads with movable fences. Traffic restriction has also been used in Copenhagen, id. 10, and in New York City with the closing of the thoroughfare through Washington Square Park, J. JACOBS, supra note 80 , at 360-62 (predictions of dire traffic jams not borne out). Similar experiments could be attempted here with the ubiquitous police barrier or "sawhorse."

${ }^{314}$ L. FITCH, supra note 84, at 54.

${ }^{315}$ Experiments in New York, Marseilles, and Vienna indicate that traffic restriction will reduce carbon monoxide and noise levels. See Environmental Directorate, supra note 101, at I-21, V-2 to V-4; HUD BRIEF, supra note 80, at 2, 47; Lindquist, The Traffic Zone System in the City Core of Gothenburg, Sweden, in Parking as an ALTERAnt to THE Traffic Patrern 31, 32 (Highway Research Record No. 474, 1973); Parker \& Eburah, Oxford Street Experiment, Greater London Council Intelligence Unit Q. Bull., Dec., 1973 , at 18,19 (Figure 6). A traffic restriction program may also have a significant effect on motor vehicle accidents. In 1972 only $3 \%$ of all urban motor vehicle accidents involved collisions between a motor vehicle and a pedestrian, yet these accidents resulted in $39.9 \%$ of all traffic fatalities. During the first seven months of the Oxford Street experiment, there was a considerable reduction in serious pedestrian accidents. Parker \& Eburah, supra, at 17. 


\section{Street Use Planning}

An automobile attrition policy should be a major component of many communities' answer to the urban transportation problem. Such a policy would not only force commuters to switch to the more practicable modes of public transit, but would also make a central business district a more humane, enjoyable place to be. By making the district more attractive-through the creation of quiet yet bustling pedestrian malls, cleaner air, and other amenities-street use planning can fulfill a dual function of easing the transportation problem and retaining and acquiring business for the business district.

The attrition policy, of course, should be combined with the upgrading and expansion of public transit facilities in response to increased demand. Such improvements should not be effected to attract passengers with fancy hardware, but to upgrade service once demand has been demonstrated and the revenues raised from the fare box to pay for improvements. Without such improvements, the commuter who gives up his automobile may give up making his trip altogether, abandoning the central business district rather than shifting to alternate modes of transportation.

Successful implementation of such an attrition policy requires that a major role be played by the law and lawyers. Attorneys, of course, would fulfill their traditional role, designing and operating planning institutions. Street use planning also demands a far more complex analysis of underlying legal doctrine than does typical land use work. The use of streets involves a set of public and private legal relationships that existed long before zoning was a significant concept. Many of these relationships have been reexamined and altered by the street and highway construction boom of the 1950's and 1960's. Indeed, one of the ironies of the Interstate Highway Program is that the case law it spawned may facilitate the adoption of traffic restriction programs. But the combination of hoary doctrine and modern circumstance remains a major legal problem for street use planning.

The lawyer also has a heavy responsibility for structuring implementation of a program. Characterizations of actions may determine whether the community has the power to effect its plans and whether it must compensate owners of abutting property. Ancient doctrines and titles, if unanticipated, may have a significant impact on the results achieved. Finally, when com- 
pensation is necessary, the lawyer may discover a medium other than cash-"special benefits"-with which to pay the abutting owners. Because these problems arise on a block-by-block and even building-by-building basis, the lawyer must be an integral part of the planning team.

\section{A. The Power to Restructure Street Use}

The first legal question confronting the street use planner is whether the governmental body proposing to implement a program has the authority to do so. In the case of a municipal corporation, the extent of the delegation of power from the state must be scrutinized. In all cases, the validity of the exercise of power must be examined.

\section{Delegation of Authority from State to Municipality}

Plenary power over the streets and their use resides in the state. Municipalities have only such power over their streets as the state has delegated to them. ${ }^{316}$ Such delegations may be explicit $^{317}$ or implicit in more general grants. ${ }^{318}$ With either

${ }^{316}$ See, e.g., St. Louis v. Western Union Tel. Co., 149 U.S. 465 (1893); Grantham v. City of Topeka, 196 Kan. 393, 411 P.2d 634 (1966).

${ }^{317}$ Kentucky statutes, for instance, explicitly delegate authority to regulate street use. A public way is defined as "a public street, sidewalk, boulevard, avenue, road, lane, highway, parkway, court, or terrace." Ky. REv. STAT. ANN. $\$ 94.010$ (1971). The city council of a city of the second through sixth classes has authority to "exercise exclusive control over the public ways . . of the city. [The city legislative body] may establish, open, alter, widen, extend, close, grade, pave, repave, clean, sprinkle and repair the same . . . Id. $\$ 94.360$. The city council has power to "[I]icense, tax and regulate . . all vehicles using the streets . . . Id $\$$. 84.160 . Similar provisions in earlier Kentucky law, nearly identical in language, were sufficient to authorize the city of Somerset to enact an ordinance permitting the passage of "all carriers of freight and passengers by motor vehicle" only on such streets "as may be designated or approved by the Mayor and Board of Council of the City of Somerset, Ky." Bell Bros. Trucking v. Kelley, $277 \mathrm{Ky} .781$, 782-83, 127 S.W.2d 831, 832 (1939), discussed in Comment, Converting a City Street Into A Pedestrian Mall: Shade Trees, Fountains and Lawsuits, 28 U. PITT. L. REv. 293, 296-97 (1966).

${ }^{318}$ Compare, e.g., OkLa. Const. art. XVIII, §§ 2, 3(a), 7 and OkLA. Stat. AnN. tit. 11, $\$ \S 642,660,672$ (1959) with In re Grand River Dam Auth., 484 P.2d 505 (Okla. 1971).

The Ohio Supreme Court has held that a constitutional grant of "all powers of local self-government" includes a grant of the "power of complete regulation and control of the streets." Village of Perrysburg v. Ridgway, 108 Ohio St. 245, 255, 140 N.E. 595, 598 (1923) (validating village ordinance prohibiting buses from "starting and stopping" within its limits).

The right to frame a home rule charter, see, e.g., Mins. STat. Ans. $\$ 410.04$ (Supp. 1975), is itself a delegation of state authority. See, e.g., City of St. Paul v. Whidby, 295 Minn. 129, 203 N.W.2d 823 (1972). Therefore, a charter provision authorizing "care, supervision and control" of streets which permits changing an avenue from twoway to one-way traffic, Benson Hotel Corp. v. City of Minneapolis, $290 \mathrm{Minn} .14,17,187$ N.W.2d 610, 612 (1971), derives its force from that implicit delegation. 
form, the extent of municipal authority over streets is never clearly defined. Despite the delegations, the state often retains substantial authority over public highways and their use or, alternatively, vests conflicting authority in its various instrumentalities.

A typical conflict may arise when a city is granted general police power by one state statute or the state constitution but a separate state statute specifically restricts regulation of streets. The city of Madison, Wisconsin, for instance, attempted to establish exclusive bus and taxi lanes ${ }^{319}$ under a broad statutory grant of powers. ${ }^{320}$ The state vehicle code, however, provided that "[n]o local authority may enact or enforce any traffic regulation ... in any manner excluding or prohibiting any motor vehicle ... from the free use of all highways, except as authorized [in two other sections.]"321 Although one of the two exceptions was facially inapplicable, ${ }^{322}$ the other provided that the city could interfere with free use "to regulate heavy traffic." 323 The court found the "heavy traffic" section inapplicable by interpreting it to permit only restrictions that would bar use of all of a street or highway by "some" members of the public. Restrictions barring all members of the public from some part of a street or highway were impermissible. In support of its position, the court argued that if the general police power delegation were "all-inclusive" there would be no need for the exceptions to the vehicle code restrictions on local authority. The very existence of those specific exceptions was evidence that the general delegation of police power over traffic was not comprehensive. While a more imaginative court might have found the city's action permissible under the "heavy traffic" exception, the case is not so clearly wrong that counsel would have been able to give a clear opinion a priori as to the scope of the city's power in this case.

In Adley Express Co. v. Town of Darien, ${ }^{324}$ the Connecticut Supreme Court was faced with a conflict between a delegation of the regulation of traffic and a retention of the regulation of

${ }^{319}$ See City of Madison v. Reynolds, 48 Wis. 2d 156, 180 N.W.2d 7 (1970).

320 "Except as elsewhere in the statutes specifically provided, the [city] council shall have the management and control of the city property, finances, highways, navigable waters ..." Wis. Stat. ANn. \$ 62.11(5) (1957).

${ }^{321}$ Id. § 349.03(2) (1967), as amended (Supp. 1975).

${ }^{322}$ Id. $\S 66.046$ (1965) (permitting barricading of certain streets for play purposes). ${ }^{323}$ Id. § 349.17 (1971).

324 125 Conn. 501, 7 A.2d 446 (1939), discussed in Comment, supra note 317, at 297 n.28. 
motor vehicles. The court concluded that "while the state delegated to its municipalities the power to make traffic rules applying to all vehicles alike, the special power to regulate motor vehicles was retained by the state . . ."325 Therefore an ordinance banning through trucks from a certain street was invalid.

Counsel's task is not limited to attempting to reconcile the overlaps between state and local traffic regulation. Other state legislation may also conflict with the municipality's ability to implement a traffic restriction program. ${ }^{326}$ In Benson Hotel Corp. $v$. City of Minneapolis, ${ }^{327}$ the city acted under a charter provision, authorizing local control of the streets, to change Third Avenue South from a two-way to a one-way street. The Municipal Housing and Redevelopment Act conferred authority on the Minneapolis Housing and Redevelopment Authority ${ }^{328}$ (MHRA) to acquire property for the purpose, inter alia, of reducing traffic hazards and to install, construct, and reconstruct streets. ${ }^{329}$ When the city attempted to alter the traffic pattern within an area that the authority had set aside for urban renewal, it was objected that exclusive authority over streets within that area had been conferred on the MHRA. With a minimum of analysis the court concluded that the city retained the right to regulate traffic absent a "clear" legislative intent to "deprive the city of its inherent and traditional power to regulate traffic on its streets."330 The case could easily have been decided the other way.

Finally, home rule charters, enacted locally under authority

${ }^{325} 125$ Conn. at 505, 7 A.2d at 447 (emphasis supplied).

${ }^{326}$ In Sparrow v. City of Columbus, 40 Ohio App. 2d 453, 320 N.E.2d 297 (1974), the county commissioners attempted to vacate a portion of a road located within the City of Columbus. The Commissioners purported to act under the State code which provides that the "board of county commissioners may locate, establish, alter, widen, straighten, vacate, or change the direction of roads .... This power extends to all roads within the county . ..." Ohio Rev. Code ANN. \$ 5553.02 (Anderson Supp. 1974). The City of Columbus, on the other hand, claimed it had exclusive jurisdiction over streets within the city limits. The court found that the resolution lay in an interpretation of a home rule provision of the state constitution which provides that: "Municipalities shall have authority to exercise all powers of local self-government and to adopt and enforce within their limits such local police, sanitary and other similar regulations, as are not in conflict with general laws." OнIо CoNsT. art. XVIII, \& 3. The trial court had concluded that a street vacation was an exercise of police powers and that $\$ 5553.02$ was a "general law" which gave exclusive power to the county commissioners. The appellate court disagreed. It found that because the city had title to the street as trustee, only the city could dispose of it. Such a disposition would involve "an exercise in local self-government." 40 Ohio App.

$2 \mathrm{~d}$ at $457,471,320$ N.E.2d at $303,307$.

327290 Minn. 14, 187 N.W.2d 610 (1971).

${ }^{328}$ Minn. Stat. ANN. $\S \$ 462.411-.711$ (1963), as amended (Supp. 1975).

${ }^{329}$ Id. § 462.421(13) (1963), as amended (Supp. 1975).

330290 Minn. at $17-18,187$ N.W.2d at 612 . 
delegated by the state, may create conflicting loci of power. In Fifth Avenue Association, Inc. v. Lindsay, ${ }^{331}$ the city's Transportation Administration proposed to close Madison Avenue to all private vehicles, widen the sidewalks, and narrow the roadway from fifty-four to twenty-two feet. The Administration purported to act under charter provisions giving the Administration the power to regulate traffic ${ }^{332}$ and the power to design, construct, and repair public roads, streets, highways, and parkways. ${ }^{333}$ The court, however, construed the design and construction authority as limited to making changes necessary to fulfill the repair function. The Administration did not have the power to effect "a drastic transmutation of the very heart and soul of Madison Avenue."334 Instead the power to transmute remained with the Board of Estimate which, under the Charter, had "control of the streets of the city, except as in [the] charter otherwise provided." 335

Potential conflicts of these types may dwell in the statute and ordinance books of every jurisdiction. An initial step in implementing a street use plan, therefore, may have to be an articulation of the boundaries of authority within a state through advisory opinions and test cases.

\section{The Validity of Restructuring Street Use}

Even when authority is properly delegated, the question may arise whether any entity, state or local, may legitimately enforce the restructuring of street use. Attacks on such restructuring may allege that the actions are outside those that protect the general welfare, that is, outside the police power; that the actions are not reasonably related to their purposes; or that the actions involve arbitrary and discriminatory classifications. Imposition of traffic restrictions must be in furtherance of the public health and safety, that is, within the police power. In light of the social costs of automobile commuting, ${ }^{336}$ this requirement should present little difficulty. The lawyer should nevertheless relate each restriction to a particular police power issue. ${ }^{337}$

${ }^{331} 73$ Misc. 2d 111, 341 N.Y.S.2d 473 (Sup. Ct. 1973).

332 N.Y. City Charter § 2103(1)(b) (1972).

${ }^{333} I d$. $\S 2103(3)(\mathrm{b})$.

33473 Misc. $2 \mathrm{~d}$ at 114,341 N.Y.S.2d at 476.

${ }^{335}$ N.Y. CITY CHARTER $§ 326$ (1972).

${ }^{336}$ See notes 88-127 supra \& accompanying text.

${ }^{337}$ But of. City of Chicago v. McKinley, 344 Ill. 297, 176 N.E. 261 (1931), in which the court sustained an ordinance limiting "standing" time in a large area of downtown 
The cases evidence few justifications for traffic regulation insufficient to support exercise of the police power. In Salomone v. City of Canton, ${ }^{338}$ however, the city attempted to justify a 1958 no-parking ordinance with a 1956 traffic survey. The court held that the two-year-old study was insufficient support and struck down the ordinance. More typical is Chicago National Bank v. City of Chicago Heights. ${ }^{339}$ There the city council restricted a shop-lined street to use by pedestrians and police, fire, and emergency vehicles. A planning commission study that recommended that the street be converted into a pedestrian mall was held to provide sufficient support for the exercise of the power.

Until recently traffic studies such as those in Salomone and Chicago Heights were the typical justifications for traffic restrictions. The findings sufficient to sustain action under the police power were conveniently summarized by the California Supreme Court in Simpson v. City of Los Angeles, ${ }^{340}$ a case involving the closing to vehicular traffic of a cross street connecting two thoroughfares. The court found that the action was justified by the police power when (1) movement on the thoroughfares would be interfered with less if the cross streets were closed, (2) traffic on the cross streets was not essential to the orderly flow of traffic, (3) the best use for the street was for pedestrian traffic, and (4) allowing vehicular traffic thereon would interfere with and endanger the safety of pedestrian traffic.

To the traditional police power concerns of traffic movement and pedestrian safety can now be added prevention of air and noise pollution. ${ }^{341}$ In Cincinnati Motor Transportation Association v. City of Lincoln Heights, ${ }^{342}$ for instance, these new grounds supported an ordinance prohibiting truck traffic from Shepherd Lane. In particular, the court found that heavy trucks traveling Shepherd Lane sometimes made it impossible for residents "to conduct normal conversation, that their sleep was sometimes in-

Chicago. Having decided that the ordinance was reasonable on its face, the court refused to consider whether the police power justifications flowing from traffic congestion must be present on each and every street in the designated zone. The determination of how to alleviate the "Ioss and inconvenience" arising from traffic congestion was a matter for the council unless clearly unreasonable.

${ }^{338} 30$ Ill. App. 2d 474, 175 N.E.2d 663 (1961).

${ }^{339} 14$ Ill. 2d 135, 150 N.E.2d 827 (1958), discussed in Comment, supra note 317, at 297-98.

${ }^{340} 4$ Cal. 2d 60, 47 P.2d 474 (1935), discussed in Comment, supra note 317, at 298-99.

${ }^{341}$ See notes 99-112 supra \& accompanying text.

${ }^{342} 25$ Ohio St. 2d 203, 267 N.E.2d 797 (1971). 
terrupted and that vibrations from the trucks had caused damage to residences. These circumstances indicate that the only feasible method by which the municipality could preserve its residential character was for it to regulate truck traffic by ordinance." ${ }^{343}$ Counsel's task in establishing a justification for the exercise of police power then ought not to be onerous.

Given the justification to regulate, state courts will still investigate the substance of the regulation for "reasonableness." Traffic restrictions have been struck down by the conclusory phrases "arbitrary, unreasonable, capricious or oppressive . . . or [motivated by] malice or ill will."344 In reality the courts are redetermining questions settled by the legislatures (whether a particular regulation has a reasonable relationship to the goal to be achieved or whether the regulation is overbroad in that it reaches more than the conduct it is intended to cure) or they are vesting rights in the users of streets.

Haggenjos v. City of Chicago, ${ }^{345}$ for instance, was a case in which the court apparently failed to see a reasonable relationship between the problem and the solution. The problem, of course, was the effective regulation of downtown traffic. The solution was an absolute ban on vehicles' standing on any street in a specified downtown zone between 7 a.m. and 6:30 p.m. The delegation of power to the city was clear. A fifty thousand dollar traffic survey, characterized by the court as "exhaustive," justified the exercise of the police power. ${ }^{346}$ The court concluded, however, that the ordinance unreasonably failed to provide for standing for the purpose of delivering goods, without which the streets "would be of comparatively little use."347 The court was merely stating its judgment that the legislative judgment about the proper solution was wrong. The court apparently reached this determination on the face of the statute rather than on the facts of the case: first, because Mr. Haggenjos parked his car rather than "stood" outside his downtown office for thirty minutes, the court could have relied on well-established precedent supporting no-parking laws as reasonable; and second, Mr.

${ }^{343}$ Id. at 207,267 N.E.2d at 800.

${ }^{344}$ Bell Bros. Trucking v. Kelley, 277 Ky. 781, 785, 127 S.W.2d 831, 833 (1939)

(quoting Town of LaGrange v. Overstreet, 141 Ky. 43, 47, 132 S.W. 169, 170 (1910)).

345336 Ill. 573, 168 N.E. 661 (1929).

${ }^{346} I d$. at 575,168 N.E. at 663.

${ }^{347} I d$. at 578, 168 N.E. at 664 . 
Haggenjos was not among those who were unreasonably barred from the downtown zone. ${ }^{348}$

Haggenjos may still be used as precedent that restrictions banning deliveries to commercial establishments at certain times are arbitrary on their face. In some jurisdictions, its dictum that the power to regulate does not include the power to prohibit may still carry weight. But in Illinois, at least, this proposition has been undermined. ${ }^{349}$

The court in Chicago National Bank v. City of Chicago Heights, ${ }^{350}$ distinguishing Haggenjos, quite properly called the regulation/prohibition distinction a false issue. The court noted that cases that seemed to invalidate ordinances on the grounds of "prohibition" actually turned on questions of reasonableness. ${ }^{351}$ Thus even if prohibition is not completely ruled out, it still must be shown to be reasonable.

A different form of "reasonableness" test involves consideration of the narrowness of the statute. In Good Humor Corp. v. City of New York, ${ }^{352}$ the city passed an ordinance prohibiting the peddling of goods on any city street. The ordinance was enacted under the city's power with regard to the care, management, and use of its streets, as well as under the general delegation of police power contained in the city charter. The city offered evidence that "some 'itinerant peddlers' are unclean in their habits and are irresponsible, insolent, unfair and abusive in the manner in which they conduct their business; that at times some fraudulently use defective scales and measures; that some keep and store merchandise and offer it for sale in unsanitary manner . . .."353 In addition, the city argued that licensing procedures were ineffective because many of the vendors simply failed to obtain licenses. The court nonetheless carefully demonstrated that Good Humor avoided all the evils that the city sought to eliminate. The court continued:

${ }^{348} \mathrm{Id}$. at $575,577-78,168$ N.E. at $662-63$.

The ordinance was amended to permit up to three minutes of standing for reasonably expeditious loading and unloading of passengers and up to thirty minutes for freight. The ordinance was then upheld in City of Chicago v. McKinley, 334 Ill. 287, 176 N.E. 261 (1931).

${ }^{349}$ See Chicago Nat'l Bank v. City of Chicago Heights, 14 Ill. 2d 135, 150 N.E.2d 827 (1958).

350 Id.

351 Id. at 141,150 N.E. at 830.

352290 N.Y. 312,49 N.E.2d 153 (1943).

${ }^{353}$ Id. at 318,49 N.E.2d at 156 (emphasis in New York Reports only). 
An ordinance which prohibits a business so conducted because others conduct a similar business in manner which creates conditions which the public should not be compelled to tolerate, is patently unreasonable, at least where it does not appear that discrimination between the harmful and the harmless is impractical and that the public interest may be served better by complete prohibition than by further attempts at regulation. ${ }^{354}$

The converse of the overbroad ordinance is the law that solves only part of the problem, arbitrarily selecting one classification of contributors to the problem to be regulated while leaving another class untouched. Such classification is also subject to attack as unreasonable. A recent case considering the question is Great Lakes Motorcycle Dealers Association, Inc. $v$. City of Detroit, ${ }^{355}$ which involved the prohibition of the use of certain streets by two-wheeled motor vehicles. Despite evidence of excessive noise and speed, the court found the prohibition impermissible. The court viewed the relevant category as "motor vehicles" and thus found that "it is unreasonable and arbitrary to deny the use of the public streets to motorcycles, and yet, allow automobiles to continue to use those streets."

Such findings of arbitrary classification are, however, rare. Since the adolescence of the automobile era, for example, courts

${ }^{354} I d$. at $319, \overline{49} \bar{N} . \bar{E} .2 \mathrm{~d}$ at 156.

The court also used "reasonable relation" language, but it is difficult to see why an ordinance that admittedly would eliminate the harm the legislature intended to cure would be unreasonably related to the goal of the legislature. A secondary ground for the decision was that the city council had exceeded its police power. The court reached this ground because the council had received a report suggesting a ban on peddlers to "prevent unfair competition by itinerant peddlers with storekeepers who pay rent and various taxes ...."Id. at 317,49 N.E.2d at 155 . Such an object, the court said, was beyond the legitimate objectives of local government and so could not serve as a justification for exercise of the police power. But see Village of Perrysburg v. Ridgway, 108 Ohio St. $245,249,140$ N.E. 595, 596 (1923) ("A village might well contemplate that its merchants who own property in the municipality, and live in the municipality, contributing to its development and welfare and paying their taxes in the municipality, should not have as competitors upon its streets a line of street stores operated by motor busses [sic].") For another case of prohibited purpose see Hofstra College v. Board of Trustees, 145 N.Y.S.2d 323 (Sup. Ct. 1955), aff'd without opinion, 3 App. Div. 2d 712, 159 N.Y.S.2d 943 (1957) (closing to prevent through traffic to college beyond power of village).

35538 Mich. App. 564, 196 N.W.2d 787 (Ct. App. 1972). The court actually construed the statute as both too broad and too narrow. It first found the blanket prohibition against motorcycles overbroad because it applied to both the "Hell's Angels" and law-abiding riders. Without a pause the court addressed the arbitrary classification problem and then, again without pause, determined what the proper solution to the problem should be. The proper solution would be enforcement of the speed and noise ordinances. 
have permitted the regulation of motor vehicles without regulating "vehicles drawn by horses." This distinction was held not arbitrary because the horseless carriages "introduced a new element of danger to travelers on the highway." 356

Another attack on the exercise of the police power is that such action interferes with the vested rights of the users of a street. While certain rights are clearly recognized in owners of land abutting a street, ${ }^{357}$ some courts have also assigned rights in a street to the general public. Such an assignment may be inferred, for instance, from the language of a court overturning the creation of exclusive bus and taxi lanes: "[N]o matter how liberally we construed the police power of a city in relation to its streets we cannot find the right to discriminate against the general public's use of a one-way lane in a street for the benefit of only city buses and taxicabs." ${ }^{358}$ Despite the piling on of language of police power and discrimination, the court apparently meant that the city was taking the vested right of automobile and truck drivers to use the lane, to give it to another group, taxis and buses, without just compensation.

The problems with finding or recognizing such a right are multitudinous. While abutting owners may be relatively easily identified and compensated for infringement of their rights, a municipality would be hard pressed to compensate the "general public." Carried to an extreme, which is not too far from the initial premise, any individual who is in any way inconvenienced by any alteration of traffic patterns-implemented for purposes of safety, to increase speed of traffic, to decrease pollution, or whatever-would have a right to compensation. With such constraints, government regulation of traffic would cease.$^{359}$

Courts, however, have had little problem in upholding the banning of trucks from residential streets without compensating potential truck users. ${ }^{360}$ The facile explanation has been that the

${ }^{356}$ Commonwealth v. Nolan, 189 Ky. 34, 37, 224 S.W. 506, 507 (1920).

${ }^{357}$ See notes 362-434 infra \& accompanying text.

${ }^{358}$ City of Madison v. Reynolds, 48 Wis. 2d 156, 160, 180 N.W.2d 7, 10 (1970).

359 This point does not imply that members of the public would not have standing to challenge an "unreasonable" regulation.

${ }^{360}$ See, e.g., Cincinnati Motor Transp. Ass'n v. City of Lincoln Heights, 26 Ohio St. 2d 203, 267 N.E.2d 797 (1971). The court found that the availability of alternative routes, even though circuitous and considerably longer than those available before the truck ban, supported the reasonableness of the ordinance. Note that the inconvenience and denial of use of certain streets was not a taking. If absolutely no routes had been available, the question of right of access to one's own property would have arisen. That issue is clearly separable. 
general public holds an easement in a street, but that an individual common carrier or entrepreneur has only a mere privilege of engaging in gainful enterprise by participating in the right of passage. ${ }^{361}$ If this terminology were applied to traffic restrictions, those with a general right, the public, would be banned from the streets, and those with a mere privilege would be admitted to street use. On such an analysis the restrictions might be struck down. The absurdity of the result suggests the absurdity of the distinction. The better view is that the city holds the easement in the streets to fulfill its general welfare function, and those who have no abutting land, be they entrepreneur or individual, have no "vested" right in a particular mode or route of passage.

\section{B. The Abutters' Rights}

The principal legal issue raised by a street use plan, the issue on which the cost and ultimate feasibility of a program may turn, is the right of access of owners of land abutting public ways. The right of access of the abutting landowner is a legally protected, real property interest in the nature of an easement. ${ }^{362}$ At a minimum it is the right to enter and leave realty abutting a public way and the converse right to enter and leave the public way without being forced to pass over the land of another. ${ }^{363}$

${ }^{361}$ See, e.g., Village of Perrysburg v. Ridgway, 108 Ohio St. 245, 140 N.E. 595 (1923); Hadfield v. Lundin, 98 Wash. 657, I68 P. 516 (1917).

${ }^{362}$ See, e.g., Morrison v. Thelberg, 87 Ariz. 318, 350 P.2d 988 (1960) (easement of ingress and egress); People v. Ricciardi, 23 Cal. 2d 390, 144 P.2d 799 (1944) (easement); Clokey v. Wabash Ry., 353 Ill. 349, 187 N.E. 475 (1933); Department of Highways v. Linnecke, 86 Nev. 257, 468 P.2d 8 (1970) ("special right of easement for access purposes"); Dr. T.C. Smith Co. v. State Highway Comm'n, 279 N.C. 328, 182 S.E.2d 383 (1971) (easement appurtenant). See also $3 \mathrm{H}$. Tiffany, The Law of Real Property $\$ 927$ (3d ed. 1939) (rights inherent in nature of highway-incident to ownership of abutting land-not an easement but analogous to it).

On the origin of the right, see the dissenting opinion of Mr. Justice Holmes in Muhlker v. New York \& Harlem R.R., 197 U.S. 544, 571 (1905).

${ }^{363}$ See cases collected in 10 E. McQuillin, THE LAw OF MUNicipal Corporations $\S$ 30, at 649 n.65 (3d ed. 1966). See also Surety Sav. \& Loan Ass'n v. State Dep't of Transp., 54 Wis. 2d 438, 444, 195 N.W.2d 464, 467, appeal dismissed, 409 U.S. 810 (1972): "[T] he right of access involves only the right to enter and leave the property without being forced to trespass across the land of another." But $f$. Campbell v. State, 39 App. Div. 2d $615,617,331$ N.Y.S.2d 75, 77 (1972), aff d mem., 32 N.Y.2d 952, 300 N.E.2d 736, 347 N.Y.S.2d 205 (1973). There claimant owned a tract which did not abut on a public highway. To gain access to the highway he crossed three other tracts "with the permission or acquiesence of the various owners" although he "did not have an easement or right of way." The state took a strip along the northern boundary of claimant's land and thereby blocked his access to the old highway.

Whatever the legal nature of the access before the taking, the fact is that it was 
The public way to which access relates must in turn be connected to the general system of public streets. ${ }^{364}$

\section{The Right of Access and Compensation}

The questions on which a restriction program turns are how much intrusion on this right is permissible without compensating the abutting landowner, and what deprivations must be compensated. To say that the answers given by the courts have been muddled is an understatement. As the United States Supreme Court observed nearly seventy years ago in Sauer $v$. New York:

The right of an owner of land abutting on public highways has been a fruitful source of litigation in the courts of all the States, and the decisions have been conflicting, and often in the same State irreconcilable in principle. The courts have modified or overruled their own decisions, and each State has in the end fixed and limited, by legislation or judicial decision, the rights of abutting owners in accordance with its own view of the law and public policy. ${ }^{365}$

Since Sauer the confusion has been compounded by a new wave of litigation concerning the Interstate Highway Program. Much of that program has consisted of the conversion of existing roads and highways to limited access highways which have affected the physical access of the abutting landowners. In the process of working out the circumstances under which landowners should receive compensation for loss of access, the courts have left the law in this area in a "shambles."366 Thus, fifty-six years after Sauer, the Supreme Court of New Mexico could note that:

used by claimant without objection from the time he acquired the property in 1941 and by others before him as early as $1909 \ldots$. . [T] $]$ he question in determining whether or not claimant is entitled to consequential damages is whether or not he has been deprived of this access-not the quality of it.

On the definition of "abutter," see, e.g., Royal Transit, Inc. v. Village of W. Milwaukee, 266 Wis. 271,63 N.W.2d 62 (1954).

${ }^{364}$ See, e.g., United States v. Smith, 307 F.2d 49 (5th Cir. 1962), quoted and discussed in Stoebuck, The Property Right of Access Versus the Power of Eminent Domain, 47 TExas L. Rev. 733, 735 (1969); Breidert v. Southern Pac. Co., 61 Cal. 2d 659, 394 P.2d 719, 39 Cal. Rptr. 903 (1964); People ex rel. Dep't of Pub. Works v. Becker, 262 Cal. App. 2d 634, 69 Cal. Rptr. 110 (Ct. App. 1968); James v. State, 88 Idaho 172, 397 P.2d 766 (1964). See also Jennings v. Patterson, 488 F.2d 436 (5th Cir. 1974) (allegation of denial of access on grounds of racial discrimination held violation of 42 U.S.C. \$ 1985(3) (1970)).

365206 U.S. 536, 548 (1907).

${ }^{366}$ Annot., 42 A.L.R.3d 13, 21 (1972). 
The authorities are in hopeless conflict on this subject. It would seem that this is one phase of the law upon which the courts, sometimes even within the same jurisdiction, have adopted seemingly inconsistent views, and, in addition, in almost all of the cases, there are either vigorous dissents or special concurring opinions which join in the result only. There seems to be a radical difference in viewpoint among justices who have been required to rule upon the point. This conflict is so pronounced that most of the cases contain lengthy dissertations expounding the views of the author of the opinion or the dissent. ${ }^{367}$

One clear source of confusion is the line of cases that tries to distinguish between compensable and noncompensable damages in terms of "the police power." Financial loss resultant from the exercise of the police power is, we are told, damnum absque injuria. ${ }^{368}$ Yet if this is so and only damages from actions outside the police power'are compensable, then the traffic restriction programs will have little trouble. For if the action is outside the police power, as we have seen, the municipality cannot act at all. ${ }^{369}$ Therefore any permissible action would be noncompensable. This makes no sense. Clearly "police power" is being used as a meaningless label. Professor Arvo Van Alstyne put it aptly:

[T] $]$ he "police power" rubric employed to justify denial of compensation in cases where alleged property value depreciation has been caused by "traffic regulations," describes only the result; it does not advance supporting reasons. ... . [T] he "police power" approach lends itself to mechanical application with potentially irrational results. ${ }^{370}$

${ }^{367}$ State v. Danfelser, 72 N.M. 361, 364384 P.2d 241, 243 (1963). Whether deprivation of reasonable access has occurred is sometimes a question of fact, see State Highway Comm'n v. Smith, 248 Iowa 869, 82 N.W.2d 755 (1957); Henderickson v. State, 267 Minn. 436, 127 N.W.2d 165 (1964); W.E.W. Truck Lines v. State Dep't of Roads, 178 Neb. 218, 132 N.W.2d 782 (1965); Slepian v. State, 34 App. Div. 2d 880, 312 N.Y.S.2d $338(1970)$. The question is sometimes treated as a question of law. See, e.g., People v. Ricciardi, 23 Cal. 2d 390, 144 P.2d 799 (1943); Brock v. State Highway Comm'n, 195 Kan. 361, 404 P.2d 934 (1965); Stefan Auto Body v. State Highway Comm'n, 21 Wis. 2d 363, 124 N.W.2d 319 (1963).

${ }^{368}$ See, e.g., Johnson v. United States, 479 F.2d 1383 (Ct. Cl. 1973); FarmersKissinger Market House Co. v. City of Reading, 310 Pa. 493, 165 A. 398 (1933).

${ }^{369}$ See notes 336-60 supra \& accompanying text.

370 Van Alstyne, Just Compensation of Intangible Detriment: Criteria for Legislative Modifications in California, 16 U.C.L.A.L. REv. 491, 507 (1969) (footnote omitted). 
Therefore the attorney must look to a variety of factors to determine the probability that compensation will be required. Certainly he must consider the nature of the damages to the abutter, the rationale for the municipal action, and the alternatives open to the municipality. Ultimately he must determine whether the highest and best use of the property has been affected.

If a municipality built a fence completely surrounding a private parcel, rights of access would clearly be infringed and compensation due. But the concept of right of access contains major ambiguities. For instance, the question must be asked: What mode of access? Take the residential situation in which an ordinance prohibits $X$ from driving his car on the street in front of his house. $X$ must now park one block away and walk to his house. Has his right of access therefore been "damaged" or "taken"? The answer is "no" if access means physical accessibility because $X$ can walk from his car to his house. The answer is "yes," however, if access means entering his property from the public way by automobile. ${ }^{371}$ Because a traffic restriction plan involves a separation of transportation modes and their redistribution on the streets of the central business district, a more precise definition of access is critical. If the right of access means accessibility by any one of a wide variety of transportation modes, then the implementation of a street use planning scheme will give rise to claims for compensation by most abutters. Virtually no case law exists on this critical question.

One writer has suggested that the right of access be considered "the reasonable capacity of a landowner to reach the abutting public way by customary means of locomotion." 372 One of the few cases touching on the point sounds in a similar vein. In Hatfield v. Straus, the New York Court of Appeals held that the right of access includes "such means of conveyance for the

${ }^{371}$ In Breinig v. Allegheny County, 332 Pa. 474, 481, 2 A.2d 842, 847 (1938), the Pennsylvania Supreme Court held that "[a]n abutting owner undoubtedly has the right to place his car in a garage on his own lot and for the purpose of access thereto he may use the sidewalk, cutting the curb under municipal permit ...." But the court tempered its holding with a discussion of some general propositions:

First, a municipality cannot, without condemnation, completely shut off an abutting owner's access to his land, particularly pedestrian access. Second, in highly congested areas the right of vehicular access may be reduced to a minimum ... vehicular access may, in proper cases, be restricted to the hours of least congesId. tion.

${ }^{372}$ Stoebuck, supra note 364 , at 765 . 
transportation and delivery of goods and merchandise as are usual and customary." 373 While both formulations provide useful authority for the proposition that a municipality may act to regulate or prohibit access by modes that are not customary-a donkey or elephant, for instance-they are ambiguous on whether the right of access includes all customary modes. If not, does the right extend only to modes that have actually been utilized in the recent past and are customary or normal ${ }^{374}$ To modes that have been available?

The concept that access includes all reasonably available modes might by bolstered by the analogy of a line of abuse-ofeasement cases. In Marden v. Mallard Decoy Club, Inc.,${ }^{375}$ the court recently interpreted a 1799 grant of a cartway to include passage by automobile. The decision rested on the theories that an easement changes to serve the reasonable uses of the dominant estate and that easements may "be employed ... for the means of transportation in common use by a succeeding generation."376 With such a view applied to the right of access, the abutter might have constantly expanding modes available to him. The more reasonable view seems to be that the easement provides the dominant estate with the right to use a modern mode of transportation functionally equivalent to his accustomed mode. By analogy, a shift in mode brought about by exercise of the police power would not be compensable if the new mode adequately served the "reasonable uses" of the abutters.

Thus, the use of the abutting land as well as the abstract change in mode may be an important factor in determining levels of compensation. ${ }^{\mathbf{3 7 7}}$ In fact, no one has ever successfully argued that a gasoline station or motel cut off from a highway by new construction had suffered no taking of its right of access

${ }^{373} 189$ N.Y. $208,214-15,82$ N.E. 172,175 (1907).

${ }^{374}$ See Johnson v. United States, 479 F.2d 1383, 1391 (C.t. Cl. 1973).

375278 N.E.2d 743 (Mass. 1972); see McDonnell v. Sheets, 234 Iowa 1148, 1154, 15 N.W.2d 252, 255 (1944): "And it is the general rule that where a right-of-way is granted it may be used for any purpose to which the land accommodated thereby may reasonably be devoted ...."

376278 N.E.2d at 745 (quoting Swenson v. Marino, 306 Mass. 582, 587, 29 N.E.2d $15,18(1940)$. A third factor sometimes considered is whether the proposed mode materially increases the burden on the servient estate. See, e.g., Phillips v. Bonadies, 105 Conn. 722, 136 A. 684 (1927).

${ }^{372}$ But see Cicero Lumber Co. v. Town of Cicero, 176 Ill. 9, 51 N.E. 758 (1898). There the court held that an ordinance barring "traffic teams" (horse-drawn wagons) from a particular street, which was likely to drive the plaintiff out of business, did not give rise to a claim based on the right of access when the police power was validly exercised. 
because the facility could still be reached by bicycle or on foot. ${ }^{378}$ But it could be argued successfully that a motion picture theater in a central business district has suffered no taking when its street is converted to a pedestrian mall.

Aside from mode of access and use of land, it may be argued that a factor to be considered is which persons have been denied access to the property. The cases rarely explore the class of those who benefit from the abutter's right of access. Certainly the abutter himself is entitled to enter and leave the abutting property unhindered. So is his lessee. What of his invitees and licensees? This question does not arise normally because the abutter's route of physical access is also used by these other groups. For the traffic restriction program, however, the distinction may be significant. We might continue to allow freight vehicles to use a street for deliveries, but prohibit access to automobiles bringing customers or clients. Would such a restriction give rise to a claim on the part of an abutter? The few cases that have taken up the question directly have virtually assumed the conclusion that the abutter's right of access includes "patrons, clients, customers and visitors generally." 379

Another issue that an abutter may raise is that his route of access has been so elongated as to constitute a taking of his right. The rule is clear that damages resulting from circuity of access are considered damnum absque injuria. ${ }^{380}$ On the other hand, when remaining access is "unsuitable," compensation must be given. ${ }^{381}$ Again these terms are conclusory labels. The archetypal

${ }^{378}$ See, e.g., State v. Wilson, 103 Ariz. 194, 438 P.2d 760 (1968); Underwood v. State, 40 App. Div. 2d 749, 337 N.Y.S.2d 627 (1972).

${ }^{379} 10$ E. McQuillin, supra note $363, \S 30.63$. See City of Birmingham v. HoodMcPherson Realty Co., 233 Ala. 352, 172 So. 114 (1937); State v. Wilson, 103 Ariz. 194, 438 P.2d 760 (1968); Reining v. New York L. \& W. Ry., 13 N.Y.S. 238, 240 (Super. Ct.), aff'd, 128 N.Y. 157, 28 N.E. 640 (1891); Lenci v. City of Seattle, 63 Wash. 2d 664, 388 P.2d 926 (1964).

${ }^{380}$ The leading case is Smith v. Boston, 61 Mass. (7 Cushing) 254 (1852). See Johnson v. United States, 479 F.2d 1383, 1391 (Ct. Cl. 1973); Stanwood v. Malden, 157 Mass. 17, 31 N.E. 702 (1892); Buhl v. Fort St. Union Depot Co., 98 Mich. 596, 57 N.W. 829 (1894); Kings County Fire Ins. Co. v. Stevens, 101 N.Y. 411, 5 N.E. 353 (1886).

${ }^{381}$ See Priestly v. State, 23 N.Y.2d 152, 155, 242 N.E.2d 827, 829, 295 N.Y.S.2d 659, 662-63 (1968); Holmes v. State, 282 App. Div. 278, 279, 123 N.Y.S.2d 170, 171 (1953); Merritt Manor Estates, Inc. v. Village of Elmsford, 30 Misc. 2d 935, 941, 218 N.Y.S.2d 371,377 (Sup. Ct. 1961).

An alternative formulation contrasting "reasonable" with "unreasonable" access is occasionally found in the cases. See, e.g., Department of Pub. Works \& Bldgs. ex rel. People v. Mokres, 28 Ill. App. 3d 422, 328 N.E.2d 357 (1974). "It is readily seen that these words 'reasonable access' are the generators of uncertainty and trouble." New York, C. \& St. L.R.R. v. Bucsi, 128 Ohio St. 134, 142, 190 N.E. 562, 565 (1934). 
route case involves limited access highways: An abutting landowner previously could proceed from his land to a major thoroughfare, but with conversion of that road to a limitedaccess highway, the abutter is left with only a service or access road which, in turn, leads to the major thoroughfare. In Underwood v. State, ${ }^{382}$ for instance, respondents in an eminent domain proceeding were compensated for their loss of frontage on a state highway. To reach their filling station and restaurant, it had become necessary to travel "south 750 feet" along the highway, "then east 180 feet along the south edge of the leased premises, then north 460 feet to the enclosed area."383 And in State v. Wilson, ${ }^{384}$ Highway Number 86 , later known as Interstate 10 , had bisected condemnee's motel and guest ranch so that patrons could turn off the highway "directly" into condemnee's property.

[Following limited access conversion,] visitors no longer had direct access to the ranch but had to use the Dragoon Road Interchange, between 800 or 900 feet west of appellees' property. A traveler going east must take a ramp road 1500 feet west of the interchange, leave the ramp at Dragoon Road, turn south and go about three-quarters of a mile, then turn off Dragoon Road and turn onto the Wilson property, the building still being approximately 2000 feet away. A westbound traveler must go past the Wilson property, turn onto the interchange approximately 500 feet beyond the overpass of Dragoon Road and Interstate \#10, turn back to Dragoon Road, pass under Interstate \#10 and then go to the Wilson property on Dragoon Road in the same manner as the traveler coming from the west. ${ }^{385}$

Despite the fact that the journey probably consumed less time than reading a description of it, the court found that "the substitute access road is, in our opinion, unreasonably circuitous." 386

These holdings relate not only to route of access but sub silentio to the mode. The abutter's invitees and licensees in each

38240 App. Div. 2d 749, 337 N.Y.S.2d 627 (1972).

${ }^{383}$ Id. at 750,337 N.Y.S.2d at 628.

384103 Ariz. 194, 438 P.2d 760 (1968).

${ }^{385} \mathrm{Id}$. at 196,438 P.2d 762 (1968).

${ }^{386} \mathrm{Id}$. at $197,438 \mathrm{P} .2 \mathrm{~d}$ at 763 (emphasis supplied). The resolution of the issue of inappropriate remaining access, or "unreasonable circuity," is occasionally affected by whether the interference emanates from a "traffic regulation," for instance, the construction of a median barrier. See, e.g., Department of Pub. Works v. Logan, 198 Cal. App. 2d 
case can reach his premises only in their automobiles. To the extent the court focuses at all, its attention is therefore fixed on the increased difficulty of going from point $A$ to point $B$ in an automobile. The court has skipped the initial step of considering whether the automobile is necessary to the right of access. ${ }^{387}$ The cases may therefore be distinguishable were an attempt made to apply them to a traffic restriction scheme in an urban context, where it may be shown that automobiles are unnecessary.

In resolving these circuity cases, the courts provide some guidance for the street use planner. The tribunals attack these cases by citing two kinds of data. First, an opinion may recount the additional number of turns, with appropriate descriptions like "difficult," "narrow," "roundabout," and then add comments on increased distances, ${ }^{388}$ to convey an impression of the added "burden" placed upon one seeking access to the claimant's premises. Comparisons of the time necessary to enter the premises, before and after the change, are rarely considered. ${ }^{389}$ Second, the opinion may point to the decline in claimant's business due to the change in access. While the prevailing view is that loss of business earnings is not compensable, evidence of such is often used to support expert testimony that the change in access has altered the "highest and best use of the property" to the detriment of the claimant. ${ }^{390}$

581, 17 Cal. Rptr. 674 (Ct. App. 1961). Such reasoning has been correctly labeled "circular and spurious." Van Alstyne, supra note 370, at 503.

For a different approach, see State Highway Comm'n v. Finch, 237 Miss. 314, 114 So. 2d 673 (1959), in which the court read the Mississippi cases to hold that where a highway alteration "renders the abutting landowners' property less accessible to the highway" and where a Mississippi statute defines a "Controlled-access Facitity" as one "over, from or to which" abutters have only a controlled right of access, nothing more was needed to establish a "taking."

In Department of Pub. Works \& Bldgs. v. Wilson \& Co., 22 Ill. App. 3d 302, 317 N.E.2d 103 (App. Ct. 1974), the state took the defendant's entire frontage on a high volume traffic artery. It "proposed to build an access road to connect the remaining tract to a north-south residential street ... [which street] eventually intersects with [the traffic artery.]" The court found "a complete taking of access." Id. at 303, 305, 317 N.E.2d at $104,105$.

${ }^{387}$ See notes $371-78$ supra \& accompanying text.

${ }^{388}$ For cases collected and divided by number of feet, see Annot., 42 A.L.R.3d 13, 84-88 (1972).

${ }^{389}$ For one such rare consideration, see Calumet Fed. Sav. \& Loan v. City of Chicago, 306 Ill. App. 524, 29 N.E.2d 292, 295 (1940).

${ }^{390}$ See, e.g., State ex rel. Herman v. Wilson, 103 Ariz. 194, 438 P.2d 760 (1968). Serious alterations in the manner of doing business, as well as lost profits, may be marshalled to show a detriment to the highest and best use of a property. See, e.g., Holmes v. State, 282 App. Div. 278, 123 N.Y.S.2d 170 (1953). There, prior to the closing of a street entrance, claimants carried on ninety percent of their feed mill business with 
This reference to use is in fact the common thread of rationality that ties together the access cases in which courts have been willing to go beyond a mechanical recitation of the litany of police power versus the right of access. ${ }^{391}$ The leading case defining the right of access as a function of "the highest and best use of the property" is Priestly v. State ${ }^{392}$ The state rendered access to the abutting property more circuitous, but the court indicated that this circuity did not necessarily give rise to a compensable claim. Because the abutting property was vacant the court could point to no decline in patronage or substantial change in the volume of traffic to aid in drawing "the rather murky distinction" 393 between circuitous and unsuitable access. Instead the court indicated that analysis begins with establishing the "highest and best use of the property" before the change and then determining whether the remaining access has affected that use in a negative way.

In applying the Priestly rule, the court in Underwood $v$. State ${ }^{394}$ confirmed the finding that the changed access had rendered unsuitable the premises' highest and best use before the appropriation-some commercial business catering to the traveling public, such as a motel, restaurant, or gift shop-and resulted in a decline from the highest and best use to limited commercial development, such as trailer sales. This finding makes it clear that the description of the increased number of twists and turns and distances is at best a makeweight that merely confuses the real issue. The critical factor is not the added effort imposed on the abutter and his invitees and licensees, but whether they are willing to make that effort. ${ }^{395}$ If the

farmers who called upon the claimants' place of business. After the closing, access could be had only by a road that was difficult for customers to use; as a result, the claimants had to deliver over ninety percent of their sales. Claimants received compensation.

${ }^{391}$ See Mayberry \& Aloi, Compensation for Loss of Access in Eminent Domain in Nezu York: A Re-Evaluation of the No-Compensation Rule with a Proposal for Change, 16 Buffalo L. REv. 603, 620 (1967); Hendrickson v. State, 267 Minn. 436, 127 N.W. 165 (1964) (prohibiting or limiting access as exercise of police power does not preclude claim for eminent domain damages). For a discussion of the police power litany, see notes $368-70$ supra \& accompanying text.

39223 N.Y.2d 152, 242 N.E.2d 827, 295 N.Y.S.2d 659 (1968). Earlier New York cases include Red Apple Restaurant, Inc. v. State, 27 App. Div. 2d 417, 280 N.Y.S.2d 229 (1967); Holmes v. State, 282 App. Div. 278, 123 N.Y.S.2d 170 (1953). See generally Johnson v. United States, 479 F.2d 1383 (Ct. Cl. 1973); Chandler v. Hjelle, 126 N.W.2d 141 (N.D. 1964) (considering all uses to which the property is adaptable and for which it is needed or likely to be needed).

${ }^{393} 23$ N.Y.2d at 155,242 N.E.2d at 829,295 N.Y.S.2d at 662.

${ }^{394} 40$ App. Div. 2d 749, 337 N.Y.S.2d 627 (1972).

395 See note 390 supra \& accompanying text. 
number of patrons at Underwood's filling station or Wilson's guest ranch had increased after the highway was altered, it is submitted that the court would have had some difficulty in finding the new access route "unreasonably circuitous" or "unsuitable," despite the increased distance and number of turns.

An analysis more appealing from the twin vantages of logic and experience would recognize the right of access as a function of the highest and best use of land and would squarely face the fact that a decline in traffic or patronage can and usually will alter the highest and best use. ${ }^{396}$ But to adopt the "highest and best use" test does not amount to creating a right to compensation for a mere change in value of a property. ${ }^{397}$ Compensation would be available only for a change in the highest and best use, not for a change in value if the use remains or could remain the same. In United California Bank v. People ex rel. Department of Public Works, ${ }^{398}$ for instance, application of the test would have

${ }^{396}$ A major cautionary note to this approach is that the right of access is in the access and not in a particular flow of traffic. A long line of "diversion-of-traffic" cases has held that providing an attractive new route that lures motorists away from the route that abuts the owner's property is not compensable, even when the owner loses substantial business. People v. Ricciardi, 23 Cal. 2d 390, 144 P.2d 799 (1943) (dictum); see James v. State, 88 Idaho 172, 397 P.2d 766 (1964); Ray v. State Highway Comm'n, 196 Kan. 13, 410 P.2d 278 (1966); A.E. Nettleton Co. v. State, 11 App. Div. 2d 899, 202 N.Y.S.2d 102 (1960); Stefan Auto Body v. State Highway Comm'n, 21 Wis. 2d 363, 124 N.W.2d 319 (1963). The paradigmatic case grows out of a rural setting in which the owner of a roadside establishment loses business when a new limited-access throughway diverts traffic from the front of his establishment, although the old road is left in place. The costs of such diversion are particularly high for abutters in rural areas where land values are based solely on agricultural uses except where the land abuts highways and has valuable potential for gasoline stations, motels, and souvenir stands. See, e.g., Castellano v. State, 38 App. Div. 2d 652, 327 N.Y.S.2d 162 (1971) (value as agricultural land $\$ 650$ per acre; value for low intensity commercial development $\$ 7,000$ per acre).

The rationale for not socializing these losses may have been that the volume of claims would be so high the building of roads would be discouraged. See, e.g., Bacich v. Board of Control, 23 Cal. 2d 353, 364, 144 P.2d 818, 831 (1943) (concurring opinion) (rule broadening liability "might prove so burdensome as to stop or substantially decrease needed improvements").

These policy considerations would not generally apply in the central business district. The scope of possible land uses in a CBD is much wider than in a rural area. Thus any drop in traffic immediately abutting a CBD site is unlikely to have a significant negative impact on the site's highest and best use. In fact, experiments indicate that a traffic restriction program is more likely to upgrade the value of the land within the area covered by the program.

In terms of highest and best use, the diversion issue for CBD's is then not a serious problem. If diversion elevates the highest and best use, the owner cannot complain of a taking. Even if he could, he may be faced with a setoff of "special benefits." See notes 480-503 infra \& accompanying text.

${ }^{397}$ See, e.g., Meyer v. Richmond, 172 U.S. 82, 95 (1898); People v. Ricciardi, 23 Cal. 2d 390, 395-96, 144 P.2d 799, 802 (1943).

${ }^{398} 1$ Cal. App. 3d 1, 81 Cal. Rptr. 405 (Ct. App. 1969). 
resulted in no compensation, the opposite of the actual result. Compensation was sought for loss of exposure and access by a small department store as a result of street closings that prevented cars from stopping on an adjoining curb, construction of a roadway that impaired the view of the store, and turning the abutting streets into a parking lot. The jury awarded the owners $\$ 54,625$. If the highest and best use had been considered, however, the court would have followed the testimony of the experts for both sides that the highest and best use of the land remained as a small or medium-sized department store. ${ }^{399}$

The Priestly rule making access a function of highest and best use subsumes issues that are rarely, if ever, discussed in the case law, such as mode of transport and benefited group. An illustration of the satisfactory operation of the rule can be found in Castellano $v$. State. ${ }^{400}$ Appellant's cold-storage and fruitpacking building stood on a road that was "dead-ended." Large tractor-trailers which formerly had easy access to the building could then serve the building only by backing in or backing out

${ }^{399}$ A considerable refinement of the "highest and best use test" has been suggested by Professor Arvo Van Alstyne. Van Alstyne, supra note 370. To decide whether the remaining access is reasonable, Professor Van Alstyne has suggested a rather unwieldy though comprehensive statutory provision on the factors to be taken into account:

a. The extent to which the property retains direct access capabilities reasonably adequate for its highest and best use in light of (i) the nature and requirements of that use; (ii) the number, physical dimensions, and usefulness of access facilities; and (iii) any other circumstances relevant to effective utilization of the property, including reasonably available alternatives. ...

b. The degree to which the property enjoys general accessibility to the surrounding community, which is reasonably adequate in relation to its highest and best use, in light of (i) increased travel time and distance to normal destinations; (ii) greater hazards of traveling alternate routes; (iii) the practical unavailability of reasonable alternate routes; and (iv) the likelihood that visits to the property by members of the public (including commercial patronage) may decline due to difficulties in travelling between the general street system and the property.... c. The extent to which the claimed impairment of access may be regarded as reasonable and thus noncompensable because (i) the challenged governmental action has a primary purpose and effect of safeguarding public health, safety and welfare by means which would be substantially impaired or deterred by the cost of making just compensation, if required, and for which equally salutory alternatives, with less capacity for interfering with private access rights, are unavailable at equal or lower cost; (ii) the adverse impact of the governmental action upon access rights is so widely shared, speculative in nature or amount, or relatively slight that the cost of distributing such losses in the form of constitutional compensation would impose an unreasonable burden upon governmental finances, or upon the judicial system, or both; or (iii) the claimant's abutting land enjoys compensating special benefits derived from public improvement or from the practical operation of the regulatory measure.

Id. 512-15.

${ }^{400} 38$ App. Div. 2d 652, 327 N.Y.S.2d 162 (1971). 
two-tenths of a mile. As a consequence, of the three trucking lines that served appellant's business before the change, one refused to continue and the other two had to send smaller trucks or park their large trucks on the highway and move the goods from appellant's warehouse to those trucks by fork-lift. If the test were whether the limitation on access was "unreasonable,"401 "substantial," 402 or "material," 403 the case could have gone either way. ${ }^{404}$ Applying the Priestly rule, however, there could be only one outcome once the court confirmed that " $[t]$ he use of smaller trucks has not been shown in any way as detrimental to the commercial value of the property ...."405

The Castellano application of Priestly is important to a plan of traffic restriction. Its facts are an example of precisely the kind of modal change in freight delivery that would take place, for example, if freight delivery via rapid transit were found feasible and implemented. ${ }^{406}$ An alternative would be establishment of centrally located freight depots with local deliveries by smaller vans. ${ }^{407}$ Neither change should give rise to a claim for taking of or damage to the right of access without a showing of change in the highest and best use of the property. ${ }^{408}$

401 See, e.g., State ex rel. Herman v. Schaffer, 105 Ariz. 478, 467 P.2d 66 (1970).

402 See, e.g., James v. State, 88 Idaho 172, 397 P.2d 766 (1964).

${ }^{403}$ See, e.g., State v. Geiger \& Peters, Inc., 245 Ind. 143, 196 N.E.2d 740 (1964).

404 See, e.g., Bacich v. Board of Control, 23 Cal. 2d 343, 366, 144 P.2d 818, 831

(1943) (concurring opinion).

40538 App. Div. 2d at 653,327 N.Y.S.2d at 165.

${ }^{406}$ See note 306 supra \& accompanying text.

${ }^{407}$ Note 221 supra \& accompanying text.

${ }^{408}$ In the recent case of La Briola v. State, 36 N.Y.2d 328, 328 N.E.2d 781, 368 N.Y.S.2d 147 (1975), the New York Court of Appeals preserved an unsatisfying distinction between damage due to loss of access and damage due to traffic diversion. Claimant's land formerly abutted Route 22. That route was relocated, reducing claimant's frontage on the highway from 1100 feet to 165 feet. In addition an access ramp 150 feet in length was constructed connecting claimant's land with the new road. As a result of these changes the highest and best use of claimant's land was reduced from retail to light industrial. While Priestly would seem to militate in favor of compensation in this case, the Court of Appeals felt that case was not applicable. "Put another way, the key to the resolution of the issue in this case is that the reduction in highest use of claimant's property was caused not by loss of suitable access but by the loss of abutment on a highway and its profitable traffic." Id. at 334,328 N.E.2d at 785,368 N.Y.S.2d at 153 . In the view of the Court of Appeals, the case turned on the factual finding by the Court of Claims that it was "the non-compensable diversion of traffic by the construction of the new highway [which] destroyed the old highest use for [the] roadside business." Id. On the other hand "[i]f the State's appropriation of highway-abutting land (true frontage), or the physical construction of the improvement itself, so impairs access to the remaining property that it can no longer sustain its previous highest and best use, then the State must pay consequential damages to the owner ..." Id. at 332, 328 N.E.2d at 783-84, 368 N.Y.S.2d at 151 (citing Priestly). 
Castellano also sheds light on the question of access points. Suppose the property in question is in the middle of a central business district block and abuts streets to the front and rear-a typical situation. When municipal action results in the barring of vehicular access to the property from one of the streets, has the right of access been taken or damaged? ${ }^{409}$ As a result of the changes in Castellano, "only one point of entry and exit remained where there were formerly three ...."410 Yet without the effect on highest and best use no compensation needed to be paid. ${ }^{411}$ In Lysaght $v$. City of Fort Worth ${ }^{412}$ the city converted the abutting street upon which the landowner had his loading dock into a limited access freeway. His premises could no longer be served by "large six-wheel trucks." In denying his claim for compensation the court found that "ordinary trucks" continued to have access to his building from an alley in the rear. The approach in those two cases seems more attractive than the usual mechanical ones of noting that the reduction in the number of access points is automatically a taking or damaging of the right of access ${ }^{413}$ or that access need not be provided at every point. ${ }^{414}$

${ }^{409}$ For a list of states in which the exercise of the eminent domain power gives rise to a claim for compensation if property is "damaged" see Stoebuck, supra note 364, at 734 n.2. The broader constitutional protection existing in these states has not led to a wider conception of the right of access. See, e.g., Darnall v. State, 79 S.D. 59, 108 N.W.2d 201 (1961).

41038 App. Div. 2d at 653, 327 N.Y.S.2d at 165.

411 A more conventional analysis was utilized in City of Waco v. Archenhold Auto. Supply Co., 386 S.W.2d 174 (Tex. Civ. App.), aff'd, 396 S.W.2d 111 (1965). A viaduct constructed in an abutting street blocked the loading platform of a corner property. Despite a finding that the viaduct was an inconvenience and a limitation on the customer's access to the loading dock and despite a jury verdict that the market value of appellee's property had been reduced, the court found no compensable injury on the dual grounds that the construction of the viaduct by the city was a valid exercise of its police power and that appellee had not been denied total access to its property.

${ }^{412} 359$ S.W.2d 128, 129, 131 (Tex. Civ. App. 1962).

${ }^{413}$ See, e.g., Brownlow v. O'Donoghue Bros., Inc. 276 F. 636 (D.C. Cir. 1921) (closing one driveway entrance to corner lot on which claimant maintained a gasoline station gave rise to compensable claim despite fact that claimant had access from other street and that closing was to protect endangered pedestrians); State v. Diamond Lanes, Inc., 251 Ind. 520, 523-24, 242 N.E.2d 632, 634 (1968). Contra, Johnson v. United States, 479 F.2d 1383, 1390-91 (Ct. Cl. 1973) ("[T] he owner is not entitled to access to his land at any and all points in the boundary between it and the highway."); State Highway Comm'n v. Smith, 248 lowa 869, 875, 82 N.W.2d 755, 759 (1957).

${ }^{414}$ See, e.g., Fowler v. City of Nelson, 213 Mo. 82, 246 S.W. 638 (Ct. App. 1923). 


\section{Abutters' Rights and Street Use Planning- Special Problems}

\section{a. The "Piazza" Principle}

One of the most pleasant images conjured up by imaginative planners is an inner city of squares, piazzas, or areas similar in function where pedestrians can sit or stroll without the intrusion of motor vehicles. That such urban amenities can also be made to serve a traffic restriction function has long been known to planners. ${ }^{415}$ The restriction effect is obtained by "dead-ending" a street at a square. By dead-ending four streets at an intersection a square or piazza is created. "Dead-ending" or creating a cul-de-sac automatically eliminates through traffic and serves to discourage even locally-destined vehicular traffic. The closing of one end of a street to create a cul-de-sac is one of the more common types of action affecting the right of access. A separate line of access cases deals with culs-de-sac.

Courts generally apply two theories to deny recovery to abutters on a cul-de-sac street. The first is that the injury to the abutter is different in degree but not in kind from the harm to the general public. ${ }^{416}$ This point recognizes that the impact of a cul-de-sac is primarily on through traffic. The abutter's driveway or existing means of entry or exit is rarely blocked or altered. Usually the creation of a cul-de-sac occasions at most a journey around the block, a distance which the courts hold almost as a matter of law not unduly circuitous. ${ }^{417}$ The second theory upon which recovery is ordinarily denied is the "one-way" street analogy. The right of a municipality to convert a street from a twoway street to a one-way street in the interests of better traffic management has long been held to be noncompensable. ${ }^{418}$ The

415 The street pattern of the typical $C B D$ in the United States is a grid pattern "designed to equalise the flow of traffic on parallel streets by giving motorists numerous alternative routes of equal length. This pattern is intended to maximize average traffic speed for a given lane-mileage [and] is intended to serve the interests of traffic movement." Contrasting with the grid pattern is the cul-de-sac pattern which confines traffic to the principal through roads and is intended to serve environmental objectives. J. Thomson, supra note 76, at 12.

${ }^{416}$ New York, C. \& St. L.R.R. v. Bucsi, 128 Ohio St. 134, 190 N.E. 562 (1934). See also In re East 5th St., 1 Misc. 2d 977, 146 N.Y.S.2d 794 (Sup. Ct. 1955); cases collected in 2A P. Nichols, The Law of Eminent Domain \& 6.4443[3] n.15 (3d rev. ed. 1975).

${ }^{417} \mathrm{Cf}$. notes $380-95$ supra \& accompanying text.

${ }^{418}$ See, e.g., Bacich v. Board of Control, 23 Cal. 2d 343, 372 n.1, 144 P.2d 818, 835 n.3 (1943) (dissent) (dictum); Beckham v. City of Stockton, 64 Cal. App. 2d 487, 149 P.2d 296 (Ct. App. 1944) (dictum); State ex rel. State Highway Comm'n v. Danfelser, 72 N.M. 361, 384 P.2d 241 (1963) (dictum). See also Eighth Ave. Coach Corp. v. City of New York, 
negative effect of the cul-de-sac is the same as the conversion of a street to one-way traffic in the direction of the barrier creating the cul-de-sac. In both cases one cannot enter the street from the barred end. The general assertion is that the abutter's right of access "does not include the right to travel in any particular direction from one's property." 419

Like all assertions, this one can be, and has been, contradicted. In the leading California case of Bacich $v$. Board of Control, the California Supreme Court noted that "[i]t would seem clear that the reasonable modes of egress and ingress would embrace access to the next intersecting street in both directions." ${ }^{20}$ Why this is "clear" is not apparent from the opinion. It was, in fact, this lack of clarity that led to a vigorous dissent by Justice Traynor who noted that the majority begged the question by simply redefining the right of access. ${ }^{421}$ This socalled "next intersecting street" rule has the attraction of precision and predictability but the weightier drawback of a lack of foundation in either logic or experience. ${ }^{422}$ As traffic planners have noted, the main impact of creating a cul-de-sac is the barring of through, but not of local, traffic. The rule is well settled that an abutter has no legal right in the volume of traffic. ${ }^{423}$ Thus the abutter cannot state a legally cognizable complaint about this effect. The basis for his claim, if any, is the necessity of making a U-turn where none was required before. ${ }^{424}$ The "cost" of the

170 Misc. 243, 10 N.Y.S.2d 170 (Sup. C. 1939), aff'd, 286 N.Y. 84, 35 N.E.2d 907, 20 N.Y.S.2d 401 (1940).

${ }^{419}$ State $e x$ rel. State Highway Comm'n v. Meier, 388 S.W.2d 855, 857 (Mo.), cert. denied, 382 U.S. 846 (1965). See also In re East 5th Street, 1 Misc. 2d 977, 982, 146 N.Y.S.2d 794, 800 (Sup. Ct. 1955) (at common law "[a]ccess had to be preserved but not necessarily in both directions . ..."); Fearing v. Irwin, 55 N.Y. 486 (1874) ("though one public way to property is closed, if there is another left, the property owner sustains no actionable damage." [footnote omitted]).

42023 Cal. 2d 343, 352, 144 P.2d 818, 824 (1943), discussed in Van Alstyne, supra note 370 , at 494 .

421 Justice Traynor noted that the trust that arises from the appropriations of land for public thoroughfares is for the benefit of the public at large and only incidentally for the benefit of the abutting owners. "The extension of the abutting owner's rights in the present case makes the primary consideration the benefit of abutting owners rather than the benefit of the public." 23 Cal. $2 \mathrm{~d}$ at 371,144 P.2d at 834 .

${ }^{422}$ See Van Alstyne, supra note 370, at 494-95.

${ }^{423}$ See note 396 supra.

${ }^{424}$ But see New York, C. \& St. L.R.R. v. Bucsi, 128 Ohio St. $134,139-40,190$ N.E. 562, 564 (1934): "If we let one hundred per cent equal their right of access to their property prior to the date of the vacation ... [ [of one end of the street], then fifty per cent must represent it now. Prior to the date of this improvement they could travel in two directions. Now they can travel in but one direction in order to get into communication with the street system of the city." 
U-turn may range from a minimal exertion of effort to the loss of immediate proximity to transportation modes unable to negotiate the turn. Against recognition of claims in compensation for these losses must be weighed the social costs of determining, litigating, and satisfying such claims. It is not surprising then that a majority of jurisdictions deny compensation for closing one end of a street. ${ }^{425}$

\section{b. "Squeezing"}

The narrowing of a thoroughfare, cutting down its absolute capacity to carry automobiles, may be an effective tool of street use planning. At first glance, a narrowing may seem to impinge on a compensable right to light and air. But the leading cases recognizing such a right generally involve a narrowing of the open space by construction in the former thoroughfare ${ }^{\mathbf{2 6}}$ or the operation of a steam railroad therein. ${ }^{427}$ Far from diminishing light and air quality, contemporary street narrowing accomplished by sidewalk expansion enhances full enjoyment of those attributes. In implicit recognition of this benefit, the courts should treat questions of the width of streets as involving only the legal right of access. ${ }^{428}$

\section{c. Leveling}

Reconstruction of central business district streets to bring them up to sidewalk level may facilitate pedestrianization of those streets and traffic restrictions generally. Such reconstruc-

${ }^{425}$ New York, C. \& St. L.R.R. v. Bucsi, 128 Ohio St. 134, 190 N.E. 562 (1934). See, e.g., Meyer v. Richmond, 172 U.S. 82 (1898); Krebs v. State Roads Comm'n, 160 Md. 584, 154 A. 131 (1931). Cases finding compensable damage for the creation of a cul-desac are collected in Bacich v. Board of Control, 23 Cal. 2d 343, 353, 144 P.2d 818, 829 (1944).

A special cul-de-sac rule apparently exists in New York. While conceding that as long as "some means of access was made available" the common law right of access was not taken or damaged, the court in In re East 5th St., 1 Misc. 2d 977, 986, 146 N.Y.S.2d 794, 804 (Sup. Ct. 1955), recognized the "ancient street doctrine" which gives landowners a "private easement" to have access from each end of the block when "it appears that a common grantor has by deed dedicated the street to the use of all grantees ...." The rule applies "only when it is shown that the dominant tenement (ownership of the land) and the bed of the street were once the property of a common grantor." Id. at 985, 146 N.Y.S.2d at 803.

426 See, e.g., Fry v. O'Leary, 141 Wash. 465, 252 P. 111 (1927).

${ }^{427}$ See, e.g., Adams v. Chicago, B. \& N.R.R., 39 Minn. 286, 39 N.W. 629 (1888).

${ }^{428}$ See, e.g., City of Houston v. Fox, 444 S.W.2d 591, 592 (Tex. 1969) (no "property right in any particular type or size of street"; only claim based on impairment of access cognizable). See also Brown v. Board of Supervisors, 124 Cal. 274, 281, 57 P. 82, 84 (1899): Narrowing of Turk Street from 100 feet to 68 feet, 7 inches was not compensable 
tion provides a physical barrier to vehicular use. At the same time it eliminates a major travel barrier for the handicapped - the street curb. Finally, the plaza-like appearance encourages pedestrians to cross back and forth among shops, something they may be reluctant to do with a vehicle-free but still extant street bed.

An objection that could be raised against such street leveling is that the alteration constitutes a change of grade. Whether a change in level of a few inches is a change of grade is arguable. No cases resolve the question; typically a change of grade involves several feet. ${ }^{429}$ Nonetheless, because grade changes implicate various statutory and other rights separate from the right of access, the street use planner must consider the effect of these additional rights. At common law changes in grade did not give rise to a claim for compensation under the "taking" provisions of state constitutions. ${ }^{430}$ This rule led to some harsh results; following suggestions by the courts, ${ }^{431}$ remedial legislation was enacted. Generally legislation took the form of constitutional amendment which added the phrase "or damaged" to the word "taking." 432 In jurisdictions in which this is the law, compensation for change of grade may be obtained if an abutter can establish that the market value of his property has been lowered by the change. ${ }^{433}$

because (1) no claims that reduction in width impaired access, (2) nor could such contention be made because "by the proposed reduction of the street it will have the same width as the majority of streets in city."

Generally the procedure for altering the width of streets is incorporated in a statute. When this is the case, the statutory procedure must be followed. See, e.g., City Improvement Co. v. City of Pittsburgh, $234 \mathrm{~Pa}$. 486, 83 A. 408 (1912). In the absence of a statute the municipality has discretion to decide on the width. See, e.g., Village of Moreauville v. Boyer, 138 La. 1070, 71 So. 187 (1916).

The narrowing of a street may be considered a vacation. See text accompanying notes 436-49 infra. See, e.g., City of Mt. Carmel v. Shaw, 155 Ill. 37, 39 N.E. 584 (1895). On the other hand, a statute delegating power to vacate does not necessarily include the power to narrow. See Dorsch v. Beaumont Glass Co., 74 Ohio St. 208, 78 N.E. 215 (1906).

${ }^{429}$ See, e.g., Callender v. Marsh, 18 Mass. (1 Pick.) 418 (1823); Cook v. State, 176 Misc. 947, 29 N.Y.S.2d 626 (Ct. Cl. 1941), modified, 267 App. Div. 847, 46 N.Y.S.2d 15 (1944) (six feet); O'Connor v. Pittsburgh, $18 \mathrm{~Pa} .187$ (1851) (seventeen feet).

${ }^{430}$ Sauer v. New York, 180 N.Y. 27, 72 N.E. 579 (1904), aff'd, 206 U.S. 536 (1907); Thompson v. Seaboard Airline R.R., 248 N.C. 577, 104 S.E.2d 181 (1958); McCullough v. Village of Campbellsport, 123 Wis. 334, 101 N.W. 709 (1904). See also 2A P. Nichols, supra note $416, \S 6.4441[2]$.

${ }^{431}$ See, e.g., Callender v. Marsh, 18 Mass. (1 Pick.) 418, 434-35 (1823).

${ }^{432}$ E.g., Ill. Const. art. I, $\S 15 ;$ PA. ConsT. art. X, $\S 10$.

${ }^{433}$ See Fox v. City of South Norwalk, 85 Conn. 237, 82 A. 642 (1912); Ressegieu v. City of Sioux City, 94 Iowa 543, 63 N.W. 184 (1895); Cook v. State, 176 Misc. 947, 29 N.Y.S.2d 626 (Ct. Cl. 1941); City of Willimon v. City of Greenville, 243 S.C. 82, 132 S.E.2d 169 (1963). 
As we have seen, the right of access is an ill-defined concept. A change in grade, on the other hand, gives the appearance of being a readily identifiable event. With a wooden jurisprudence a traffic restriction plan might trigger an actionable claim if it is implemented by a grade change, but not if it is done by a barrier fence. Courts might avoid this result either by finding no "change of grade" or by finding no liability for "ordinary and reasonable" changes of grade. ${ }^{434}$ In early cases, "ordinary" changes were those made as a result of the natural formation of the surface or the original mode of construction, while "reasonable" changes were those that increased the public convenience or improved the general appearance of the street. Either of these kinds of change were held noncompensable through the fiction that such changes were contemplated when the municipality first acquired its rights in the street and therefore compensation had already been paid for such future changes. If courts take the wooden though traditional approach, traffic restriction programs implemented by raising street beds to curb levels could easily give rise to compensable claims. To avoid such claims, planners would be well advised by their legal counsel to avoid changing street levels when the goals of a traffic restriction program can be achieved through other physical modifications.

\section{G. Vacation}

A major legal danger in modifying the existing street system is that the changes will be found to constitute vacations. Vacating a street would be counterproductive to a street use plan. In many jurisdictions, vacation requires a particular procedure, and actions that depart from the procedure may be invalidated. ${ }^{\mathbf{4 3 5}}$ Complying with the procedure may obstruct implementation of the street use plan. ${ }^{436}$ If a valid vacation is found, the street may revert to the abutting landowners, possibly leading to the expense of a new taking by eminent domain. ${ }^{437}$ If reversion does

${ }^{434}$ City Council of Montgomery v. Townsend, 80 Ala. 489, 495, 2 So. 155 (1887); City of Pueblo v. Strait, 20 Colo. 13, 36 P. 789 (1894); 2A P. Nichols, supra note 416, § 6.444 1[9]. See also Williams v. State, 34 App. Div. 2d 101, 103, 309 N.Y.S.2d 795, 798 (1970): "Minor adjustments . . . for purposes of repair or improvement [are not a] . . change of grade within the meaning of the statute."

435 See notes $450-60$ infra \& accompanying text.

436 See notes 463-70 infra \& accompanying text.

${ }^{437}$ See notes $471-75$ infra \& accompanying text. 
not occur pursuant to a valid vacation, compensation may nonetheless come due. ${ }^{438}$

\section{Vacation Defined}

Generally a street vacation involves "a substantial and material alteration ... in its character as a street." ${ }^{439}$ Because a traffic restraint program involves "substantial and material" change in street use, a finding of "vacation" is more than a mere possibility. In Wolfe $v$. City of Providence ${ }^{440}$ for instance, the municipal authorities closed part of Promenade Street to through vehicular traffic as part of a plan of rotary traffic. The plan provided for angle parking in the area of Promenade Street blocked off. The court found that "to permanently prohibit . . . the use of the highway at all times to all vehicles ... [was], in effect, [to] decree the abandonment of the street as a vehicular way." 441 To the argument that Promenade Street remained open to the public for pedestrian and parking purposes, the court responded that "except for pedestrians, the public easement of travel on Promenade Street . . . has been banned permanently, and the area has been devoted solely to parking. . . . It is an exclusive use of the street inconsistent with the public easement of passage thereon. Such an inconsistent use is unlawful." ${ }^{42}$ By failing to articulate the nature of the "public easement of passage" the court in Wolfe assumed its conclusion, leaving two broad issues unanswered.

First is the question what uses of the public easement of passage must be exercised to avoid abandonment. The public easement has been repeatedly held to encompass the passage of water mains and gas, sewer, telephone, telegraph, and electric lines. ${ }^{443}$ Surely the court was not implying that all uses must be maintained. To say that removal of gas lines or water mains amounts to an abandonment would be absurd. The court then must have meant that the easement in motor vehicle traffic is essential. But can it be said the easement incorporates a particular mode or modes of transport? Such incorporation is hardly likely when most streets were laid out and used long before

\footnotetext{
${ }^{438}$ See notes $476-79$ infra \& accompanying text.

${ }^{439} 11$ E. McQuillin, supra note 363, 30.178a (3d rev. ed. 1964).

44077 R.I. 192, 74 A.2d 843 (1950), discussed in Comment, supra note 317, at 304-05.

441 Id. at $204,74 \mathrm{~A} .2 \mathrm{~d}$ at 850 .

442 Id. at $206,74 \mathrm{~A} .2 \mathrm{~d}$ at 851 .

${ }^{443}$ See, e.g., In re Grand River Dam Auth., 484 P.2d 505, 510 (Okla. 1971) (use of easement for streets to permit construction of power lines is "a proper use incidental to enjoyment of the public easement").
} 
motor vehicles existed. And even if one were to read the easement narrowly so that it incorporated only the prevailing mode at a particular time one would still have to face the question whether the prevailing mode will be considered the mode in use on the street prior to the change or the mode that will be in use after the legislative body has acted within the scope of its police power. That is to say, is "prevailing mode" solely a function of technology, or can the legislature change the prevailing mode through police power regulation? Such considerations could be pursued ad nauseum. Logic does not require the legal conclusion that vacation be considered a function of the use of streets by motor vehicles.

The second question is what rights and how much discretion are possessed by the municipal corporation in its use and structuring of the easement. Clearly the "public easement of passage" creates no legal right in members of the public as such. Rather the municipality holds the right in trust for the public. ${ }^{444}$ When the Wolfe court says that devoting Promenade Street to pedestrian and parking uses is "unlawful," it is really saying that the municipality has abused this trust. Assuming the municipality is properly exercising its police power in implementing a traffic restriction program, can it at the same time be abusing a public trust? Is the municipality any more a trustee of the streets than of any municipally-owned property? There seems to be no point in drawing a legal distinction between the relationship of the public to the exercise of traditional governmental functions in general and the relationship of the public to the exercise of municipal authority over streets. The Wolfe court escaped this problem by finding the vacation of Promenade Street beyond the authority delegated by Rhode Island to the City of Providence and also violative of due process.

Closing the street to vehicular traffic is not necessarily considered a vacation. In Calumet Federal Savings and Loan Association v. City of Chicago, ${ }^{445}$ Torrance Avenue was closed at its intersections with 95 th and 97 th Streets by the erection of seven-inch high concrete curbs. The trial court found that the construction of the curbs amounted to a vacation. The Appellate Court of

${ }^{444}$ Wolfe v. City of Providence, 77 R.I. 192, 202-03, 74 A.2d 843, 849 (1950). See Nielson v. City of Chicago, 330 Ill. 301, 161 N.E. 768 (1928); Lohr v. Metropolitan Elevated R.R., 104 N.Y. 268, 10 N.E. 528 (1887); Hamilton G. \& C. Traction Co. v. Parish, 67 Ohio St. 181, 65 N.E. 1011 (1902).

445306 Ill. App. 524, 29 N.E.2d 292 (1940). 
Illinois reversed, indicating that a "vacation of a public street involves its complete abandonment for street purposes . . ."446 Because vehicles continued to have access to Torrance via 96th Street it was obvious to the court that there had been no vacation. The meaning of vacation was subsequently refined in Chicago National Bank v. City of Chicago Heights, ${ }^{447}$ which involved an ordinance closing a street to all vehicular traffic. The court found that this did not amount to a vacation either, because it was not a "complete abandonment." 448 Unlike the court in Wolfe, which found that limiting a street to pedestrian use amounted to reducing it to a "mere footway," 449 the Chicago National Bank court recognized pedestrian use as a legitimate street use. Considering that any rational program of traffic restriction would provide for access for emergency vehicles, a finding of vacation will generally turn on this question of whether or not the court considers pedestrian use a legitimate street use. Given the temper of the times and the ready availability of data justifying exercise of the police power, it is more likely than not that courts would not find a vacation in a plan of traffic restriction that included limiting a street to pedestrian use.

\section{Procedural Problems}

A finding of a vacation would raise barriers more substantial than would claims for compensation that may arise with regard to taking or damage of the right of access, although the issue of compensation to abutters would also arise. ${ }^{450}$ The procedure for

${ }^{446} I d$. at 529,29 N.E.2d at 294.

44714 Ill. 2d 135, 150 N.E.2d 827 (1958).

Cf. CAL. STS. \& H'ways Code $\$ 8306$ (West 1969), which provides that " '[v]acation' includes the abandonment of public street easements and the closing of streets to public use."

Whether a vacation occurs depends in part on the nature of the easement. To the extent that the street continues to be used consistently with the easement there has been no vacation. See In re Grand River Dam Auth., 484 P.2d 505 (Okla. 1971).

"Vacation" can occur without a "closing." In McKinney v. Rowland, 197 Iowa 180, 186, 197 N.W. 88, 90 (1924), for example, the court held that vacation is "simply a disclaimer . . . to assume further jurisdiction in the supervision of the streets in controversy, and removes the burden of taxation incidental in keeping said streets in use or repair." In Bigelow v. Ballerino, 111 Cal. 559, 565, 44 P. 307, 309 (1896), on the other hand, the court noted that a vacation "involves something more than a mere constructive closing . . . It involves a physical closing as well . . . See, e.g., Wis. Stat. AnN. § 66.298 (Supp. 1975) (designation of street as pedestrian mall "shall not constitute a . . . vacation of such street ....").

${ }^{448} 14$ Ill. $2 \mathrm{~d}$ at 142,150 N.E.2d at 830 .

44977 R.I. at $204,74 \mathrm{~A} .2 \mathrm{~d}$ at 850.

${ }^{450}$ See notes $476-79$ infra \& accompanying text. 
vacating a public way is the subject of statute in virtually every jurisdiction. The prevailing rule is that the statutory procedure must be strictly adhered to or the proposed vacation will be enjoined. ${ }^{451}$ Extreme examples of the application of this rule are cases in which vacations have been struck down when authorized by resolution instead of ordinance, ${ }^{452}$ or when the statute required five disinterested "freeholders" to assess damages and the council selected five "householders." ${ }_{453}$ Although courts occasionally find deviations from the statutory formula not substantial, ${ }^{454}$ a part of a traffic restriction program found to be a vacation will generally fail unless strict compliance with the applicable statute is manifested.

Vacation statutes generally provide for local legislative bodies to order a vacation. ${ }^{455}$ Because the decision to vacate is a legislative one, it generally is not the subject of judicial review. ${ }^{456}$ This general proposition is subject to the conventional exceptions of fraud, arbitrariness, collusion, and "clear abuse of power."457 In addition, statutes authorizing vacations generally

${ }^{451}$ See, e.g., Mahan v. Rockport, 287 Mass. 34, 190 N.E. 810 (1934); Hughes v. Bingham, 135 N.Y. 347, 32 N.E. 78 (1892); Shapera v. Allegheny County, 344 Pa. 473, 25 A.2d 566 (1941); In re Mackrill's Addition, 85 S.D. 196, 200, 179 N.W.2d 268, 270 (1970). See also Messinger v. Cincinnati, 36 Ohio App. 337, 173 N.E. 260 (1930); 11 E. McQuilin, supra note 363 , $\$ 30.185$.

Why strict compliance with this type of statute should be required is none too clear. One court has suggested that the "vacation of highways is not favored." McHenry v. Foutty, 223 Ind. 335, 339, 60 N.E.2d 781, 782 (1945).

${ }_{452}$ Mitchener v. City of Okmulgee, 100 Okla. 98, 228 P. 159 (1924).

${ }^{453}$ Jones v. City of Aurora, 97 Neb. 825, 151 N.W. 958 (1915). (1902).

${ }^{454}$ Village of Bellevue v. Bellevue Improvement Co., 65 Neb. 52, 90 N.W. 1002

455 Occasionally the vacation power is delegated to the courts. OHIO REv. Code ANN. § 723.09 (Page 1954). See, e.g., In re Hull, 163 Minn. 439, 204 N.W. 534 (1925); Duenke v. County of St. Louis, 358 Mo. 91, 213 S.W.2d 492 (1948). See also Dorsch v. Beaumont Glass Co., 74 Ohio St. 208, 78 N.E. 215 (1906).

${ }^{456}$ See, e.g., Beals v. City of Los Angeles, 23 Cal. 2d 381, 144 P.2d 839 (1943); Blanding v. City of Las Vegas, 52 Nev. 52, 280 P. 644 (1929); Banchero v. City Council, 2 Wash. App. 519, 468 P.2d 724 (Ct. App. 1970); cases collected in 3 J. Dillon, Municipal Corporations 1837 (5th ed. 1911). See also Ill. Ann. Stats., ch. 24, § 11-91-1 (SmithHurd 1962): "The determination of the corporate authorities that the nature and extent of the public use or public interest to be subserved is such as to warrant the vacation of any street or alley, or part thereof, is conclusive ...."

${ }^{457}$ See, e.g., People v. Gity of Mt. Vernon, 404 Ill. 58, 88 N.E.2d 45 (1949); Smith v. Village of Wintersville, 26 Ohio Op. 2d 40, 187 N.E.2d 511 (Ct. App. 1962); City of Greenville v. Bozeman, 254 S.C. 306, 315, 175 S.E.2d 211, 215 (1970); Sweetwater Memorial Park, Inc. v. City of Sweetwater, 213 Tenn. 1, 4, 372 S.W.2d 168, 169 (1963); Banchero v. City Council, 2 Wash. App. 519, 525, 468 P.2d 724, 729 (Ct. App. 1970); Clifford v. City of Cheyenne, 487 P.2d 1325 (Wyo. 1971).

Generally a legislative body will have a strong case when its action is predicated, at least in part, on the recommendations of an expert body or consultant. In Hoskins v. City 
define the criteria for judicial review. These grounds are usually rather broad, for instance, that the "public interest will be subserved." 458 This admonition may be read literally so that "the advantage to the public must come from the vacation itself and not the use to which the property will be put in the future."459 Municipal decisions to close streets have been overruled by courts because they failed to comply with the broad "public interest" language. ${ }^{460}$ The archetypal case is a vacation "for the sole purpose of benefiting an abutting property owner."461 Courts rarely find such exclusive benefit, however. ${ }^{462}$ The statutory criteria are thus unlikely to pose difficulties for traffic restriction plans.

A more serious difficulty presented by vacation is that some statutes provide for participation of abutting owners in the deci-

of Kirkland, 7 Wash. App. 957, 503 P.2d 1117 (Ct. App. 1972), the court went further and found that even though the City Council was "free to evaluate the force and effect of the commission's recommendation. Such disagreement alone does not amount to bad faith ...." Id. at 964, 503 P.2d at 1122 .

${ }^{458}$ Ill. AnN. Stat. ch. 24, § 11-91-1 (Smith-Hurd 1962). See, e.g., Cal. Sts. \& H'ways CoDE $\$ 8323$ (West 1969) ("[If streets are] unnecessary for present or prospective public purposes"); OHIo Rev. CODE ANN. $\$ 723.05$ (Page 1954) (good cause .. . and not detrimental to the general interest"); PA. STAT. ANN. tit. 53, § 1672 (1974) ("necessary"); Wis. Stat. AnN. $\S 66.297(1)$ (Supp. 1975) (if "the public interest requires . . . or [the streets are] of no public utility"); NEw YORK CITY ADMIN. CODE § E15-3.0(a) (Supp. 1974) (vacation permitted to "further the health safety, pedestrian or vehicular circulation, housing, economic development or general welfare of the city").

459 Clifford v. City of Cheyenne, 487 P.2d 1325, 1330 (Wyo. 1971) (citing Webb v. City of San Rafael, 95 Cal. App. 733, 273 P. 138 (Dist. Ct. App. 1928).

${ }^{460}$ See, e.g., Yarrow First Associates v. Town of Clyde Hill, 66 Wash. 2d 371, 374, 403 P.2d 49, 52 (1965) (vacation to prevent use of street by nonresidents not "based upon some element of "public use" ").

${ }^{461}$ Stahl Soap Corp. v. City of New York, 5 N.Y.2d 200, 205, 156 N.E.2d 443, 445, 182 N.Y.S.2d 808, 811 (1959); City of Greenville v. Bozeman, 254 S.C. 306, 315-16, 175 S.E.2d 211, 215 (1970). See Hudson v. American Oil Co., 152 F. Supp. 757 (E.D. Va. 1957), affd, 253 F.2d 27 (4th Cir. 1958); Banchero v. City Council, 2 Wash. App. 519, 523,468 P.2d 724, 728 (1970) (review the legislative determination "[o]nly where there is no possible benefit to the public"); Clifford v. City of Cheyenne, 487 P.2d 1325 (Wyo. 1971). The Banchero test was applied in Hoskins v. City of Kirkland, 7 Wash. App. 957, 963-64, 503 P.2d 1117, 1122 (1972).

${ }^{462}$ In City of Greenville v. Bozeman, 254 S.C. 306, 175 S.E.2d 211 (1970), for example, the city and a bank entered into an agreement to redevelop a three-block area of the center city. The city was to construct a parking facility for 700 vehicles and the bank was to construct a high-rise bank office building. To accomplish this goal several streets had to be vacated. The court responded to the allegation that the benefit accrued solely to the bank by noting that while the bank "instigated" the vacation, the redevelopment project "is a joint venture, so to speak, between the City of Greenville and the Bank which will inure to the benefit of both and by benefitting the City it will benefit its citizens." Id. at 316, 175 S.E.2d at 215. Similarly, in Clifford v. City of Cheyenne, 487 P.2d 1325 (Wyo. 1971), a shopping center developer who owned property on both sides of a street proposed the vacation of that portion of the street. The vacation would enable the developer to enlarge his parking lot. The vacation would also be a step in a transac- 
sion to vacate. ${ }^{463}$ Some statutes require a hearing as a prerequisite to vacation. ${ }^{464}$ When vacation is a judicial proceeding, abutters must be joined as defendants. ${ }^{465}$ The significance of these requirements is that should a plan be found to constitute a vacation, the statutory process will provide a convenient focal point for the organization of forces opposed to the street use plan.

At least initially, street closings for pedestrianization have been opposed by abutting merchants. In New York City, for instance, the Fifth Avenue Association represented merchants who owned shops on Madison Avenue in a successful suit to prevent implementation of a plan to ban private vehicles and taxis from Madison Avenue. ${ }^{466}$ The merchants apparently brought the suit because they feared their customers would take their trade to establishments more accessible by taxi or auto. ${ }^{467}$ Mumford found similar attitudes among the merchants of Coventry and Rotterdam, where there was significant opposition to restricting traffic on shopping streets for fear of loss of the "carriage trade." ${ }^{468}$ And at a symposium, sponsored by the Organisation for Economic Cooperation and Development, where the experience with "car-free zones and pedestrian streets in Bremen, Cologne, Copenhagen, Landskrona, Leeds, Marseille,

tion for the elimination of a "five-legged intersection," something the town had long planned. And in exchange for the vacation the city received an alternate right of way and other benefits which saved the city $\$ 15,000$ to $\$ 20,000$.

Despite the manifest private benefit in these cases, the courts were reluctant to find that the benefits were exclusively private. Instead they seem inclined to follow the path of development of the "public purpose" requirement in eminent domain.

${ }^{463}$ E.g., Mont. Rev. Codes Ann. \& 11-3310 (1947), discussed in Kemmer v. City of Bozeman, 158 Mont. 354, 492 P.2d 211 (1971).

${ }^{464}$ See, e.g., WIs. STat. ANN. $§ 66.297(2)$ (Supp. 1975). See generally N.Y. Times, Oct. $28,1973, \S 4$, at 10 , col. 3 .

465 Ky. Rev. STar. Anv. §§ 93.360, 94.360 (1970). See Riedling v. Harrod, 298 Ky. 232, 182 S.W.2d 770 (1944).

${ }^{466}$ Fifth Ave. Ass'n, Inc. v. Lindsay, 73 Misc. 2d 111, 341 N.Y.S. 473 (Sup. Ct.), aff'd, 344 N.Y.S.2d 633 (App. Div. 1973).

${ }^{467}$ N.Y. Times, Oct. $28,1973, \S 4$, at 10 , col. 3. But see Crampton v. City of Royal Oak, 362 Mich. 503, 529, 108 N.W.2d 16, 28 (1961) (dissenting opinion).

${ }^{468}$ L. MUMForD, supra note 124 , at $44-45$. Cautious experimentation may be the way to alleviate these fears. In Manhattan, a "five-block stretch of Nassau Street,-a narrow thoroughfare that winds through the financial district ... has been closed to vehicular traffic on weekdays between 11:00 A.M. and 2:00 P.M. since the spring of 1969. The closing has met with almost unanimous approval of the merchants . . ." N.Y. Times, Nov. 4, 1973, at 46, col. 1. A proposal to make the closing permanent and complete has "won approval" of the merchants to the extent that they were willing to contribute $\$ 5000$ of the $\$ 20,000$ fee for a study of the feasibility of the proposal. A similar project for Fulton St. in Brooklyn has also met with a favorable response from the abutting merchants. Id. 
Minneapolis, New York, Paris, Reading, Rome, Stockholm and Tokyo were discussed in detail," observations showed that local shopkeepers were on the whole initially skeptic [sic]."469

The significance of this opposition may be quickly reduced as merchants become increasingly familiar with traffic restriction programs. Indeed, in New York, the Fifth Avenue Association later repented, testifying in hearings in favor of the Madison Avenue mall. Groups representing the taxi industry, however, managed to sustain the opposition to the project. While the projects discussed at the OECD symposium aroused initial opposition, merchants generally acquiesced within a few months. Merchants in many cities have discovered that traffic restriction can lead to more business for shops abutting the affected street. $^{470}$

\section{Problems of Reversion and Compensation}

If a vacation occurs, the street usually reverts in fee simple to the abutting landowners. This result derives from the general rule in the United States that the abutting landowner will be held

${ }^{469}$ OECD, supra note 126 , at 77.

470 As early as the 1920's all vehicular traffic was banned from Limbecker Strasse in Essen. The move was so popular that business volume in relation to street area was at that time among the highest in Europe. See HUD BRIEF, supra note 80, at 14. See also Streets For PeOple, supra note 288, at 10.

More recently pedestrianization has spread to other streets in Essen with equally happy results. Shortly after Tokyo banned vehicular traffic from 122 of the busiest downtown streets, affected merchants reported retail sales up 50\%. Von Eckardt, People, Yes; Cars, No, SAT. Rev., Oct. 3, 1970, at 62 . In a survey of 574 shops, $21 \%$ reported an increase in sales, $60 \%$ no change, and $19 \%$ a decrease. Of the merchants interviewed, 74\% favored the scheme. See HUD BRIEF, supra, at 4 . After three and a half years of experience with a traffic-free street, London street merchants in Norwich are enthusiastic about the plan. See Von Eckardt, supra, at 62. In several German cities businessmen in streets adjacent to traffic-free streets asked to have their streets included in the trafficfree zone. See Kühnemann \& Witherspoon, supra note 288 , at 67 . Similarly several German cities reported increased demand for floor space in the part of department stores and banks near traffic-free areas. See id. 68.

The most recent success in the application of this policy has been the closing of Oxford Street, the "biggest shopping center in England," to all traffic except taxis and buses. Sidewalks were widened, trees planted, and benches installed. In a survey taken in May, 1972, six months after the plan went into operation, $85 \%$ of area residents were in favor of the plan and, more important, area shopkeepers reversed their role from opposition to support. N.Y. Times, June 29,1973 , at 6 , col. 1 . A later survey published in December, 1973, indicated that "shop managers in Oxford Street [considered] the scheme . . . a success for the majority of shops." GREATER London Council INTELLIGENCE UNIT Q. BULL., Dec., 1973, at 18.

One of the largest projects of this kind in the United States is the Nicollet Mall in Minneapolis. Eight blocks of Nicollet Avenue were closed to private traffic and the street resurfaced to provide for a 24-foot curving "transitway" for buses and sidewalks of up to 36 feet in width paralleling it. Retail business on Nicollet Avenue has increased 14\% since 
to own the fee in the public way in front of his property to the center thereof, subject to the public easement. ${ }^{471}$ Historically, most streets came into being as a result of dedications or takings; the presumption is that the dedication or taking was limited to the public's need at the time, conveying an easement of passage rather than a fee. ${ }^{472}$ The fee remained with the abutting landowner. Occasionally, the fee to the streets is held by the municipality. In some cases, the title to the streets never leaves the sovereign which granted fees to abutting properties. In New York, for example, the grants of the Dutch Government have been held to have exempted title to the beds of public ways from the grants. ${ }^{473}$ Similarly, when streets have originated through platting statutes which vested title to the street in the municipality, vacation would leave the fee in the municipality. ${ }^{474}$ Finally,

the mall opened and "the mall has generated some $\$ 49$ million in new construction and rehabilitation." It should be noted that data are difficult to come by because of a natural reluctance of businessmen to give out sales information. See Kühnemann \& Witherspoon, supra, at 67.

${ }^{471}$ Skeritt Invest. Co. v. City of Englewood, 79 Colo. 645, 248 P. 6 (1926); Town of Hustisford v. Knuth, 190 Wis. 495, 209 N.W. 687 (1926); IDAHo CODE § 50-311 (1967); Ill. Ann. Stat. ch. 24, § 11-91-2 (Smith-Hurd 1962); Kan. STat. ANn. § 12-506 (1964); OкLA. Stat. AnN. tit. 11, §§659, 1004 (1959).

${ }^{472}$ A common law dedication created an easement. See Neil v. Independent Realty Co., 317 Mo. 1235, 298 S.W. 363 (1927); Waterloo Condensed Milk Co. v. Voges, 316 Ill. 477,147 N.E. 373 (1925). Statutory dedications vary in effect depending on the statute. In Illinois, for example, they create a determinable fee. See St. Clair County Housing Auth. v. Southwestern Bell Tel. Co., 387 Ill. 180, 56 N.E.2d 357 (1944).

On taking an easement only, see, e.g., Northern Ind. Gas \& Elec. Co. v. Merchants Improvement Ass'n, 87 Ind. App. 74, 160 N.E. 50 (1928).

${ }^{473}$ See DeWitt v. Elmira Tranfer Ry., 134 N.Y. 495, 32 N.E. 42 (1892); Cohen, Abandonment of Highways and the Effects Upon the Rights of the Public and Property Owners, 23 N.Y. State B. Ass'n Bull. 57, 58 (1951). See also Pooler v. Sammet, 130 App. Div. 650 , 115 N.Y.S. 578 (1909).

A possibility is that the fee in the street was dedicated to the city for use as a street and that upon its abandonment, it will revert to the heirs of the dedicator. See Neil v. Independent Realty Co., 317 Mo. 1235, 298 S.W. 363 (1927). When the abutting owner is not the successor in interest to the original owner, the fee may revert to the original owner and not the abutter. See Oberhelman v. Allen, 7 Ohio App. 251 (1915). A theory of reversion to the abutting owners following a vacation is the doctrine of accretion. The theory is that although the public gives up its easement upon vacation, the private easements of the abutting owners remain. To preserve the easements, or, more correctly, the right of ingress and egress, it is necessary that the vacated street become part of the abutting lots. See Hamilton G. \& C. Traction Co. v. Parish, 67 Ohio St. 181, 190, 65 N.E. 1011,1013 (1902).

The assumption implicit in the common law rule that each of the abutting owners had contributed equally to the street is also rebuttable. See, e.g., Watrous v. Southworth, 5 Conn. 305 (1824).

${ }^{474}$ See, e.g., Town of Kenwood Park v. Leonard, 177 Iowa 337, 158 N.W. 655 (1916) (dictum); Lindsay v. City of Omaha, 30 Neb. 512, 46 N.W. 627 (1890). But see Olin v. Denver \& R.G.R. Co., 25 Colo. 177, 53 P. 454 (1898); Prall v. Burckhartt, 299 Ill. 19, 132 N.E. 280 (1921); Sowadzki v. Salt Lake County, 36 Utah 127, 104 P. 111 (1909). 
the holder of the fee to streets whose origin lay in statutory dedication may be determined by the statute.

Thus a critical factor to be considered in implementing a traffic restriction plan is the history of the streets under examination. Given a choice between the vacation of a street wherein the fee clearly lies with the municipality as opposed to one whose history is unclear, the former should be the site of the vacation. The distinction, probably imperceptible to the non-lawyer, could involve substantial sums of money. If the fee to the street reverts to the abutters, the planners may lose control of it and may be forced to buy it back via eminent domain in order to implement their traffic restriction plan. 475

Compensating abutters of a vacated street may also become an issue. In some cases the standard is provided for by statute. ${ }^{476}$ Where it is not, the better and more logical rule would deny compensation on the ground that a vacation is not a taking. Vacation generally involves the removal of the public easement from the fee of the abutting owners and a restoration to them of their land "freed from the servitude of the public way."477 The vacation does not affect abutters' rights to access, light, and air, which remain in full force and effect. ${ }^{478}$ The better rule does

${ }^{475} \mathrm{~A}$ less costly alternative which might maintain the vacated street as open space is a setback requirement in the zoning code.

${ }^{476}$ See, e.g., Nielson v. City of Chicago, 330 III. 301, 161 N.E. 768 (1928); In re Gillen Place, 304 N.Y. 215, 106 N.E.2d 897 (1952); In re Melon St., 182 Pa. 397, 38 A. 482 (1897). The latter case was used to interpret PA. Stat. ANN. tit. 26, $\$ 1-613$ (Supp. 1975) to create a right of compensation for vacation in Condemnation Case, $430 \mathrm{~Pa}$. 273, 242 A.2d 432 (1968), cert. denied, 393 U.S. 1049 (1969). See also Hedrick v. City of Harrisburg, 278 Pa. 274, 122 A. 281 (1923).

${ }_{477}$ Wetherill v. Pennsylvania R.R., 195 Pa. 156, 160, 45 A. 658, 660 (1900). The laws of Illinois go further and provide for the abutting landowners to compensate the municipal authorities in an amount "equal to the benefits which will accrue to them by reason of the vacation." 24 ILl. ANN. STAt. § 11-91-1 (Smith-Hurd 1962). See also Harman v. City \& County of San Francisco, 7 Cal. 3d 150, 496 P.2d 1248, 101 Cal. Rptr. 880 (1972).

478 See, e.g., Harman v. City \& County of San Francisco, 7 Cal. 3d 150, 167, 496 P.2d 1248, 1259, 101 Cal. Rptr. 880, 891 (1972): "[P]rivate easement of ingress and egress . . . continues even though the city by vacation terminates the public right of access to the street." See Paul v. Wissalohican Camp Co., 104 Ohio App. 253, 257, 148 N.E.2d 248, 250 (1957): "[A] private easement in public highway is already in existence when the highway is vacated, and continues if there is a reasonable need for it." See Central Trust Co. v. Hennen, 90 F. 593 (6th Cir. 1898); In re Nichols, 54 N.Y. 62 (1873); Plitt v. Cox, 43 Pa. 486 (1862). The authorities may also reserve easements in vacated streets. See, e.g., CAL STS. \& H'wAys CODE $\$ 8330$ (West 1969) (city may reserve and except from vacation easements for storm drains, sewers, pipelines, wires, telegraphic and telephone lines). Contra, Libertini v. Schroeder, 149 Md. 484, 132 A. 64 (1926); Schweitzer v. Adami, 110 N.J. Eq. 193, 159 A. 529 (Ch. 1932), aff'd, 113 N.J. Eq. 46, 166 A. 124 (Ct. Err. \& App. 1933). A street closing under the New York Street Closing Act of 1895 terminated both public and private easements in the street. Barber v. Woolf, 216 N.Y. 7, 109 N.E. 868 (1915); Johnson \& Co. v. Cox, 196 N.Y. 110, 89 N.E. 454 (1909). 
not, however, appear to be the general rule, which finds vacation a compensable injury to abutters. ${ }^{479}$

\section{Special Benefits}

The financial benefits that may flow from a traffic restriction program to abutters and the continued deterioration of the central business district in the absence of such programs should gradually reverse merchant opposition. Financial benefits will also have a positive effect. ${ }^{480}$ To the extent that a restriction program gives rise to a claim for compensation by an abutter, either because of taking or damage to the right of access or as the result of vacation, the claim may be offset by the "special benefits" conferred on the abutter by the program.

In Richley $v$. Bowling ${ }^{481}$ the court defined special benefits as those that "accrue directly and solely to the owner of the lands, from which the right is taken," as distinguished from general benefits, which are "such as accrue to community, or the vicinity at large." 482 In Richley, the state took a strip of defendant's land for a limited access highway. An access road that provided a means of entering and leaving the new highway was constructed along the eastern boundary of defendant's property. The state offered to show that an oil company was willing to purchase a segment of defendant's property composing the "first off the ramp" location for a price that would fully offset the damages imposed by the taking. The testimony was not admitted. This ruling was upheld on appeal on the ground that the access road created a "general" as opposed to a "special" benefit.

The increase in value was, the court said, due to "the anticipated increase in traffic and the semi-monopolistic condition of exit roads on a limited access highway." This was not a direct effect but an indirect one. A direct effect would be a change that improved the drainage, elevation, topography, or fertility of the land itself. In addition, the benefits were not conferred "solely" on the subject property. For example, "[e]very exit on the

${ }^{479}$ See 11 E. McQuillin, supra note 363, § 30.188.

${ }^{480}$ A classic example of a special benefit that may be conferred upon abutting land by a restriction program is the conversion of Maiden Lane in San Francisco from "an odd two-block-long, narrow, back-door alley" into "one of the finest shopping streets in America." Jacobs, Downtown is for People, in Editors of Fortune, Exploding Metropolis 161-62 (1958).

48134 Ohio App. 2d 200, 299 N.E.2d 288 (1972).

${ }^{482} I d$. at 202-03, 299 N.E.2d at 291 (quoting Little Miami R.R. v. Collett, 6 Ohio St. $182,186(1856))$. 
limited access road experiences the same change to a situs of a preferred commercial location ...."483 Moreover, the access road "benefited not only the defendants' land, but all lands bordering upon it on both sides ...."484 The court concluded that the gain in commercial value was not "a special benefit with some value to be deducted from the damages then ascertained." 485

It is worth exploring the complexities of the "special benefits" rule, ${ }^{486}$ because the rule suggests a virtually cost-free solution to the land use problems of a traffic restriction plan. The United States Constitution does not prohibit deducting benefits from the required compensation. ${ }^{487}$ The jurisdictions are split on whether, absent statutory authority authorizing deduction, such a deduction can be made. ${ }^{488}$ In some states nondeductibility has been incorporated in statutes ${ }^{489}$ or the constitution. ${ }^{490}$ Some jurisdictions, including New York and Illinois, ${ }^{491}$ hold that both general and special benefits may be deducted. The earliest cases made no distinction between general and special benefits; ${ }^{492}$ the refinements were made in the interest of "fairness." If all sur-

${ }^{483}$ Id. at 204, 299 N.E.2d at 292.

${ }^{484} I d$. at 205, 299 N.E.2d at 292.

${ }^{485} I d$. The court, however, allowed consideration of the value to defendant of the road as mitigation of specific damages that would have been awarded had the road not been built. Without the road, there would have been no means of access to the property. Hence the road could be considered to mitigate damage to the right of access. 486 "Upon this subject there is a great diversity of opinion and more rules, different from and inconsistent with each other, have been laid down than upon any other point in the law of eminent domain." 3 P. Nichols, supra note 416 , \$ 8.62.

487 Bauman v. Ross, 167 U.S. 548 (1897).

${ }^{488}$ Compare State Highway Comm'n v. Breisacher, 231 Mich. 317, 204 N.W. 112 (1925) and Harrold v. Good Roads Comm., 182 N.C. 577, 109 S.E. 625 (1921), with State v. Botluck, 57 Del. 362, 200 A.2d 424 (1964).

489 See, e.g., Mrss. Code ANN. $§ 11-27-21$ (1972).

490 Hamer v. State Highway Comm'n, 250 Iowa 1228, 98 N.W.2d 746 (1959); Finley v. Board of County Comm'rs., 291 P.2d 333 (Okla. 1955). Section 19 of Article I of the Ohio Constitution provides, inter alia, that "such compensation shall be assessed by a jury, without deduction for benefits to any property of the owner." See Richley v. Bowling, 34 Ohio App. 2d 200, 202, 299 N.E.2d 288, 291 (1972).

491 Brand v. State, 46 Misc. 2d 645, 260 N.Y.S.2d 239 (Ct. Cl. 1965), modified on other grounds, 26 App. Div. 2d 747, 272 N.Y.S.2d 210 (1966); In re Exterior St., 285 N.Y. 455, 35 N.E.2d 39 (1941); Department of Pub. Works \& Bldgs. v. Keck, 330 Ill. 39, 161 N.E. 55 (1928); Sanitary Dist. v. Boening, 267 Ill. 118, 107 N.E. 810 (1915). New York allows general and special benefits to "be set off against damages to the remaining part, but not against the value of the part taken ...." Chiesa v. State, 36 N.Y.2d 21, 23, 324 N.E.2d 329, 331,364 N.Y.S.2d 848, 849 (1974).

Alabama statutes provide for setoff of "the value of enhancement to the remaining lands" but not of incidental benefits. Ala. Code tit. 19, $\$ 14$ (1958). See, e.g., State v. Goodwyn, 272 Ala. 618, 133 So. 2d 375 (1961). See generally cases collected in 3 P. Nichols, supra note 416 , § 8.6205, at 86 n.60.

${ }^{492}$ See, e.g., Commonwealth v. Justices, 9 Mass. 388 (1812). 
rounding landowners shared in the general benefits, it was argued, it would be unfair to require payment only from the owner whose property was taken. ${ }^{493}$ Moreover, general benefits were considered merely conjectural..$^{494}$

The label conjectural could apply equally to special and general benefits and so really does not support the distinction. But the fairness argument does support excluding general benefits from a setoff. Otherwise the burden of public improvements would be arbitrarily assigned to those whose property was taken. On the other hand, special benefits should constitute some kind of a setoff. It would be wrong to compensate a property owner for a "loss" when he is actually better off financially after the "taking or damage" than before, and when his position is improved to a much greater degree than that of his neighbors. A rule must be formulated to identify these situations.

The unique or sole benefit rule is exemplified by State ex. rel. Department of Highways v. McPherson, ${ }^{495}$ in which the State took 115.69 acres of defendant's land for the construction of an interstate highway. The value of the land was found to be $\$ 455$ per acre. On the other hand, the defendant sold dirt removed from 48.5 acres to the road contractor at an average price of $\$ 1200$ per acre. The Louisiana Court of Appeal found that the owner was able to sell his dirt at a sum twice his own estimate of market value because of the highway project, and that the difference between value as found and the price for the dirt was therefore a "special benefit" to him. The Louisiana Supreme Court reversed because it found that six other surrounding landowners (whose land had not been taken) also sold dirt for the highway construction; therefore "the benefit [was] not special to McPherson. It [was] instead general to those located near the right of way who [had] the type of soil desired and who [were] willing to sell." 496 The court indicated that to decide otherwise would deny justice to McPherson. ${ }^{497}$

${ }^{493}$ See Chiesa v. State, 36 N.Y.2d 21, 324 N.E.2d 329, 364 N.Y.S.2d 848 (1974); Meacham v. Fitchburg R.R., 58 Mass. (4 Cush.) 291 (1849).

${ }^{494}$ See, e.g., State v. Hudson County Freeholders, 55 N.J.L. 88, 25 A. 322 (Sup. Ct. 1892), $c f$. Chiesa v. State, 36 N.Y.2d 21, 25, 324 N.E.2d 329, 332-33, 364 N.Y.S.2d 848, 851 (1974).

${ }_{495} 241$ So. 2d 543 (La. Cir. Ct. 1970), modified, 261 La. 116, 259 So. 2 d 33 (1972). 496261 La. at 136,259 So. $2 d$ at 40.

497 The court also indicated that the dirt sales resulted more from the peculiar suitability of the dirt for roadbed than from the location of the construction. Thus the sale was an "advantage to the owner, not the property." Id. at 137, 259 So. $2 \mathrm{~d}$ at 40. 
In addition to "uniqueness," the Richley court and others have found a limitation on special benefits in "directness." In effect the courts are using a proximate cause test, evaluating the remoteness of the physical improvement from the benefit received. ${ }^{498} \mathrm{~A}$ physical change in the land that improves drainage is a relatively direct benefit and the Richley court indicated that it would find such a benefit "special." In Farrell v. State Highway Board, ${ }^{499}$ the court eschewed the uniqueness test which seemed to treat the government's interest so harshly in the Richley context. Relying solely on "directness," the Farrell court nonetheless reached a "general benefit" conclusion on facts similar to those in Richley. An increase in traffic at an exit, the court held, is naturally an indirect effect of a limited access highway program and thus can never be a special benefit. ${ }^{500}$

This view has a certain appeal. If a diversion of traffic resulting in an erosion of property values is damnum absque injuria, ${ }^{501}$ a nice corollary is found in the rule that an attraction

${ }^{498}$ A recent case whose facts parallel a typical traffic restriction situation was resolved on a remoteness theory. United Cal. Bank v. State ex rel. Dep't of Pub. Works, 1 Cal. App. 3d 1, 81 Cal. Rptr. 405 (Dist. Ct. App. 1969), involved the creation of a downtown shopping mall in the City of Pomona. As part of the plan First Street was closed and turned into a parking area. Several political entities were involved in the project. The State Department of Highways was responsible for closing First Street and turning it over to "a parking district" which would "convert it to parking purposes." The State attempted to introduce evidence showing that the conversion of First Street into a parking area was a special benefit to the defendant. Section 1248(3) of the Code of Civil Procedure limited special benefits "to those arising from '. . the construction of the improvement proposed. .. ." Id. at 9,81 Cal. Rptr. at 412 . While not denying that the conversion could in fact amount to a special benefit, the court found that the State's role was limited to closing First Street. "[T] he development of it thereafter for parking use was no part of its work; hence, the development could not constitute a special benefit." Id. The court's interpretation seems strained at best: The special benefit rule is applied to offset valid claims for compensation, and such claims do not arise from "the construction of the improvement" but from some "taking or damage" prior to the commencement of construction. To consider the act giving rise to the claim for compensation and the subsequent act conferring the special benefit as two transactions is not demanded by either the law or the facts. The most plausible explanation is that the court seized upon this difference because of a belief that the benefit was not the creation of parking space but the increased patronage that might flow from the new parking facility.

499123 Vt. 453, 194 A.2d 410 (1963).

${ }^{500}$ But see State ex rel. Dep't of Highways v. Hayes, 150 So. 2d 667 (La. Cir. Ct. App. 1963). The state took part of defendant's land for a new highway. The portion taken had abutted a dedicated but ungraded street. The tract was used for a new highway, changing defendant's land use from industrial to commercial and more than tripling the value of defendant's land from $\$ 4,800$ to $\$ 16,050$. The court, with remarkably little reasoning, had no difficulty in finding a special benefit to the defendant. Whether there were other beneficiaries similarly situated was not discussed by the court.

${ }^{501}$ See note 396 supra. 
of traffic will not be found to be a special benefit. ${ }^{502}$ The attraction of symmetry may be counterbalanced, however, by a social policy that favors individual absorption of diversion losses but a sharing of the gains of attraction. The Wisconsin Supreme Court has adopted a "highest and best use" test which allows the condemnor to recoup the compensation he otherwise would have to pay. ${ }^{503}$ The court found that an upward shift in use from agricultural to commercial, not an increase in the commercial value of land, could be used by the state as a setoff.

We can posit three landowners abutting a new access road. The first, $A$, owns the property directly adjacent to the new limited access highway and the market value of his remaining land is found to have increased from $\$ 10$ to $\$ 20$ per acre. The next landowner, $B$, although abutting the access road, is separated from the highway by $A$ 's land. The value of $B$ 's remaining land is found to have increased from $\$ 10$ to $\$ 18$ per acre. $C$ 's land is next in line away from the highway and his remaining land is found to have increased from $\$ 10$ to $\$ 15$ per acre. The value of land generally is found to have increased from $\$ 10$ to $\$ 12$ per acre as a result of the highway construction.

We should be reluctant, notwithstanding the "special benefits" rule, to reward them doubly by giving compensation. $A, B$, and $C$ all have enjoyed great benefits. But to what extent should their compensation be curtailed? The simplest view would be the difference between the increase in value in their respective lands and the general increase. For $A$ the figure would be $\$ 8$, for $B \$ 6$, for $C \$ 3$ per acre. But if only the land of $A$ had been taken, he would be liable to lose his $\$ 8$ per acre gain as an offset against the compensation due him for his land taken. The "fairness" principle would be violated because he would be worse off than $B$ solely because some of his land was taken and $B$ 's was not. The problem may be solved by applying the sole or unique benefit criterion. $A$ 's special benefit, therefore, is $\$ 2$ per acre because offsetting his benefits by this amount would leave him in at least as good a position as $B$. But suppose land is only taken from $B$ ? Has he enjoyed offsetting special benefits? If the relevant reference is $C$, the answer is yes; if $A$ the answer is no. One

${ }^{502}$ See State ex rel. State Highway Comm'n v. Pope, 228 Mo. App. 888, 74 S.W.2d 265 (1934).

${ }^{303}$ See, e.g., Petkus v. State Highway Comm'n, 24 Wis. 2d 643, 130 N.W.2d 253 (1964). 
way out of this dilemma is to include as relevant references all who have benefited above the "general level."

While case analysis offers no workable rules, counsel for the street use planner must be constantly probing the limits of "special benefits" to minimize the cost of implementing the plan. Because the ultimate goal of a traffic restriction program is to make the central business district a more attractive place to live and work, and because reaching that goal would necessarily increase CBD land values, benefits to owners whose land is partly taken or damaged are present. The courts must constantly be pressed to narrow the windfall profits of CBD owners by adopting less restrictive "special benefit" rules.

"Special benefits" has another usage which may help focus the costs of a CBD traffic restriction program on those most benefited by it. This usage is in the context of special assessments. Such assessments are a traditional method of financing localized improvements by placing a nondiscriminatory "tax" or assessment on property owners within a zone reasonably defined to include those who receive "special benefits." 504 The special assessment avoids the fairness problem of the offset because it affects all property owners benefited rather than only those whose property has been taken. Additionally, the charge for the special benefit is not limited to the offset for property taken or damaged but is fully distributed to the landowners. The special assessment technique permits costs to be assessed against a wider group because the formulas countenanced by the courts are particularly flexible. ${ }^{505}$

\section{CoNCLUSION}

The existence of the urban transportation problem presupposes the acceptance of cities in something approximating their present form. An analysis of the urban transportation problem must begin, therefore, with the relationship between cities and transportation.

${ }^{504}$ City of Baldwin Park v. Stoskus, 8 Cal. 3d 563, 503 P.2d 1333, 105 Cal. Rptr. 325 (1972).

${ }^{505}$ Benefits for assessment purposes may be ascertained by general formula. See, e.g., French v. Barber Asphalt Paving Co., 181 U.S. 324 (1901); Crampton v. City of Royal Oak, 362 Mich. 503, 108 N.W.2d 16 (1961) (presumption of validity attaches to legislative assessments; benefits measured by both present and future potential uses of property; burden of showing no benefit is on those assessed). 
Of the various transportation modes, the automobile is most destructive of the city. The automobile is responsible for most of the air pollution in cities. More importantly, the roadbed on which the automobile runs and the parking lot upon which it rests consume, in the eyes of many observers, an inordinate amount of urban land. The effort then is to find an alternative transportation mode which will provide equivalent service at a lower social cost. While rail rapid transit offers clear advantages over the automobile in terms of air pollution, its land use advantage is purchased only at the price of a loss of flexibility in both route and equipment. The inordinate cost of constructing new rapid transit systems makes them the least attractive alternative to the automobile. The more attractive public mode is the bus.

The federal urban mass transportation program is heavily weighted in favor of rail rapid transit. Aside from the apparent political advantages flowing from support of the latter systems as opposed to the bus, the explanation for the federal preference lies in the misconception that rail rapid transit will induce automobile commuters to leave their cars at home. Our analysis, however, indicates that of all the automobile users in urban areas, the commuter to work is the most difficult to lure from behind the steering wheel. The strategy must then be to supplement the carrot with the stick.

The stick strategy most likely to be effective in discouraging automobile commuting is planning that would preclude private automobile use on CBD streets. Of all the stick strategies possible, restricting street use offers the lowest cost, the greatest flexibility in implementation and alteration, the most equitable impact, and the highest predictable degree of success. Outweighing and supplementing these advantages is the fact that a land planning strategy is the only solution to the urban transportation problem that also promises a qualitative improvement in the urban environment. Only through total reorganization of the flow of traffic, not simply its reduction, can the CBD again become a pleasant place to work, shop, and live.

Implementation of the land planning solution will require a lawyer's skills. The land planning program involves more than simply closing streets. The lawyer can point out when a proposal will give rise to compensable claims and how the same end of traffic restriction might otherwise be achieved at a lower cost. $\mathrm{He}$ can alert planners to the possibility that a court might view a 
plan as a vacation and recommend steps to be taken to avoid such a determination. In general, the lawyer should assist his client in accomplishing the plan's objectives at the least economic, political, and social cost. 